Fuertes

QL 696

C4

$\mathrm{C} 77 \mathrm{x}$

1910

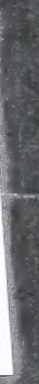

\title{
ORNITH
}

QL
696
C4
C77x
1910




\title{
U.S. DEPARTMENT OF AGRICULTURE
} BIOLOGICAI SURVEY -BULLETIN NO. 35

H: W. HENSHAW, Chief

\section{DISTRIBUTION AND MIGRATION OF NORTH AMERICAN SHOREBIRDS}

\author{
BY \\ WELTS W: COOKE \\ Assistant, Biological Survey
}

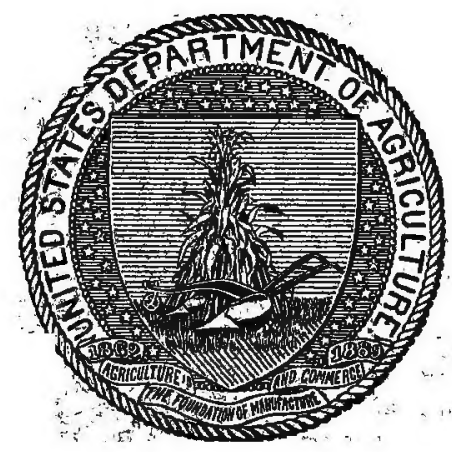

WASHINGTON

GOVIR NMET PRINTING OFEICE

1910 


\section{Cornell University Library}

The original of this book is in the Cornell University Library.

There are no known copyright restrictions in the United States on the use of the text. 
Issued October 6, 1910.

U. S. DEPARTMENT OF AGRICULTURE BIOLOGIGAL SURVEY - BDLLETIN NO. 35

H. W. HENSHAW, Chief

\section{DISTRIBUTION AND MIGRATION OF NORTH AMERICAN SHOREBIRDS}

BY

WELLS W. COOKE

Assistant, Biological Survey

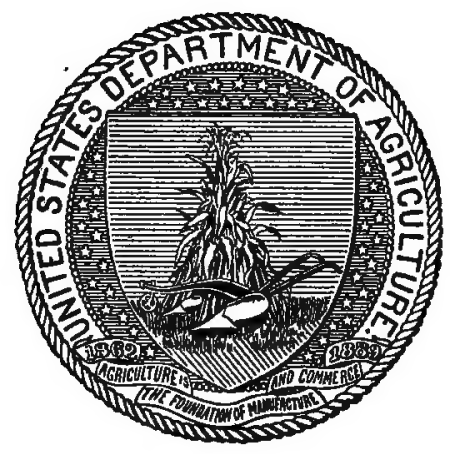

WASHINGTON

GOVERNMENT PRINTING OFFICE 


\section{LETTER OF TRANSMITTAL.}

\section{U. S. Department of Agriculture, \\ Biological Survey, Washington, D. C., June 2Q, 1910.}

SIR: I have the honor to transmit herewith, for publication as Bulletin No. 35 of the Biological Survey, a report on the Distribution and Migration of North American Shorebirds, by Wells W. Cooke, assistant, Biological Survey. Many species of shorebirds inhabit the United States or pass through our territory in migration. These birds possess considerable economic importance, and as other wild game like ducks, geese, and swans diminish in numbers their value for food and as a means for sport will increase. Large numbers are annually killed, and unless prompt measures are taken adequately to protect them some of the larger and more important kinds are likely to become extinct, especially in the region east of the Mississippi River. A knowledge of the summer and winter abodes of the several species and of the routes they take in migration is essential to intelligent legislation in their behalf, and, accordingly, all the known facts in regard to this part of their life history are here brought together.

Respectfully,

Hón. James Wilson,

Secretary of Agriculture.
H. W. Henshaw, Chief, Biological Survey. 


\section{CONTENTS.}

Introduction Page

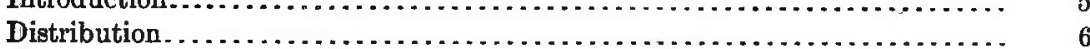

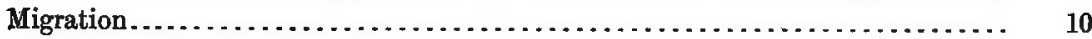

North American shorebirds....................................... 14

Red phalarope........................................... 14

Northęn phalarope.......................................... 16

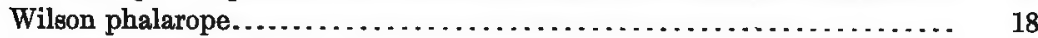

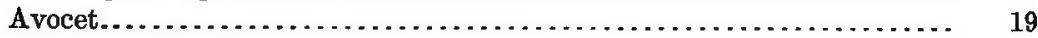

Black-necked stilt....................................... 20

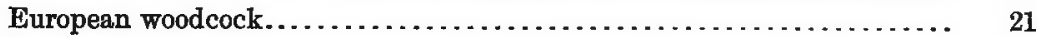

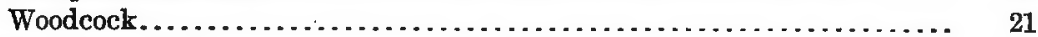

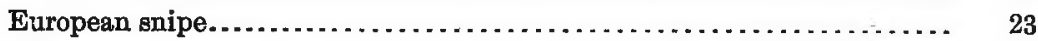

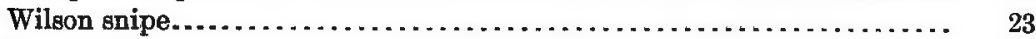

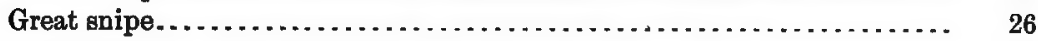

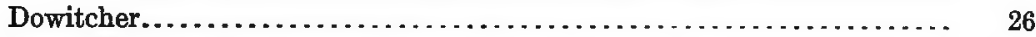

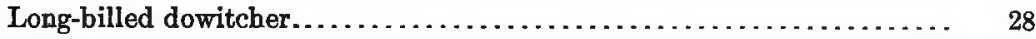

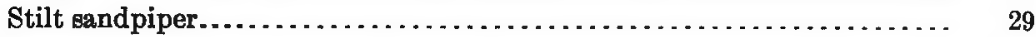

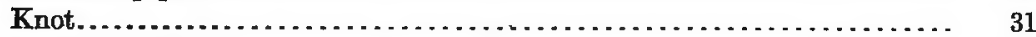

Purple sandpiper................................................. 33

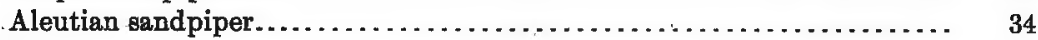

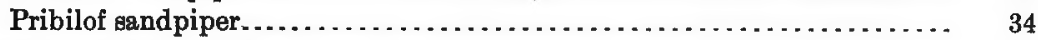

Sharp-tailed sandpiper....................................... 34

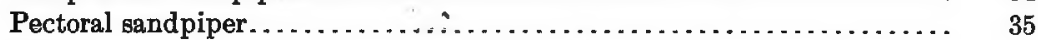

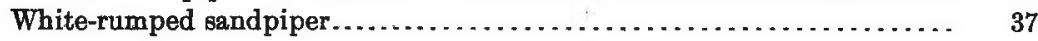

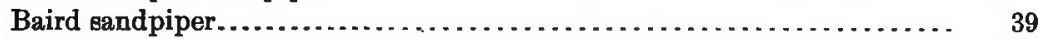

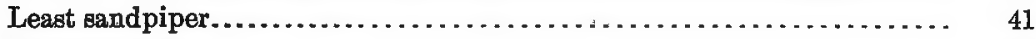

Long-toed stint............................................. 42

Cooper sandpiper.......................................... 43

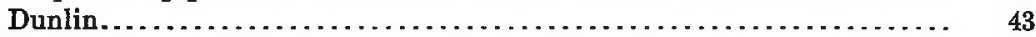

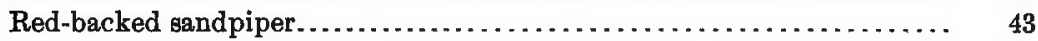

Curlew sandpiper........................................... 45

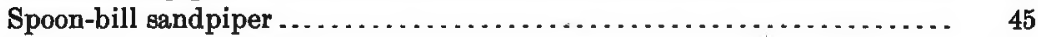

Semipalmated sandpiper..................................... 46

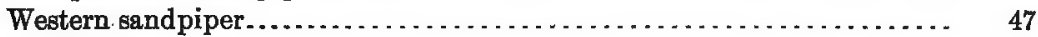

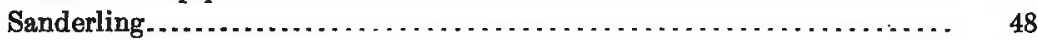

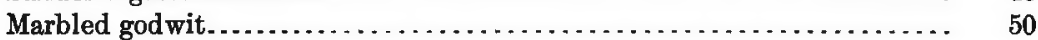

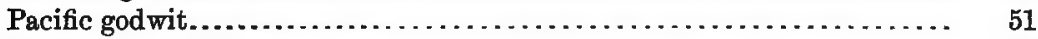

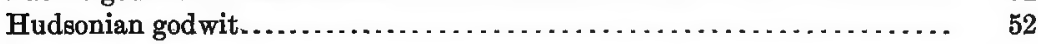

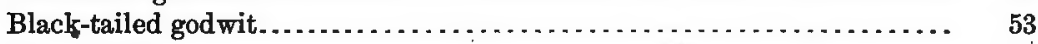

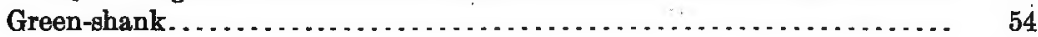

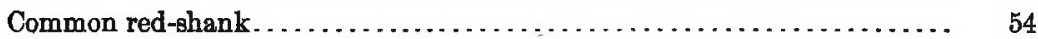

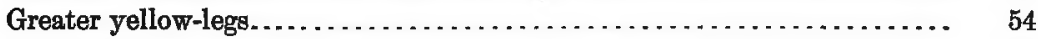

Yellow-lega............................................... 56

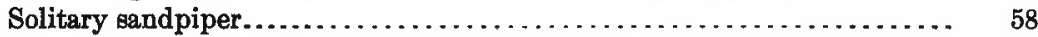

Western solitary sandpiper.............................. 60

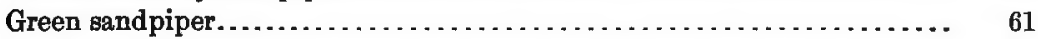

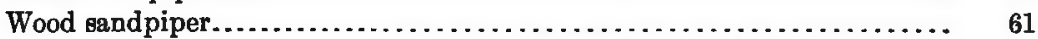

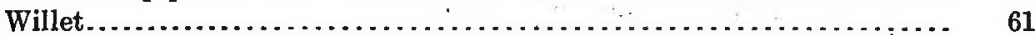


North American shorebirds-Continued. Page.

Western willet........................................ 62

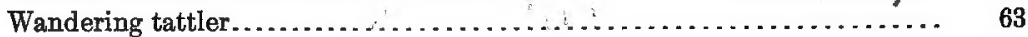

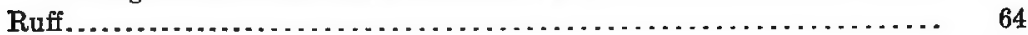

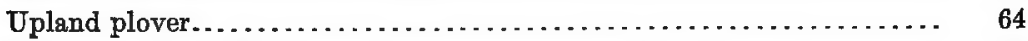

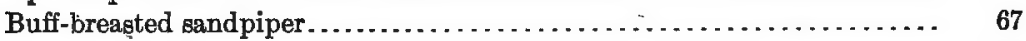

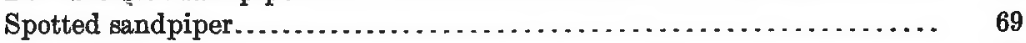

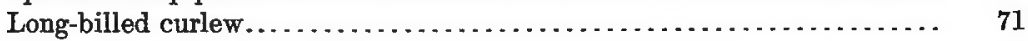

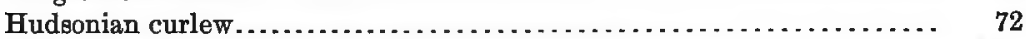

Eskimo curlew....................................... 74

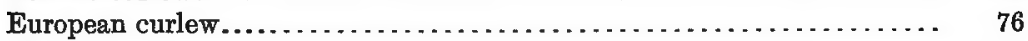

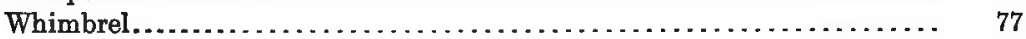

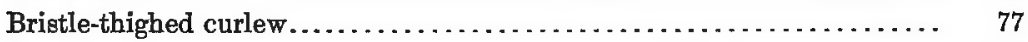

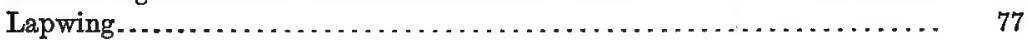

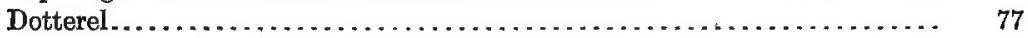

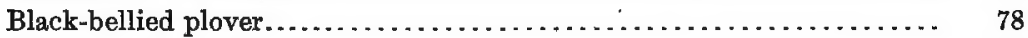

European golden plover..................................... 79

Golden plover.......................................... 80

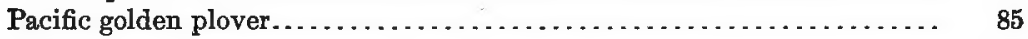

Killdeer.................................................. 85

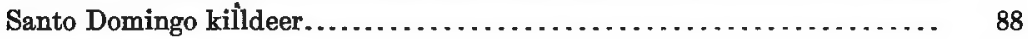

Semipalmated plover.................................... 88

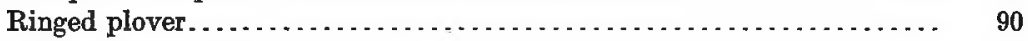

Little ringed plover......................................... 90.

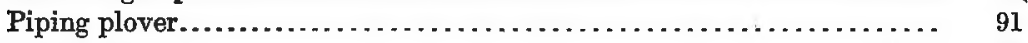

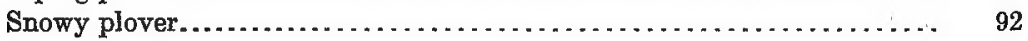

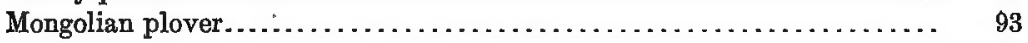

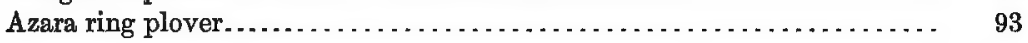

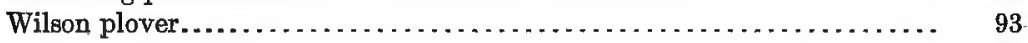

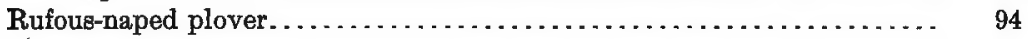

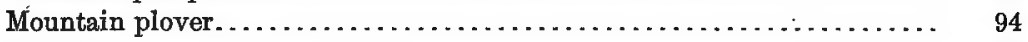

Surf bird...................................................... 95

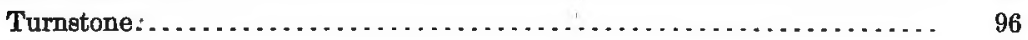

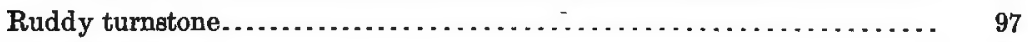

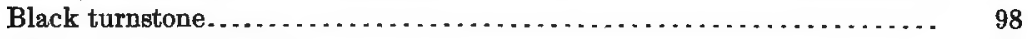

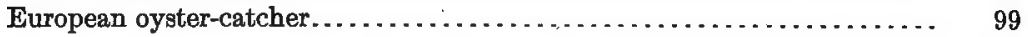

Oyster-catcher............................................. 99

Frazar oyster-catcher..................................... 99

Black oyster-catcher........................................ 100

Stone curlew.......................................... 100

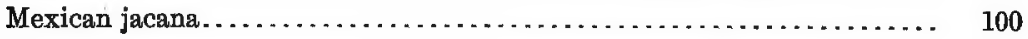

Black jacana.................................................. 100

Colombian jacana............................................ 100

\section{LIST OF ILLUSTRATIONS.}

Plate I. Yellow-legs (Totanus flavipes)................ Page.

II. Upland plover (Bartramia longicauda) . . . . . . . . . . . . . . . . . 64

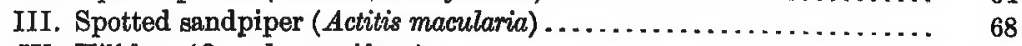

IV. Killdeer (Oxyechus vociferus)....................... 84 


\section{DISTRIBUTION AND MIGRATION OF NORTH AMERICAN SHOREBIRDS.}

\section{INTRODUCTION.}

Shorebirds form a valuable national resource, and it is the plain duty of the present generation to pass on to posterity this asset undiminished in value. Consistent and intelligent legislation in favor of any group of birds must be founded on extended, accurate information, and must include knowledge of the breeding and distribution of the birds-where they spend the summer, whither they retire in winter, and when and by what routes they migrate. The present bulletin supplies this needed information so far as it is now available.

Consideration of our shorebirds (Limicolæ) from an economic point of view is recent. The early settlers found ducks, geese, and swans swarming in certain sections of the United States, and grouse and turkeys very abundant. The size and toothsomeness of these birds made them important objects of pursuit for food, while the shorebirds were considered unworthy of notice. As the great flocks of ducks and geese along the Atlantic coast diminished in numbers, the attention of gunners, especially of market hunters, was turned to the shorebirds, then in countless numbers. A generation of constant harassment spring and fall has almost exterminated some of the larger species and has very greatly reduced even the smaller ones. The time has come when this indiscriminate slaughter must cease if the present remnant of the shorebirds is to be preserved.

The range of our shorebirds extends from ocean to ocean, so that all parts of the United States have an interest in their preservation. These birds feed naturally in the open country or along the open shore, where they are easily found and are constantly subject to attack. The prairies of the Mississippi Valley in past years formed the great highway of spring migration. Flock followed flock in almost endless succession across the prairies of Kansas, Nebraska, and the Dakotas, over a region that of late years has passed under the plow. As this area becomes more densely populated the shorebirds, once so abundant, are likely to become extinct unless active measures are taken for their preservation.

There are excellent reasons for protecting and preserving the shorebirds. Some of them, especially the several kinds of plovers, 
perform important service in destroying noxious insects. The flesh of many of them, even of the smaller kinds, has a high food value, and some of the larger species-the upland, golden, and black-bellied plovers, and the curlews-were in the times of their abundance important articles of diet. Their pursuit for sport, when they are shot over decoys, demands a high degree of skill, and is a favorite pastime of many hunters. Nor should the esthetic side of the question be ignored. The graceful forms and motions of these birds as they feed at the edge of the breakers are an interesting sight to thousands of seashore visitors. The silencing of their melodious calls would be a loss to every lover of nature. Finally, it may be said in their favor that not one of the shorebirds ever does any harm, while many have proved of great value to agriculture. Their accounts have only a credit side.

The shorebirds are among the most widely distributed of all birds. As far to the northward as man has found land shorebirds breed, while in winter they visit the tropical and Antarctic shores. The distances traversed in their migrations probably average greater than those of any other family, and the shorebirds probably exceed all others in the number of miles traveled in a single flight.

\section{DISTRIBUTION.}

The shorebirds are represented in North America by 76 species and 9 subspecies, a total of 85 recognized forms; but the following 7 of these do not range so far north as the United States:

Southern Species not Ranging North to the Untted States.

Rufous-naped plover (Ochthodromus wilsonius rufinuchus).

Stone curlew (Edicnemus bistriatus).

Colombian jacana (Parra melanopygia).

Black jacana (Parra nigra).

Cayenne lapwing (Hoploxypterus cayanus). Azara ring plover (Egialitis collaris).

Santo Domingo killdeer (Oxyechus vociferus torquatus).

There remain 78 species and subspecies that occur in the United States and northward, but 5 of these are found only in Greenland, as follows:

European Species Occurring in North Amerida only in Greenland.

European snipe (Gallinago gallinago).

Black-tailed godwit (Limosa limosa).

Whimbrel (Numenius phropus).

Golden plover (Charadrius apricarius). Oyster-catcher (Hæmatopus ostralegus).

Fifteen other species from the Eastern Hemisphere are known as stragglers on the mainland of North America:

Stragglers in North America from the Eastern Hemisphere.

European woodcock (Scolopax rusticola).

Great snipe (Gallinago media).

Long-toed stint ( $P$ isobia damacensis).

Dunlin (Pelidna alpina).

Curlew sandpiper (Erolia ferruginea).

Spoon-bill sandpiper (Eurynorhynchus pygmeus).

Green-shank (Glottis nebularia).
Red-shank (Totanus totanus).

Green sandpiper (Helodromas ocrophus).

Wood sandpiper (Rhyacophilus glareola).

Ruff (Pavoncella pugnax).

Lapwing (Vanellus vanellus).

Dotterel (Eudromias morinellus).

Little ringed plover (AEgialitis dubia).

Mongolian plover (AEgialitis mongola). 
Deducting these, there are 58 species of shorebirds that belong to the regular avifauna of North America north of Mexico. Not all of these, however, occur in the United States. The sharp-tailed sandpiper is a regular migrant through Alaska, but is not found elsewhere in North America. The Pacific godwit, bristle-thighed curlew, and Pacific golden plover breed in Alaska and migrate thence to Asia and the Pacific islands. The ringed plover breeds in northeastern North America and migrates to Europe. The turnstone breeds in both northeastern and northwestern Arctic America, but migrates to Europe, Asia, and the Pacific islands without coming regularly to the United States; while the Aleutian and the Pribilof sandpipers both breed and winter in Alaska. A further deduction of these 8 species leaves 50 species which regularly visit the United States during some part of the year.

The shorebirds as a group are far northern breeders. The majority of them breed in the region of the Arctic Circle, and several range north to the known limits of land. The majority do not breed so far south as the United States, and hence are known there only as migrants, or in the winter season.

Species that Breed Wholly North of the United Stateg.

Red phalarope (Phalaropus fulicarius).

Northern phalarope (Lobipes lobatus).

Dowitcher (Macrorhamphus griseus).

Long-billed dowitcher (Macrorhamphus griseus scolopaceus).

Stilt sandpiper (Micropalama himantopus).

Knot (Tringa canutus).

Purple sandpiper (Arquatella maritima).

Aleutian sandpiper (Arquatella maritima couesi).

Pribilof sandpiper (Arquatella maritima ptitocnemis).

Sharp-tailed sandpiper (Pisobia aurita).

Pectoral sandpiper (Pisobia maculata).

White-rumped sandpiper ( $P$ isobia fuscicollis).

Baird sandpiper (Pisobia bairdi).

Least sandpiper (Pisobia minutilla).

Red-backed sandpiper (Pelidna alpina sakhalina).

Semipalmated sandpiper (Ereunetes $p u$ sillus).

Western sandpiper (Ereunetes mauri).

Sanderling (Catidris leucophæa).
Pacific godwit (Limosa lapponica.baueri). Hudsonian godwit (Limosa hæmastica).

Greater yellow-lege (Totanus melanoleucus).

Yellow-legs (Totanus favipes).

Wandering tattler (Heteractitis incanus).

Buff-breasted sandpiper (Tryngites subruficollis).

Hudsonian curlew (Numenius hudsonicus).

Eskimo curlew (Numenius borealis).

Bristle-thighed curlew (Numenius tahitiensis).

Black-bellied plover (Squatarola squatarola).

Golden plover (Charadrius dominicus).

Pacific golden plover (Charadrius dominicus fulvus).

Semipalmated plover (Agialitis semipalmata).

Ringed plover (Egialitis hiaticula).

Surf bird (Aphriza virgata).

Turnstone (Arenaria interprès).

Ruddy turnstone (Arenaria interpres morinella).

Black turnstone (Arenaria melanocephala).

Species that Breed in Both the United States and Canada.

Wilson phalarope (Steganopus tricolor).

Avocet (Recurvirostra americana).

Woodcock (Philohela minor).

Wilson snipe (Gallinago delicata).

Marbled godwit (Limosa fedoa).

Solitary sandpiper (Helodromas solitarius).

Western solitary sandpiper (Helodromas salitarius cinnamomeus).

Willet (Catoptrophorus semipalmatus).
Western willet (Catoptrophorus semipalmatus inornatus).

Upland plover (Bartramia longicauda).

Spotted sandpiper (Actitis macularia).

Long-billed curlew (Numenius americanus).

Killdeer (Oxyechus vociferus).

Piping plover (Ágialitis meloda).

Black oyster-catcher (Hæmatopus bachmani). 
Species that do not Breed North of the United States, with Northern Limit of Breeding Range.

Black-necked stilt (Himantopus mexicanus), Oregon.

Snowy plover (Agralitis nivosa), Nevada.

Wilson plover (Ochthodromus wilsonius), Virginia.

Mountain plover (Podasocys montanus), Montana.

Species that Brefd Chiefly North of the Arctic Circle, with the Northernmost Latitude at Which the Species has been Observed in the Western HEMISPHERE.

Red phalarope (Phalaropus fulicarius), $82^{\circ}$.

Northern phalarope (Lobipes lobatus), $74^{\circ}$.

Long-billed dowitcher (Macrorhamphus griseus scolopaceus), $71^{\circ}$.

Stilt eandpiper (Micropalama himantopus), $69^{\circ}$.

Knot (Tringa canutus), $83^{\circ}$.

Purple sandpiper (Arquatella maritima), $74^{\circ}$.

Pectoral sandpiper (Pisobia maculata), $71^{\circ}$.

White-rumped sandpiper ( $P$ isobia fuscicollis), $69^{\circ}$.

Baird sandpiper ( $P$ isobia bairdi), $71^{\circ}$.

Least sandpiper ( isobia minutilla), $70^{\circ}$.

Red-backed sandpiper (Pelidna alpina sakhalina), $72^{\circ}$.

Semipalmated sandpiper (Ereunetes pusillus), $71^{\circ}$.

\section{Species that Breed in Both Eastern and Western Hemispheres.}

Red phalarope (Phalaropus fulicarius). Northern phalarope (Lobipes lobatus).

Knot (Tringa canutus).

Purple sandpiper (Arquatella maritima).

Sanderling (Catidris leucophæa).

Pacific godwit (Limosa lapponica baueri).

\section{Species that Winter in the United States and Southward.}

Avocet (Recurvirostra americana).

Black-necked stilt '(Himantopus mexicanus).

Woodcock (Philohela minor).

Wilson snipe (Gallinago delicata).

Dowitcher (Macrorhamphus griseus).

Long-billed dowitcher (Macrorhamphus griseus scolopaceus).

Purple sandpiper (Arquatella maritima).

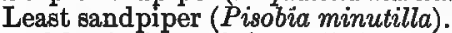

Red-backed sandpiper (Pelidna alpina sakhalina).

Semipalmated sandpiper (Ereunetes pusillus.)

Western sandpiper (Ereunetes mauri).

Sanderling (Calidris leucophæa).

Marbled godwit (Limosa fedoa).

Greater yellow-legs (Totanus melanoleucus.)

Yellow-legs (Totanus favipes).

Western willet (Catoptrophorus semipalmatus inornatus).
Sanderling (Calidris leucophæa), $82^{\circ}$.

Hudsonian godwit (Limosa hæmastica), $69^{\circ}$.

Buff-breasted sandpiper (Tryngites subruficollis), $71^{\circ}$.

Hudsonian curlew (Numenius hudsonicus), $69^{\circ}$.

Eskimo curlew (Numenius borealis), $69^{\circ}$.

Black-bellied plover (Squatarola squatarola), $71^{\circ}$.

Golden plover (Charadrius dominicus), $77^{\circ}$.

Pacific golden plover (Charadrius dominicus fulvus), $65^{\circ}$.

Semipalmated plover (Agialitis semipalmata), $75^{\circ}$.

Ringed plover (Agialitis hiaticula), $78^{\circ}$.

Turnstone (Arenaria interpres), 83․

Ruddy turnstone (Arenaria interpres morinella), $74^{\circ}$.

Black-bellied plover (Squatarola squatarola).

Pacific golden plover (Charadrius dominicus fulvus).

Ringed plover (Egialitis hiaticula).

Turnstone (Arenaria interpres).

Spotted sandpiper (Actitis macularia).

Long-billed curlew (Numenius americanus).

Black-bellied plover (Squatarola squatarola).

Killdeer (Oxyechus vociferus).

Semipalmated plover (Afgialitis semipalmata).

Piping plover (Agialitis meloda).

Snowy plover (Afgialitis nivosa).

Wilson plover (Ochthodromus wilsonius).

Mountain plover (Podasocys montanus).

Ruddy turnstone (Arenaria interpres morinella).

Black turnstone (Arenaria melanocephala). Oyster-catcher (Hæmatopus palliatus).

Frazar oyster-catcher (Hæmatopus frazari).

Black oyster-catcher (Hrmatopus bachmani).

Mexican jacana (Jacana spinosa). 


\section{Species that do not Winter North of South America.}

Red phalarope (Phalaropus fulicarius).

Northern phalarope (Lobipes lobatus).

Wilson phalarope (Steganopus tricolor).

Stilt sand piper (Micropalama himantopus).

Knot(Tringa canutus).

Pectoral sandpiper ( isobia maculata).

White-rumped sandpiper (Pisobia fuscicollis).

Baird sandpiper (Pisobia bairdi).

Hudsonian godwit (Limosa hæmastica).
Solitary sandpiper (Helodromas solitarius).

Western solitary sandpiper (Helodromas solitarius cinnamomeus).

Upland plover (Bartramia longicauda).

Buff-breasted sandpiper (Tryngites subruficollis).

Eskimo curlew (Numenius borealis).

Golden plover (Charadrius dominicus).

Surf bird (Aphriza virgata).

The three following species winter in the West Indies or Central America and southward, but are not found at this season in the United States: Willet (Catoptrophorus semipalmatus), wandering tattler (Heteractitis incanus), and Hudsonian curlew (Numenius hudsonicus). The purple sandpiper (Arquatella maritima) remains in winter as far north as Greenland and does not range south of the United States; while the Aleutian sandpiper (Arquatella maritima couesi) and the Pribilof sandpiper (Arquatella maritima ptilocnemis) do not occur in winter south of Alaska.

Species that Range South in Winter to South Amerioa, with the Southern Limit of the Winter Range.

Red phalarope (Phalaropus fulicarius), Falkland Islands.

Northern phalarope (Lobipes lobatus), Peru and probably farther.

Wilson phalarope (Steganopus tricolor), Falkland Islands.

Black-necked stilt (Himantopus mexicanus), Peru.

Dow i tcher (Macrorhamphus griseus), Brazil.

Long-billed dowitcher (Macrorhamphus griseus scolopaceus), probably Peru.

Stilt sandpiper (Micropalama. himantopus), Uruguay.

Knot (Tringa canutus), Tierra del Fuego.

Pectoral aandpiper (Pisobia maculata), Argentina.

White-rumped sandpiper ( $P$ isobia fuscicollis), Tierra del Fuego.

Baird sandpiper (Pisobia bairdi), Chile.

Least sandpiper (Pisobia minutilla), Chile.

Semipalmated sandpiper (Ereunetes pusillus), Patagonia.

Western sandpiper (Ereunetes mauri), Venezuela.

Sanderling (Calidris leucophæa), Argentina.

Hudsonian godwit (Limosa hæmastica), Strait of Magellan.

Greater yellow-legs (Totanus melanoleucus), Strait of Magellan.
Yellow-legs (Totanus flavipes), Strait of Magellan.

Solitary sand piper (Helodromas solitarius), Argentina.

Western solitary sandpiper (Helodromas solitarius cinnamomeus), not known.

Willet (Catoptrophorus semipalmatus), Peru.

Upland plover (Bartramia longicauda), Argentina.

Buff-breasted sandpiper (Tryngites subruficollis), Argentina.

Spotted sandpiper (Actitis macularia), Peru.

Hudsonian curlew (Numenius hudsonicus), Chile.

Eskimo curlew (Numenius borealis), Patagonia.

Black-bellied plover (Squatarola squatarola), Peru.

Golden plover (Charadrius dominicus), Argentina.

Semipalmated plover (Agialitis semipalmata), Argentina.

Snowy plover (Afgialitis nivosa), Chile.

Surf bird (Aphriza virgata), Chile.

Ruddy turnstone (Arenaria interpres morinella), Chile.

Oyster-catcher (Hæmatopus palliatus), Chile. 
Species that Occur in the United States Onty as Migrants, Breeding in the Far North and Wintering to the Southward.

Red phalarope (Phalaropus fulicarius).

Northern phalarope (Lobipes lobatus). Stilt sand piper (Micropalama himantopus).

Knot (Tringa canutus).

Pectoral sandpiper (Pisobia maculata).

White-rumped sandpiper ( $P$ isobia fuscicollis).

Baird sandpiper (Pisobia bairdi).
Hudsonian godwit (Limosa hæmastica).

Buff-breasted sandpiper (Tryngites subruficollis).

Hudsonian curlew (Numenius hudsonicus).

Eskimo curlew (Numenius borealis).

Golden plover (Charadrius dominicus).

Surf bird (Aphriza virgata).

SUMMARY.

Species that do not breed north of the United States................... 7

Species breeding in the United States and Canada.................... 15

Total species breeding in the United States............................. ${ }_{22}$

Species breeding wholly north of the United States...................... 36

Species breeding north of and wintering in the United States. . . . . . . . . . . . 15

Species breeding or wintering in the United States.................... 37

Species occuring in the United States as migrante only . . . . . . . . . . . . 13

Total species occurring in the United States. ....................... 50

Species occurring regularly in Arctic America, but not in the United States... 8

Total species occurring regularly in North America north of Mexico........ 58

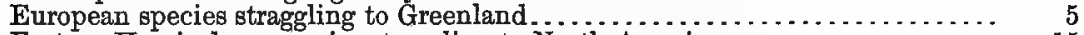

Eastern Hemisphere species straggling to North America. . . . . . . . . . . . 15

Southern species not ranging north to the United States. . . . . . . . . . . . . . 7

Total species and subspecies in North America....................... 85

\section{MIGRATION.}

The shorebirds as a group are among the most wide ranging of migrants. While a few, for example the jacanas, do not migrate at all, most shorebirds migrate more than a thousand miles each season, and many lengthen their journeys to 7,000 miles. The most wonderful feature of their migration is the enormous distance covered in a single flight. As explained in the account of the golden plover, many flocks of plover fly without resting from Nova Scotia to northern South America, a distance of about 2,500 miles. Many individuals of other species perform the same flight, notably the Eskimo curlew, while in the case of the Hudsonian godwit and the upland plover the principal place of departure in fall migration is the coast of the United States north of Virginia, and many of the flocks make stops in the Lesser Antilles on their way to South America.

That the same route is employed by other species is shown by the large number of shorebirds annually visiting the Bermudas. These islands lie about 800 miles off the coast of South Carolina and are in a nearly direct line from southern Nova Scotia to the Lesser Antilles. Years ago, when shorebirds were far more numerous than now, many flocks stopped at the Bermudas in fall migration. The most common species were the pectoral, white-rumped, least, and semipalmated sandpipers, the sanderling, greater yellow-legs, lesser yellow-legs, solitary sandpiper, spotted sandpiper, Hudsonian curlew, semipalmated plover, turnstone, and Wilson snipe. All of these came in sufficient numbers to show that their visits were not accidental, and evidently they had merely paused a few days on their journey to the Lesser Antilles. The killdeer appeared regularly in November and 
remained through the winter, but since this species searcely goes north of New England, the individuals wintering on the Bermudas must have visited the islands for the purpose of remaining there through the cold season. Specimens of eleven other species of shorebirds have been taken in the Bermudas. They are less common visitors, and most of these individuals were probably on their way across the ocean to the Lesser Antilles.

This route, however, is not followed by these species in their return in the spring, and there seems to be no evidence as yet that any species of shorebird migrates regularly in the spring across the ocean from the Lesser Antilles to the coast of New England or to eastern Canada. Indeed, shorebirds migrating north in spring through the Lesser Antilles are almost unknown.

Along the Atlantic coast shorebirds are many times more numerous in fall than in spring, while in the Mississippi Valley there is no such pronounced difference of numbers at the two seasons. This fact, taken in connection with the rarity of all species of shorebirds during the spring migration in the West Indies, where they are abundant fall visitors, seems to indicate that in the case of most of the species of shorebirds that migrate south in fall along the Atlantic coast some individuals pass northward in spring by way of the Mississippi Valley. The Eskimo curlew used to follow this route, as still do most of the golden plover. The statement applies also largely to the long-billed dowitcher, stilt, white-rumped, and semipalmated sandpipers, and the lesser yellow-legs. This elliptical migration route is in the case of most species not less than 6,000 miles in its north and south diameter, nor less than 2,000 miles east and west, while the winter home of the white-rumped sandpiper is 9,000 miles from its breeding grounds.

The Hawaiian Islands lie in the Pacific Ocean 2,000 miles from the nearest mainland to the eastward and more than 3,000 miles from the Asiatic coast. The nearest point of Alaska is about 2,000 miles north. Five species of shorebirds that summer in Alaska are found in the Hawaiian Islands during the winter season. They are the turnstone, Pacific golden plover, sanderling, bristle-thighed curlew, and wandering tattler. There is every reason to believe that these Hawaiian birds come from Alaska and that they make the 2,000-mile trip at a single flight. All of these species occur farther south in Oceania, but there seems to be no evidence that any of them use the Hawaiian Islands as a stopping place on the way to a more southern home. Apparently all the birds that fly to the Hawaiian Islands remain there through the winter, while the southern islands of Oceania are populated by individuals that have migrated along the Asiatic coast. It is remarkable that in the case of both the turnstone and the plover the first individuals to arrive on the Hawaiian Islands in the fall are in good condition or even fat, while the curlew and plover 
that reach the Lesser Antilles by a long flight over the Atlantic Ocean are reported as emaciated.

Shorebirds present some idiosyncrasies of migration that are worthy of mention. The sharp-tailed sandpiper (Pisobia aurita) breeds on the northern coast of Siberia, and in fall migration crosses to Alaska and then back again to Asia and by way of Japan and China reaches its winter home in Australia. The most eastern point of its range in Alaska-Norton Sound-is some 500 miles east of its summer home in Siberia. As the species is not known in Alaska in spring, its migration route is probably elliptical, and the northern route in spring is probably across the mainland of Asia.

Some individuals of the marbled godwit (Limosa fedoa) have a unique migration route. From their breeding grounds in North Dakota and Saskatchewan some of these birds formerly migrated almost directly east more than a thousand miles to the Atlantic coast, while others traveled a thousand miles due west to the coast of southern Alaska.

Some birds breed in the Western Hemisphere and winter in the Eastern. For example, the Pacific godwit (Limosa lapponica baueri) breeds on the western shores of Alaska, whence it passes by way of the Commander Islands, Japan, and China to its winter home in Australia. The bristle-thighed curlew (Numenius tahitiensis) follows a somewhat similar route. The wandering tattler (Heteractitis incanus) breeds in Alaska and some individuals pass in fall migration to Asia, Hawaii, and Oceania, while others continue down the American coast to the Galapagos.

A long migration route from the eastern side of North. America is followed by the ringed plover (AEgialitis hiaticula). Some individuals breed in Greenland and still farther west in Ellesmere Land and about Cumberland Sound, whence they pass east and southeast to the European coast and winter from the Mediterranean to southern Africa.

Both these last routes are used by the turnstone (Arenaria interpres). The individuals that breed in Greenland and Ellesmere Land migrate southeast to Europe and Africa, while those that breed in Alaska, even as far east as Point Barrow, migrate to the west and southwest to winter in Asia and Oceania.

Another migration route, probably unique, is that taken by the considerable numbers of the mountain plover (Podasocys montanus) that winter in the Sacramento Valley and elsewhere in California. The farthest west and north that the species is known to breed is Montana; hence whether the California wintering birds come from Montana or from the more southern districts, they apparently form an exception to the general rule that North American birds do not winter farther west than they breed.

Though many of the shorebirds breeding in North America winter in the southern part of South America, none of them breed in their 
winter home. Special attention needs to be called to this fact, because nearly a dozen species of this family-among which may be noted particularly the greater and lesser yellow-legs and the whiterumped sandpiper-have been reported as breeding near the southern end of South America. In no case has it been claimed that the eggs have been found, and all the records are based on the finding of young not fully grown or in most cases simply from the presence of individuals during the usual breeding season of local species. This latter reason is not even presumptive of breeding. Nearly a hundred species of North American birds escape the winter of the Northern Hemisphere by visiting South America, and they remain there through what is the breeding season of the resident species, but do not themselves undertake any household cares. It may be stated positively that none of the Limicolæ that breed north of the equator breed also in the southern part of their range.

Sptcies that are Regutar Migrants Spring and Fall on the atlantic and the Pacific Coasts and in the Interior.

American avocet (Recurvirostra ameri- $\mid$ Spotted sandpiper (Actitis macularia). cana).

Wilson snipe (Gallinago delicata).

Least sandpiper (Pisobia minutilla).

Greater yellow-legs (Totanus melanoleucus).

Black-bellied plover (Squatarola squatarola).

Killdeer (Oxyechus vociferus).

Semipalmated plover (Egialitis semipalmata).

Species that are Regular Migrants Spring and Fall on both the Atlantic and the Pactfic Coasts, but are Rare or Wanting in the Interior.

Red phalarope (Phalaropus.fulicarius).

Northern phalarope (Lobipes lobatus).

Red-backed sandpiper (Pelidna alpinasakhalina).

Sanderling (Calidris leucophra).

Hudsonian curlew (Numenius hudsonicus).

Ruddy turnstone (Arenaria interpres morinella).

Spectes that are Regular Migrants Spring and Fall on the Atlantic Coast and in the Interior, bUt are Rare or Wanting on the Pactfic Coaś'.

Woodcock (Philohela minor).

Knot (Tringa canutus).

Pectoral sandpiper (Pisobia maculata).

Solitary sandpiper (Helodromas solitarius).

Piping plover (Afgialitis meloda).

Species that are Regular Migrants Spring and Fall on the Pacific Cóast and in the Interior, but are Rare or Wanting on the Atrantic Coast.

Wilson phalarope (Steganopus tricolor).

Long-billed dowitcher (Macrorhamphus Long-billed curlew (Numenius americanus). griseus scolopaceus).

Western willet (Catoptrophorus semipalmatus inornatus).

Species that Occur in Mrgration Principally on the Pacific Coast.

Black-necked stilt (Bimantopus mexicanus).

Western sandpiper (Ereunetes mauri).

Western solitary sandpiper (Helodromas solitarius cinnamomeus).

Wandering tattler (Heteractitis incanus).

Snowy plover (Afgialitis nivosa).

Surf bird (Aphriza virgata).

Black turnstone (Arenaria melanocephala).

Black oyster-catcher (Hæmatopus bachmani).

Western Species that Come East in Migration to the Atrantic Coast.

Wilson phalarope (Steganopus̀ tricolor).

Long-billed dowitcher (Macrorhamphus griseus scolopaceus).

Baird sandpiper (Pisobia bairdi).

Western sandpiper (Ereunetes mauri). 
The data on the breeding and wintering of the shorebirds has been collated from all available printed sources, from the manuscript reports of the field naturalists of the Biological Survey, and from the specimens and catalogues of the United States National Museum. The dates of migration have been obtained principally from the migration schedules sent in by the several hundred observers in the United States and Canada, who for a quarter of a century have contributed to the Biological Survey spring and fall reports of their observations. It is a pleasure to testify to the earnest and conscientious efforts these observers have put forth for the solving of some of the phases of Nature's great migration problem and to return thanks to them for their painstaking labors.

\section{NORTH AMERICAN SHOREBIRDS.}

Red Phalarope. Phalaropus fulicarius (Linn.).

Breeding range. - The summer home of the red phalarope is circumpolar, and the species is known at this season from the whole northern coast and islands of America, Europe, and Asia, except a few regions, the most notable of which is the eastern coast of Greenland. It has been known to breed south to St. Michael, Alaska,

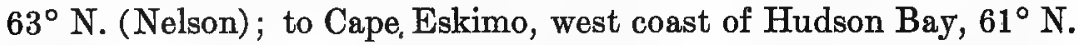
(Preble); Hudson Strait, $62^{\circ}$ N. (Turner); and to the south end of Greenland, $60^{\circ} \mathrm{N}$. (Schalow). It has been noted north to $83^{\circ} \mathrm{N}$, north of Spitzbergen (Sverdrup); $82^{\circ} 30^{\prime} \mathrm{N}$ : on Ellesmere Island (Feilden); Melville Island, $74^{\circ} 30^{\prime}$. N. (Parry); and Point Barrow, $71^{\circ} \mathrm{N}$. (Murdoch). It is especially abundant as a breeder along the coast and islands of Arctic America.

Winter range.-The Old World winter home of the species extends south to Morocco, India, China, and New Zealand. Knowledge of the winter range in the Western Hemisphere is very meager. The species has been noted in the extreme southern parts of South America on the Falkland Islands (Schalow), and Juan Fernandez (Sharpe); in November, when it may have been migrating, at Coquimbo, northern Chile (Salvin); on December 5 in Chile, locality not designated (Sharpe); specimens are recorded from Argentina and Colombia (Sharpe), without date or locality. The lack of records for . this species is remarkable. There seem to be no records whatever for the West Indies nor for the whole of middle America, except the western coast of Lower California, where the species is ordinarily a rare spring and fall migrant, but occasionally is seen in large flocks (Kaeding). Stragglers have been noted at Mount Pleasant, S. C., December 4, 1900 (Wayne); on the coast of northern Lower California, February 21 (Belding); and occasionally in winter at San Diego, Calif. (McGregor). 
Migration range.-Enormous flocks of the red phalarope have been noted on the Atlantic Ocean during both spring and fall migration. These flocks are common and regular around Newfoundland; become less common southward off the coast of Maine; and are rare off the coast of Massachusetts, except when driven inshore by storms. The red phalarope swims as lightly and easily as any duck, and during migration has been noted repeatedly gathering its food from the surface of the ocean. Indeed, it seems to have an aversion to land except during the breeding season. The migration route by which these flocks of red phalarope pass south after they leave Massachusetts is unknown. The species is known only as a rare straggler on the coast of the United States south of Long Island, and as already remarked is not recorded from the West Indies nor from the east coast of South America north of Argentina. On the Pacific coast the species is an abundant breeder in Alaska, and the flocks pass along the coast of California both spring and fall, after which they can no longer be traced. A few occur on the coast of Lower California, and the species is a rare straggler to the coast of Chile. The principal winter home of the thousands of birds reared each season in arctic America remains yet to be determined.

The red phalarope occurs as a rare straggler in the interior of the United States in migration, and has been recorded from Illinois, Indiana, Ohio, Michigan, Ontario, Wisconsin, Minnesota, Kansas, and Wyoming. The first and only record for Colorado is that of a single specimen taken by Edward A. Preble, of the Biological Survey, July 25, 1895, near Loveland.

Spring migration.- Some early flocks appeared off the coast of North Carolina the first week in April, 1896 (Thayer); most of the migration on the coast of Massachusetts occurs during May, especially May 20-30; the first appeared June 2, 1820, on Melville Island, latitude $74^{\circ} \mathrm{N}$. (Parry), and June 3, 1852 (Armstrong), near the same locality; on June 18, 1883, the first was seen at Fort Conger, Ellesmere Island, latitude $81^{\circ} 40^{\prime} \mathrm{N}$. (Greely); and on June 20, 1876, the species appeared 1 degree farther north on the same island (Feilden). Even considering the 1st of May as the time of arrival on the Massachusetts coast, which is probably too early, there are left only fifty days for the 3,000-mile trip from Massachusetts to Ellesmere Island, an average rate of migration of 60 miles per day, which is exceeded by very few species. In spring migration the red phalarope has been noted on the coast of California from April 3 to June 3 (Kaeding), and reached Point Barrow, Alaska, June 4, 1882, and May 30, 1883 (Murdoch).

Eggs have been taken in Greenland June 3-28 (Hagerup); near Fort Anderson June 27 (MacFarlane); and at 'St. Michael June 8 (Nelson). 
Fall migration.-The earliest fall birds are seen on the coast of California during July (Loomis); the larger flocks begin to appear late in August and pass south for the next three months. The last seen at Point Barrow, in 1882, was on October 10 (Murdoch). The species was abundant off the coast of Massachusetts August 4, 1877 (Kumlien); and has been noted on Long Island to the third week of November (Braislin).

Northern Phalarope. Lobipes lobatus (Linn.).

Breeding range.-The northern phalarope breeds in the arctic region of both hemispheres, but does not go quite so far north as the last species. It ranges from the Chuckchi Peninsula of Siberia eastward across the whole arctic coast of America to the eastern coast of Greenland. It breeds north to Upernivik, Greenland, $73^{\circ}$ N. (Kumlien); Melville Island, $74^{\circ} \mathrm{N}$. (Walker) ; Point Barrow, Alaska, $71^{\circ}$ N. (Murdoch); and Wrangel Island, Siberia, $72^{\circ} \mathrm{N}$. (Nelson). The main breeding ground lies farther south on the mainland of North America, especially in northern Mackenzie and western Alaska. It breeds south to Ungava Bay, about $59^{\circ} \mathrm{N}$. (Turner); near Rupert House, Ontario (Drexler); to near. York Factory, Keewatin, $57^{\circ} \mathrm{N}$. (Preble); Fort Anderson, Mackenzie, $68^{\circ} 35^{\prime}$ N. (MacFarlane); Pastolik, in the delta of the Yukon, Alaska, $63^{\circ} \mathrm{N}$. (Dall and Bannister); and to Kiska Island, near the west end of the Aleutians, $52^{\circ} \mathrm{N}$. (Dall). In the Eastern Hemisphere it is an abundant breeder from the limit of tree growth to the Arctic coast, and in eastern Siberia occasionally south to latitude $55^{\circ}$.

Winter range.-The winter home of the great flocks of northern phalaropes that breed in arctic America is unknown. The European and Siberian birds winter on the coast of Europe and south to Persia, India, China, and the Malay Archipelago. For the whole of the Atlantic coast of both North and South America there is not a single winter record. A solitary bird was noted at Tumbez, Peru, January 28 (Taczanowski); and the species has been recorded from Chorillos, Peru, without date (Berlepsch and Stolzmann). These are the only certain records for the whole of South America. This lack of winter land records suggests the possibility that both this species and the red phalarope spend the winter in midocean feeding and sleeping on the surface of the water.

Migration range.-The northern phalarope comes south along the eastern coast of North America, and is seen commonly, as far south as Nova Scotia. The flocks seem normally to strike south from Nova Scotia into midocean, but occasionally they are driven westward by storms and appear on the New England coast, sometimes by thousands. The birds are not rare south to Long Island, but farther south can be considered hardly more than stragglers, though recorded to South Carolina (Loomis). 
The northern phalarope is a regular though not common migrant throughout the interior of the United States, and has been recorded from almost every State north of the Ohio River and south to Kansas (Goss) and New Mexico (Henry). There is no record as yet for any of the Gulf States. The species is a common migrant on the Pacific coast of America, and is sometimes abundant south to the coast of central California. Farther south it is less common, though recorded from San Jose, Lower California, in the fall (Brewster), and from the west coast of Mexico in the spring (Nelson). The few noted at Duenas, Guatemala, in August and September (Salvin), and those at Desamparados, Costa Rica (Salvin and Godman), complete the record for Central America.

Spring migration.-The northern phalarope was noted in the Bermudas March 21-22, 1848 (Hurdis), and March 8, 1852 (Reid). This is almost two months earlier than the species usually appears on the New England and Long Island coasts. Six years' observations at Montauk Point Light gives May 13 as the mean date of spring arrival-earliest, April 30, 1898 (Scott). Almost all the dates for the coast of Massachusetts are in May. The species arrives at the northern limit of its range about the middle of June. Some late records on the Atlantic coast are: Near Charleston, S. C., June 3, 1903 (Wayne); Montauk Point, New York, June 3, 1894 (Scott); on the coast of Maine to the middle of June (Job).

The northern phalarope was common at Sihuatanejo, on the western coast of Mexico, April 9, 1903 (Nelson); it usually appears on the coast of California in early May, reaches the mouth of the Yukon the middle of May, and was noted in the Kowak Valley, Alaska, May 22, 1899 (Grinnell); Point Barrow, June 11, 1883 (Murdoch), and June 15, 1898 (Stone); Walker Bay, Prince Albert Land, June 15, 1852 (Greely). Individuals are occasionally seen on the California coast in summer, but these are nonbreeders.

Eggs have been taken near Rupert House, Ontario, June 18, 1860 (Drexler); near Fort Anderson, June 16, 1862 (MacFarlane); at Kiska Island, Aleutians, June 30, 1873 (Dall); St. Michael, Alaska, June 1-20 (Nelson); and Kowak Valley, Alaska, June 28, 1898 (Grinnell).

Fall migration.-Returning migrants appear on the coast of central California less than six weeks after the northbound flocks disappear, and are common by the end of July. The great flocks pass during August, are less common in September, and cease in October-latest, Monterey, October 24, 1896 (Loomis). The average date of fall arrival at Montauk Point, New York, is August 28-earliest, August 5, 1893, latest, October 22, 1888 (Scott). The last one noted at Point Barrow was seen August 17, 1898 (Stone), and the species usually disappears from the mouth of the Yukon the last of September.

52928 - Bull. $35-10-2$ 
Records of migration in the interior of North America are not numerous. In southwestem Saskatchewan the fall migration opened July 13,1906 , with the arrival of a large flock, and a few days later the birds were abundant. This is only four weeks later than the departure of the northbound migrants, which had been seen in the vicinity in 1905 from May 29 to June 15, and the following year as late as June 14 (Bent). A remarkable flight of northern phalaropes occurred near Terry, Mont., in 1899; during the last ten days of May the birds were exceedingly abundant (Cameron).

Wilson Phalarope. Steganopus tricolor Vieill.

Breeding range.--The northern Mississippi Valley and the adjacent parts of Canada form the principal summer home of the Wilson phalarope. It breeds regularly as far east as northwestern Indiana (Laké County; Butler) and the islands near Green Bay shore (Schoenebeck). Macoun records that a pair nested at Dunnville, Ontario, near the northeastern shore of Lake Erie. Thence the breeding range extends west through central lowa (Newton; Preston) and northern Colorado (Fort Collins; Cooke) to central California (Lake Tahoe; Bliss; and Las Banos; Mailliard). Instead of penetrating the Arctic regions, as do other phalaropes, this species finds the northern limit of its range in northern Manitoba (Lake Winnipeg; Thompson), central Saskatchewán (Osler; Colt), central Alberta (Edmonton; Macoun), northern Washington (Cheney; Johnson), and probably southern British Columbia.-

Winter range.- The few winter records for this species come from South America-from central Chile (Philippi) and central Argentina (Durnford) south to Patagonia (Durnford) and the Falkland Island (Sclater). There is a single record in fall migration for western Brazil (Pelzeln). and one in May for central Peru (Berlepsch and Stolzmann). Three specimens were collected January 19, 1890, at Corpus Christi, Tex. (Sennett), but these were apparently laggards, for the species is not usually seen in Texas after September.

Migration range.-During the fall migration individuals wander eastward to the Atlantic coast and have been noted from New Jersey to Montreal. There is also one May record for Massachusetts (Baird, Brewer, and Ridgway) and one June record for Maine (Smith). The species seems to be unknown on the Atlantic coast between New. Jersey and Argentina. The principal summer home is in western North America, and most of the species migrate south through Mexico and along both Mexican coasts, and then apparently cross directly to the west central coast of South America, since the species is unknown in Central America east of Guatemala and in South America north of Peru.

Spring migration.-The Wilson phalarope arrives in central Kansas on the average April 27, earliest April 23, 1885 (Kellogg); northern 
Colorado about May 1; Chicago, Ill., average May 6; Heron Lake, Minn., average May 11, earliest May 8, 1889 (Miller); Hallock, Minn., average May 14, earliest May 9, 1896 (Peabody); Reaburn, Manitoba, average May 21, earliest May 16, 1898 (Wemyss); Osler, Saskatchewan, May 19, 1893 (Colt).

The earliest eggs in northern Iowa are deposited about May 20 (Anderson); eggs nearly hatched have been found in southern Saskatchewan June 7 (Macoun); young just hatching, June 16, at Lake Tahoe, California (Bliss), and at the same stage June 22, at Fort Klamath, Oregon (Merrill).

Fall migration.-The Wilson phalarope moves southward so early that most have left the breeding grounds soon after the middle of August; the last seen at Lanesboro, Minn., in 1885, was on September 13 (Hroslef). The species continues passing through Mexico until October (Ferrari-Perez).

\section{Avocet. Recurvirostra americana Gmel.}

Breeding range.-The central western United States is the principal summer home of the avocet, but its breeding range extends north to central Wisconsin (Green Bay; Kumlien), southern Manitoba (Souris; Thompson), southern Saskatchewan (Osler; Colt), southern Mackenzie (Fort Rae; Ross), and central Oregon (Haines; Haines). It breeds south to northern Iowa (Hawarden; Anderson), northwestern Texas (Oberholser), southeastern New Mexico (Carlsbad; Bailey), and to Orange County, Calif. (Santa Ana; Grinnell). Many years ago this species was not rare on the Atlantic coast, and a few are known to have nested at Egg Harbor, N. J. (Giraud). At the present time it is a very rare visitor to any part of the Atlantic coast, and has scarcely been seen in New Jersey for the last twenty years. At various times in the past the avocet has been recorded along the coast from Florida (Cory) to southern New Brunswick (Chamberlain); one of the latest records is that of three birds seen September 13, 1896, at Ipswich Neck, Mass. (Kennard), and a single bird taken October 8, 1903, at St. Marys, Ga. (Arnow). The species occurs in the interior east of the Mississippi River, as a rare visitor from Louisiana (Audubon) to Ontario (Fleming), but is known to breed only in Wisconsin.

Winter range.-The avocet winters abundantly on the coast of Texas (Merrill) and in southern California (Newberry); sparingly through Chihuahua and Lower California and thence south to Guatemala (Salvin). During migration it has wandered a few times to Cuba (Gundlach), Jamaica (Gosse), and twice even to Barbados (Feilden).

Spring migration.-The month of April is the time of most activity in spring migration. By the latter part of this month the birds have reached South Dakota, and their average date of arrival at Great 
Falls, Mont., is April 24 (Williams). They have even been noted at Salt Lake, Utah, as early as March (Baird), and at Ash Meadows, Nev., March 15, 1891 (Fisher). They appeared April 28, 1908, at Okanagan Landing, B. C. (Brooks), May 14, 1892, at Indian Head, Saskatchewan (Macoun), and June 1, 1864, at Fort Resolution, Mackenzie (Preble).

Eggs have been taken at Santa Ana, Calif., as early as May 3 and as late as July 6 (Grinnell); eggs nearly ready to hatch were found at Hawarden, Iowa, June 2, 1900 (Anderson), and at Crane Lake, Saskatchewan, June 9, 1894 (Macoun).

Fall migration.- The southward movement begins so early that by the last of August the first migrants have reached southern Mexico. Individuals have been seen in Nebraska as late as.October 27, 1899 (Wolcott), and at Salt Lake, Utah, until a month later. Other late dates are: Cape Elizabeth, Me., November 5, 1878 (Brown); St. Mary Reservoir, Ohio, November 10, 1882 (Dawson); Oberlin, Ohio, November 4, 1907 (Jones); near New Orleans, La., November 12, 1889 (Beyer), and Johnsons Bayou, La., November 26, 1882 (specimen in United States National Museum).

Black-necked Stilt. Himantopus mexicanus (Müll.).

Breeding range.-The black-necked stilt is one of the very few shorebirds that breed in the United States and also in the Tropics. The breeding range extends north to Florida (Scott), Louisiana (Beyer), Texas (Merrill), southern Colorado (Henshaw), northern Utah (Allen), and central Oregon (Burns; Preble). More than half a century ago the species nested on Egg Island in Delaware Bay (Turnbull) and as late as 1881 still bred on the coast of South Carolina (Wayne). At the present time the bird is unknown along the whole Atlantic coast north of Florida, though formerly it has been noted locally to northern New England, and in September, 1880, one was seen at Mace Bay, New Brunswick (Chamberlain). In the interior of the United States the species is recorded as a straggler north to Ohio (Langdon), Michigan (Gibbs), Wisconsin (Hoy), Iowa (Rich), and Nebraska (Bruner, Wolcott, and Swenk), but is not known to breed east of the Rocky Mountains north of Texas. The southern limit of the breeding range is not yet well known. The species is a tolerably common resident of the entire West Indies and the whole northern coast of South America. It probably breeds south to central Peru and to the Lower Amazon. It breeds on the islands off the coast of Yucatan (Salvin), and probably on the coast of northeastern Mexico, and south to southern New Mexico (Carlsbad; Bailey) and southern California (Santa Ana; Grinnell). The early explorers of the West recorded it north to the Columbia River, but there are no definite breeding records so far north.

Winter range.-A few winter in southern Florida (Myers; Scott) and on the coasts of Louisiana (Beyer) and Texas (Corpus Christi; 
Rhoads), and from southern Sinaloa (Mazatlan; Nelson) and southern Lower California (La Paz; Ridgway), south throughout Central America and the West Indies to central Peru (Santa Lucia; Taczanowski) and the mouth of the Amazon (Sclater and Salvin). The species winters on the Galapagos Islands, and possibly a few remain to breed (Rothschild and Hartert).

Spring migration.-The slight northward migratory movements of this species occur principally in April. Some dates of arrival are: Titusville, Fla., March 11, 1905 (Worthington); Sioux City, Iowa, April 20, 1902 (Rich); Omaha, Nebr., April 20, 1895 (Bruner, Wolcott, and Swenk); Escondido, Calif., April 13, 1896, April 15, 1897 (Hatch); Fresno County, Calif., April 5, 1890 (Eaton); Stockton, Calif., April 13, 1878 (Belding).

Eggs have been taken in southern California from early May to August, and at Salt Lake, Utah, May 22 (Ridgway). At Fort Garland, Colo., the young were just hatched June 21, 1873 (Henshaw).

Fall migration.-The latest dates in Nebraska are in early October, and the species has been noted at Riverdale, Calif., as late as November 19, 1891 (Eaton).

\section{European Woodcock. Scolopax rusticola Linn.}

The European woodcock is widely distributed in Europe and western Asia. It breeds in northern Europe and northern Asia from beyond the Arctic Circle south to England, Silesia, the Alps, the Himalayas, and the mountains of Japan; also on the Azores, Madeira and Canary islands. It winters from the British Islands, southern Europe and China, to northern Africa, India, and Formosa; it wanders occasionally to eastern North America, and has occurred in Loudoun County, Va., in 1873 (Coues); Chester County, Pa., the end of November, 1886 (Stone); one was taken near Shrewsbury, N. J., December 6, 1859 (Lawrence); one, September, 1889, somewhere in New Jersey (Warren); one, probably of this species, near Newport, R. I. (Baird, Brewer, and Ridgway); one at Chambly, Quebec, November 11, 1882 (Wintle); and one at St. John, Newfoundland, January 9, 1862 (Sclater).

\section{Woodcock. Philohela minor (Gmel.).}

Breeding range.-The woodcock breeds locally throughout most of its range in the United States, at least south to Jacksonville, Fla. (Brewster), the coast of Louisiana (Beyer), and to Neosho Falls, in southern Kansas (Goss). It will probably be found breeding in some of the bottomlands of eastern Oklahoma. The breeding range extends northward to Pictou, Nova Scotia (McKinlay); Prince Edward Island (Dwight); Chatham, New Brunswick (Baxter); the city of Quebec (Dionne); Bracebridge, Ontario (Macoun); the northern peninsula of Michigan, at Koweenaw Point (Kneeland); extreme northeastern Minnesota, at Elbow Lake (Roberts and Benner); and to Winnipeg, 
Manitoba (Thompson). The species has wandered north to Newfoundland (Bennett); was noted the end of August, 1879, at York Factory, Keewatin (Bell); and early in August, 1892, on Black River, Saskatchewan (Tyrrell), at latitude $59^{\circ}$ - the most northern and also the most western record known. The woodcock has been seen several times in Colorado near Denver (Smith), though its regular range extends only to eastern South Dakota and eastern Kansas.

Winter range.-The woodcock remains in the north until driven away by frost, and the presence of unfrozen ground is the factor that determines the northern boundaries of its range through the winter. The larger part of the species winter in the Gulf States south at least to southern Florida (Myers; Scott) and to southern Texas (Victoria; Mitchell), but in Texas the species is very rare. Few woodcock winter north of latitude $37^{\circ}$, but these few are scattered at favorable localities over a wide area north to Long Island (Giraud), Grafton, Mass. (Mackay), and Vincennes, Ind. (Balmer). Woodcock have been taken several times in December at St. John, New Brunswick, but in each case they proved to be wounded birds (Gilbert). The species has been taken once in the Bermudas, in October, 1842 (Hurdis).

Spring migration.-Not only does the woodcock remain as far north as possible through the winter, but it also pushes northward in spring as soon as frost releases its feeding grounds. Average dates of spring arrival are: Renovo; Pa., March 22, earliest March 13, 1897 (Pierce); Long Island, New York, March 15, earliest March 10, 1898; central Connecticut, average of twelve years March 20, earliest February 24, 1891 ; eastern Massachusetts, average of eight years March 16, earliest February 22, 1902; southwestern Maine, March 29, earliest March 23, 1905; Halifax, Nova Scotia, March 25, earliest March 10, 1890 (Piers); St. John, New Brunswick, April 3, earliest March 21, 1898 (Banks) ; Pictou, Nova Scotia, April 12, earliest April 6, 1892 (McKinlay); city of Quebec, average of thirteeen years April 17, earliest April 4, 1890 (Dionne); Hillsboro, Iowa, March 17, earliest March 15, 1898 (Savage); Waterloo, Ind., March 11, earliest March 1, 1906 (Link); Oberlin, Ohio, March 21, earliest March 10, 1902 (Jones); Petersburg, Mich., March 17, earliest March 2, 1887 (Trombley); Chicago, Ill., March 26, earliest March 22, 1884 (Wentworth); southern Ontario, April 2, earliest March 26, 1901; Ottawa, Ontario, May 1, earliest April 20, 1890 (White); Quebec, Canada, earliest April 20, 1907 (Dionne).

One of the most pronounced peculiarities of the woodcock is the early date at which it breeds, especially in the Gulf States. Young a few days old were found January 29, 1890, at Covington, La. (Beyer), which requires that the eggs should have been deposited in December. Young a week old were noted at Jacksonville, Fla., March 10, 1877 (Brewster); young at Sourlake, Tex., March 22, 1905 (Gaut); young 
a week old at Falls Church, Va., April 18, 1897 (Riley); young just hatched, Norwich,Conn., April 5, 1888 (Rawson); young just hatched, Spearville, Ind., April 13, 1894 (Barnett); young, Oberlin, Ohio, April 19, 1901 (Baird); while eggs have been taken at Caper Island, South Carolina, February 13, 1903 (Wayne); Raleigh, N. C., March 9, 1892 (Brimley); Lower Cedar Point, Maryland, February 25, 1891 (Todd); Fallstown, Md., March 30, 1880 (Kirkwood); Lawrenceville, N. J., March 14, 1889 (Phillips); Rockland, Me., April 26, 1886 (Norris); Wheatland, Ind., March 14, 1882 (Ridgway); and at Vermilion, S. Dak., April 21, 1884 (Agersborg).

The average date of the last woodcock seen at Ottawa, Ontario, is October 19, latest October 23, 1885 (White); average southern Ontario October 21, latest November 6, 1889; usually leave Montreal, Canada, about October 20, but were seen in 1880 to December 16 (Wintle); St. John, New Brunswick, average date of the last seen November 10, latest November 13, 1888 (Banks); Halifax, Nova Scotia, average November 6, latest December 4, 1895 (Piers); southwestern Maine, averagė of nine years October 22, latest November 23,1900 .

European Snipe. Gallinago gallinago (Linn.).

The European snipe is an Old World species breeding in Iceland and throughout northern Europe and Siberia and south to the Alps, southern Russia, and Turkestan. It winters south to northern Africa and to China, Formosa, and the Philippines. It has been taken twice in the Bermudas-December 24 and 29, 1847 (Reid), and three times in Greenland-at Nanortalik, September 6, 1840; at Fiskenaes, October, 1845, both on the west coast of Greenland (Winge); and the third instance was May 29, 1902, at Angmagsalik, on the eastern coast (Helms). A specimen in the British Museum is marked as having come from Canada, but nothing is known of its history.

\section{Wilson Snipe. Gallinago delicata (Ord).}

Breeding range.-The northern limit of the breeding range of the Wilson snipe extends from Newfoundland (Reeks) and northern Ungava (near Fort Chimo; Turner) to northern Mackenzie (Dease River; Hanbury) and (Fort Anderson; MacFarlane), northern Yukon (La Pierre House; Catalogue United States National Museum), and northwestern Alaska (Kowak River; Grinnell), apparently following closely the limit of trees. Snipe have been noted a few times on the west coast of Greenland (Winge), but there is nothing to prove that they breed in that country. The species breeds south to New Jersey (Trenton; Abbott), northern Indiana (Davis Station; Deane), northern Illinois (Waukegon; Nelson), northern Iowa; (Union Slough, Kossuth County; Anderson), southern Colorado (San Juan County; Drew), northern Nevada (Ridgway), and northern California (Eagle Lake; catalogue egg collection, United States National Museum). 
Winter range:-During the winter season some Wilson snipe leave the United States and pass even to northern South America, on the east side to Rio Janeiro (Pelzeln) and on the west to Medellin, Colombia (Sclater and Salvin). A few winter in the Lesser Antilles and many in Jamaica, Cuba, and the Bahamas. The species is common in Mexico and Guatemala, less common in the remainder of Central America. A large part of the species winters in the southern United States, where it was formerly enormously abundant. No exact limit can be given to the northern range in winter. The Wilson snipe can not live where the ground is frozen. Hence the normal northern winter limit would extend from North Carolina through Arkansas to New Mexico and on the Pacific slope to northern California. But many snipe pass the winter much north of the zone of frozen ground, feeding about streams or springs. A few can be found almost every winter on Cape Cod, Massachusetts (Mackay), and a pair were seen during. January and February, 1896, as far north even as Wolfville, Nova Scotia (Tufts). From the Mississippi Valley snipe are reported as wintering north to northern Illinois and northern Nebraska (Bruner, Wolcott, and Swenk), while in the Rocky Mountains of Colorado at 8,000 feet near Sweetwater Lake, the presence of warm springs has enabled them to remain the entire winter, though the air temperature fell to $-30^{\circ} \mathrm{F}$. (Gilmore). They have been known also to winter in northern Montana (Coubeaux) and northern Washington (Snyder). A few snipe appear almost every fall in the Bermuda Islands (Jardine) and sometimes remain through the winter, though usually they are rare in spring.

Spring migration.-A series of nearly twenty years of observations near Alexandria, Va., gives the average date of arrival as March 8, with the earliest February 17, 1897 (Greenwood); the species is most common the last week in March. The average date of arrival in central New Jersey is March 22, earliest March 4, 1877. Some other dates of arrival are: Central Connecticut, average March 23, earliest March 18, 1894; eastern Massachusetts, average April 2, earliest March 21, 1887; southwestern Maine, average April 27, earliest April 14, 1897; Scotch Lake, New Brunswick, earliest April 5, 1907 (Moore); Pictou, Nova Scotia, average April 19, earliest April 11, 1889 (Mackinlay); city of Quebec, average April 23, earliest April 18, 1899 (Dionne).

The movements in the Mississippi Valley are at closely corresponding dates: Central Missouri, average date of arrival March 13; earliest February 17, 1897; Oberlin, Ohio, average March 28, earliest March 19, 1897 (Jones); Chicago, Ill., average April 3, earliest March 17, 1894 (Blackwelder); southern Michigan, average April 3, earliest March 21, 1893; southern Ontario, average April 15, earliest April 1, 1900; Ottawa, Ontario, average April 26, earliest April 12, 1902 
(White); Keokuk, Iowa, average March 23, earliest March 13, 1900 (Currier); central Iowa, average March 22, earliest March 11, 1897; southern Wisconsin, average March 30, earliest March 18, 1894; Heron Lake, Minn., average April 5, earliest April 1, 1888 (Miller); central South Dakota, average April 11, earliest April 7, 1890; Aweme, Manitoba, average April 24, earliest April 18, 1896 (Criddle); central Montana, average April 4, earliest March 27, 1894; Rathdrum, Idaho, average April 14, earliest April 8, 1899 (Danby); Okanagan Landing, British Columbia, April 8, 1907 (Brooks); Bulyea, Alberta, April 27, 1904 (Huck); near Fort Providence, Mackenzie, May 2, 1904, and May 1, 1905 (Jones); Fort Simpson, Mackenzie, May 10, 1904 (Preble); Nushagak, Alașka, April 25, 1882 (McKay); Fort Reliance, Yukon, May 2 (Sharpe); Fort Kenai, Alaska, May 5, 1869 (Bischoff); Nulato, Alaska, May 21, 1868 (Dall); Kowak River, Alaska, May 22, 1899 (Grinnell).

In southern Louisiana the average date of departure is April 19, latest April 30, 1887; Raleigh, N. C., average April 26, latest April 28, 1898 (Brimley); central Nebraska, average April 27, latest May 18, 1899; Chicago, Ill, average May 4, latest May 6, 1904 (Dearborn); Oberlin, Ohio, average May 5, latest May 16, 1904 (Jones). Some late dates of the last seen are: San Jose, Costa Rica, February 16, 1890 (Cherrie); Gainesville, Fla., April 15, 1887 (Chapman); Lake Ellis, N. C., May 9, 1906 (Brimley); Washington, D. C., May 4, 1900 (Preble); Bay St. Louis, Miss., May 10, 1902 (Allison); Dallas, Tex., May 1, 1898 (Mayer); Long Pine, Nebr., May 18, 1899 (Bates).

Eggs have been taken at Meadville, Pa., May 13, 1875 (Huidekoper); young about two days old at Trenton, N. J., May 26, 1876 (Abbott); eggs at Branchport, N. Y., May 20, 1896 (Stone); near Waukegan, Ill., April 24, 1896 (Deane); Davis Station, Ind., April 24, 1898 (Deane); Pewaukee, Wis., May 12, 1871 (Goss); Elk River, Minn., May 24, 1884 (Bailey); Minneapolis, Minn., May 14, 1887 (Cantwell); American Fork, Utah, April 29 (Johnson); Fort Klamath, Oreg., May 20, 1883 (Bendire); Yukon River, Alaska, May 28, 1861; Fort Resolution, Mackenzie, May 30, 1864 (Lockhart); Shumagin Islands, Alaska, June, 1895 (Call).

Few of the shorebirds suffer so much from spring shooting as the Wilson snipe. All winter long in the swamps of the southern States it is persecuted by hunters, and as it moves northward it meets a fusillade throughout its whole course. In the central parts of the South shooting is at its height early in March, and just south of the breeding range the bulk of the birds pass early in April.

Fall migration.-.July birds south of the breeding grounds are very rare, though they have been noted at Bay St. Louis, Miss., on the very early date of July 29, 1901 (Allison). Some dates of arrival 
in the fall are: Washington, D. C., August 30, 1894 (Richmond); Frogmore, S. C., September 16, 1885 (Hoxie); northern Florida, average September 26, earliest September 20, 1904 (Williams); southern Louisiana, average August 29, earliest August 25, 1901 (Ballowe); Lincoln, Nebr., August 7, 1900 (Wolcott); San Bernardino River, Sonora, August 19, 1893 (Mearns); San Jose del Cabo, Lower California, August 28, 1887 (Brewster); San Jose, Costa Rica, October 9, 1889 (Cherrie;) Bermudas, September 13 (Reid); Barbados, West Indies, October 11, 1886 (Manning). The hunter near Newport, R. I., secured scarcely a third as many snipe in the fall as in the spring-466 birds in the eight years; earliest July 30, 1870, latest November 14, 1871. The average dates were August 19 to October 27 (Sturtevant).

Some dates of the last seen are: Near Jasper House, Alberta, September 13, 1896 (Loring); Aweme, Manitoba, average October 11, latest Noviember 7, 1907 (Criddle); Lanesboro, Minn., October 31, 1887 (Hroslef); Keokuk, Iowa, average November 23, latest November 28, 1889 (Currier); Oberlin, Ohio, latest November 22, 1890 (Jones); Ottawa, Ontario, average November 2, latest November 18, 1900 (White); Chicago, Ill., average October 31, latest November 13, 1885 (Holmes); St. John, New Brunswick, November 5, 1889 (Banks); Halifax, Nova Scotia, average November 23, latest December 3, 1894 (Piers); southwestern Maine, average October 21, latest November 8, 1873; Montreal, Canada, average October 30, latest November 13, 1897 (Wintle).

\section{Great Snipe. Gallinago media (Latham).}

The great snipe is a species of wide distribution in the Eastern Hemisphere. Its breeding range extends from the Scandinavian Peninsula to the Yenisei River of Siberia and from Prussia north to at least $71^{\circ}$ north latitude. The winter home is from the Mediterranean to South Africa, and during its migration the species occurs from Great Britain to Persia.

The only record for the Western Hemisphere is that of a skin presented by the Hudson's Bay Company to the British Museum (Sharpe). There is no reason for doubting that the specimen was taken in Canada, but no definite locality can be assigned.

Dowitcher. Macrorhamphus griseus (Gmel.).

Breeding range.-The nest and eggs of the dowitcher are not yet known to science, nor has the species been seen in summer at any place where it was probably breeding. The dowitcher is a common migrant on the coasts of New Jersey, New York, Rhode Island, and Massachusetts, and in fall is sometimes very abundant. Farther north its numbers decrease: New Hampshire, tolerably common in fall, no spring records; Maine, tolerably common spring and fall; Quebec, rare migrant; New Brunswick, no records; Nova Scotia, 
once (Sharpe); Prince Edward Island, once; Ungava, a few in August, 1860, at Henley Harbor (Coues), one June 10, 1863, at Fort Chimo (Turner). North of Ungava, the only record is that of a single accidental occurrence at Fiskenaes, Greenland (Reinhardt). Evidently the dowitcher does not breed in any numbers on the eastern coast of Ungava. The probability that it does not breed there at all is strengthened by the fact that several first class observers, who during the fall migration were in the Gulf of St. Lawrence, did not see any of the birds. It undoubtedly does not go into northeastern Keewatin and the islands of the Province of Franklin, for it is not reported by the various expeditions that have traveled and wintered in those districts, while the specimens taken on the west coast of Hudson Bay belong to the form called scolopaceus. The only district left for the breeding ground is the interior of Ungava and the eastern shore of Hudson Bay.

Winter range.--The dowitcher ranges south in winter through the West Indies to the northern coast of South America and to the Amazon River (Sharpe). It remains at least as far north as northern Florida (Worthington) and probably a few as far west on the Gulf coast as Louisiana.

Spring migration.-The first one seen in 1890 at Darien, Ga., was on March 20 (Worthington); the average date of arrival on the southern coast of South Carolina is March 23, earliest March 17, 1885 (Hoxie); central North Carolina, average April 30; Pea and Bodie Islands, North Carolina, April 27, 1905 (Bishop); Long Beach, New Jersey, May 13, 1877 (Scott).

The species is rare west of the Allegheny Mountains, but a few specimens have been reported: Near Chicago, Ill., May 6, 1893 (Woodruff); Toronto, Ontario, not common May 16-31. This last locality seems to be about as far west as the dowitcher occurs regularly, though formerly it probably ranged west to Lake Michigan.

The species is not uncommon on the coast of Florida throughout the summer, but the individuals remaining so far south do not assume the breeding plumage (Scott). Migrants are common in Florida until the last week in May, and on the coast farther north the last leave for the breeding grounds about the first of June (Scott).

Fall migration.-The first migrants appear on the New England coast early in July: Edgartown, Mass., July 4, 1891 (Worth); near Newport, R. I., July 7, 1871 (Sturtevant); Long Beach, New Jersey, July 6, 1877 (Scott); Bone Island, Virginia, July 14, 1880 (Ridgway); Erie, Pa., July 19, 1892 (Todd); Pea and Bodie islands, North Carolina, July 7, 1904 (Bishop); Barbados, West Indies, August 24, 1888 (Feilden). A market hunter near Newport, R. I., shot 1,058 dowitchers during 1867-1874-extreme dates July 7, 1871, and October 20, 1870 , and average date of arrival July 17. (Sturtevant). Some dates 
of the last seen are: Henley Harbor, Ungava, August 21, 1860 (Coues); Montreal, Canada, September 27, 1892 (Wintle); Toronto, Ontario, September 15, 1889 (Fleming).

Iong-billed Dowitcher. Macrorhamphus griseus scolopaceus (Say).

Breeding range.-The long-billed dowitcher was found as a fairly common breeder in the Anderson River region, Mackenzie (MacFarlane), and breeds thence west along the Arctic coast to Point Barrow, Alaska (Murdoch), though not commonly. It is an abundant breeder at the mouth of the Yukon and on the shores of Norton Sound (Nelson). The species is known from the northern coast of eastern Siberia (Palmen), but as yet has not been found there breeding.

Winter range.-The principal winter home seems to be the shores of the Gulf of Mexico; the species is common as far east as the Gulf coast of Florida (Scott), and a few pass on to Cuba (Lawrence). It is common in Mexico and Guatemala, has been recorded as far south as Costa Rica (Frantzius), and it is probably this form that occurs in Panama (Lawrence).

Some form of the dowitcher occurs on the coast of Ecuador (Salvadori and Festa) and in Peru as far south as Tumbez (Taczanowski), but whether the eastern or western form has not yet been ascertained.

Migration range.-There is a decided easterly fall migration which brings quite a number of long-billed dowitchers to the Atlantic coast of the United States. They are fairly common from Long Island southward, and a few have been taken on the coasts of Rhode Island (Howe and Sturterant) and Massachusetts (Brewer); and one, August 12, 1891, at Hamilton, Ontario (Fleming). This is the form common in the Mississippi Valley and it is also more common than griseus, at least as far east as Ohio. There is one record of its accidental occurrence in Japan (specimen in United States National Museum).

Spring migration.-The long-billed dowitcher is only a straggler in spring on the Atlantic coast, but has been recorded at Washingtion, D. C., in April, 1884 (Smith and Palmer); Cape May, N. J., May, 1848 (specimen in United States National Museum); while on Long Island, New York, a very early individual was seen March 20 (Lawrence). The species normally reaches northern Indiana and northern Illinois late in April, but one was taken in 1889 at English Lake, Indiana, on the early date of March 11 (Butler). It was enormously abundant along the west shores of Lake Michigan in the early days of the settlement of the country, but of late years has become quite rare. Some dates of arrival farther west are: Fort Brown, Tex., March 27, 1853 (Cassin); Corpus Christi, Tex., March 24, 1889 (Sennett); Lawrence, Kans., April 19, 1873 (Snow); Omaha, Nebr., April 28, 1856 (Cassin); Cheyenne, Wyo., May 3, 1889 (Bond); Fort Kenai, Alaska, May 4, 1869 (Osgood); St. Michael, Alaska, May 18, 1877 (specimen in Sennett collection); Fort Anderson; 
Mackenzie, May 28, 1865 (MacFarlane); Point Barrow, Alaska, June 19, 1882 (Murdoch).

Eggs were taken at St. Michael, Alaska, May 23, 1880 (Nelson); near Fort Anderson, Mackenzie, June 21, 1864, and June 15, 1865 (MacFarlane); incubating birds were taken at Point Barrow, Alaska, June 28, 1883 (Murdoch).

Fall migration.-Southward-bound migrants were abundant July 31, 1900, on the west shore of Hudson Bay near Fort Churchill (Preble), and this must have been nearly the last of the migration, for none were seen after three days later. By this date the earliest migrants were already far south, as shown by the following dates of arrival: Fort Kanai, Alaska, July 20, 1869 (Osgood); Tulare Lake, Calif., July 8, 1907 (Goldman); Hay Creek, Saskatchewan, July 3, 1906 (Bent); Denver, Colo., July 24, 1873 (Henshaw); Long Island, New York; July 23, 1884 (Dutcher); Pea and Bodie islands, North Carolina, July 7, 1904 (Bishop); San Mateo, Oaxaca, August 12, 1869 (specimen in United States National Museum).

The last were seen at Point Barrow, Alaska, August 17, 1882 (Murdoch), and August 26, 1897 (Stone); Chilliwack, British Columbia, October 29, 1888 (Brooks); Hutton Lake, Wyoming, October 14, 1899 (Knight); Mimbres, Ariz., October 22, 1873 (Henshaw); Souris River, North Dakota, October 1, 1873 (Coues); Lincoln, Nebr., October 20, 1900 (Wolcott); Long Island, New York, October 15, 1884 (Lawrence).

Stilt Sandpiper. Micropalama himantopus (Bonap.).

Breeding range.-Information concerning the nesting of the stilt sandpiper is very meager. Several sets of eggs and some young birds were taken at Franklin Bay on the Arctic coast of Mackenzie and one nest was found at Rendezvous Lake, a few miles back from the coast (MacFarlane). A Biological Survey party found young of the year (probably migrants) July 19, 1900, near York Factory, Keewatin, and noted old birds August 12 near Cape Eskimo (Preble). The young were probably hatched somewhere on the Barren Grounds north of York Factory. The record from these regions seems to be the only data so far obtained bearing on the summer home of the species. It is probably safe to say that the breeding range extends along the Arctic coast and the adjoining tundras from near the mouth of the Mackenzie to the tree limit on the western shores of Hudson Bay.

Winter range.-If the winter home is to be determined solely by specimens noted or taken in winter, then it must be said that the winter home of the stilt sandpiper is unknown; for there seem to be only two records of the species anywhere for the months of November, December, and January. One of these is in Mexico (Ferrari-Perez) and the other in Texas (Sennett), and probably both were accidental 
occurrences. This is one of the rarer sandpipers and the total number of individuals is not great. The species is apparently most common on the Atlantic coast, while a smaller number occur around the Great Lakes and along the eastern edge of the Great Plains in the line leading to the coast of southern Texas. The winter home is therefore to be sought in a southerly direction from the eastern United States. The total records for the whole of Central America are only three, one each in Guatemala (Sclater and Salvin), Nicaragua (Sharpe), and Costa Rica (Zeledon); while the species is recorded as a tolerably common migrant in each of the Greater Antilles and in six islands of the Lesser, but as more common in the Lesser than the Greater Antilles. This latter fact indicates that the principal winter home lies along the Atlantic coast of South America, although records to substantiate this supposition are lacking. The South American records are as follows: Cienega, Colombia, September 13 (Allen); Barbahoyo (Sclater) and Vinces (Salvadori and Festa), Ecuador, each in September; Yquitos, Peru, September and August (Sharpe); Chorillos, Peru (Taczanowski); Nauta, Peru, September, October, March, and April (Sclater and Salvin); Falls of the Madeira, Bolivia, October (Allen); Ilha Grande, Brazil, August (Sharpe), and Matto Grosso, Brazil, October (Pelzeln). There remain the records of specimens taken in Chile (Sharpe) and at Colonia, Uruguay (Sharpe), without date of capture. Present knowledge is therefore summed up by the statement: It winters in South America, south to Chile and Uruguay. One specimen is recorded as taken at Laguna del Rosario, Mexico, in January (Ferrari-Perez), and one at Corpus Christi, Tex., January 19, 1890 (Sennett). As already stated, it is not probable that the stilt sandpiper winters regularly at either of these localities. One taken February 8, 1892, at Manzanillo, Mexico, by Nelson and Goldman of the Biological Survey, may have been an early spring migrant.

Spring migration.-The species is rare in spring migration along the Atlantic coast-indeed, the records are so few that it might be called occasional or even accidental: Some of these records are: Jamaica, April (March); Cuba, April (Gundlach); Sullivan Island, South Carolina, May 11, 1885 (Sennett); Cape Hatteras, North Carolina, May 19, 1898 (Pearson); Long Island, New York, once in May (Chapman), one June 16, 1863 (specimen in United States National Museum); Rhode Island, May 9, 1895 (Howe and Sturtevant). The principal route of spring migration seems to be up the Mississippi Valley and particularly along the direct course from the coast of Texas to Great Slave Lake. Most of the dates of arrival are in May. Some of the more northern are: Indian Head, Saskatchewan, May 18, 1892 (Macoun); Fort Resolution, Mackenzie, May 19, 1860 (Kennicott); Cheyenne, Wyo., May 25; 1889 (Bond); Fort Chipewyan Alberta, 
June 6, 1893 (Russell); the last one noted at Indian Head in 1892 was June 5 (Macoun). Eggs were taken on Anderson River, Mackenzie, June 24, 1863; at Rendezvous Lake, June 27, 1865; and young at Franklin Bay, July 8, 1865 (MacFarlane).

Fall migration. - That fall migration begins as early as possible is evidenced by the presence of the species in Peru and Brazil by August. It is said to arrive on Grenada and Barbados, West Indies, in July, and the earliest records on the Atlantic coast of each of the New England States is in the same month-earliest July 6, 1874, near Newport, R. I. (Sturtevant). As late as 1879 Doctor Brewer stated that it was not yet known to be a regular migrant in this region, while a gunner near Newport, R. I., had listed 279 individuals, shot in 1867-1874, the dates ranging from July 6 to September 19 (Sturtevant), but these records were not published until 1901. Along this part of its course the species is most common in August, and most have departed by early September. Some late dates are: Newfoundland, one September, 1867 (Reeks); St. John, New Brunswick, September 8, 1881 (Chamberlain); Portland, Me., October 13, 1906 (Eastman); Key West, Fla., November 1, 1888 (Scott); Barbados (Feilden), Grenada (Wells), and in Trinidad (Leotaud), a few remain until October. The species has been noted as casual or accidental in Colorado (Thorne), Montana (Coues), British Columbia (Brooks), and Bermuda (Hurdis).

\section{Knot. Tringa canutus Linn.}

Breeding range.-The summer range of the knot is almost circumpolar, extending from Iceland across the whole of Arctic America and westward to northwestern Siberia. The species has also been taken once in Spitzbergen, but seems in general to be lacking in the Arctic regions north of Europe. There is every reason for believing that the species breeds locally throughout its summer range, but authentic eggs are a great desideratum. Eggs claimed to be positively identified have been collected at four localities: Fort Conger, Grinnell Land, June 9, 1883 (Greely); Disko, Greenland, 1875 (Seebohm); Iceland, June 17, 1898 (Ottosson); Taimyr Peninsula, Siberia, July 6, 1901 (Dresser). These eggs differ so much in size, shape, and coloration that some of them must have been wrongly identified. One of the latesit expeditions into the Arctic regions saw young at Goose Fiord, latitude $76^{\circ} 30^{\prime} \mathrm{N}$., but found no eggs (Sverdrup). The species was found breeding commonly at Igloolik on Melville Peninsula, latitude $69^{\circ}$, in the summer of 1823 (Parry), but none of the many eggs collected were preserved. Three years earlier it had been noted as an abundant breeder on Melville Island (Sabine). At that time the bird was undoubtedly many times more common than now. The Iceland record at $66^{\circ}$ latitude is the most southern breeding record, and nestlings have been taken on Grinnell Land at $82^{\circ} 44^{\prime}$ latitude, These represent the extremes of the breeding range. 
Winter range.-The breeding knots of Siberia go south in winter to southern Africa, India, Australia, and New Zealand; those from Arctic America winter in South America, south to Tierra del Fuego, where they were found to be common February, 1895 (Schalow). The species is recorded locally from the coasts of South America, but present data are not sufficient to define the northern limits of the winter range. It is not probable that the knot winters regularly anywhere north of South America, and all records to the contrary, as the three seen in January, 1890, on Muskeget, Mass. (Mackay), must be considered as accidental. On Barbados the species has been noted as late as December 27, 1886 (Manning), but it is there considered to be only a migrant.

Migration range.-The principal migration route is along the Atlantic coast, where the knot is known locally from Florida to Newfoundland, and was formerly quite common. There are notable gaps in the records of this species. It is known locally as a tolerably common migrant throughout the Mississippi Valley east of the ninetyeighth meridian, but apparently these Mississippi Valley birds pass north and a little east to Hudson Bay and thence to the Arctic islands, for the species is unrecorded in the whole interior of Canada west of Hudson Bay, and has not been found even on the Arctic coast of Mackenzie. Southward there is another break in the records, for the specimen taken April 13, 1904, at Rivera, Veracruz (Piper), seems to be the first and only record for Mexico, and there is none for Central America, though the species is moderately common in Texas south to Corpus Christi (Sennett). A few individuals of this species have been seen in migration on the Pacific coast from San Diego, Calif. (Dwight), to Cape Blossom, Alaska (Grinnell).

Spring migration.-The knot arrives on the United States coast in April, but the larger flocks come about the middle of May, and there is no apparent difference in the dates for the whole coast from Florida to Massachusetts. An early date is March 28, at Grand Isle, Louisiana (Beyer, Allison, and Kopman). Near the northern limit of the range some dates of arrival are: Point Barrow, latitude $71^{\circ} 20^{\prime} \mathrm{N}$., May 30, 1883 (Murdoch); Fort Conger, latitude $81^{\circ} 40^{\prime}$ N., June 3, 1883 (Greely); Floeberg Beach, latitude $82^{\circ} 30^{\prime}$ N., June 5, 1876 (Feilden), while far to the southward at Winter Island, latitude $66^{\circ}$ N., the first was not noted until June 16, 1822 (Parry), and the next year at Igloolik, a few miles farther north, not until June 14 (Parry).

Fall migration.-Birds from the north arrive on the coast of Massachusetts, on Long Island, and in some seasons, even on the coast of South Carolina (Wayne), by the middle of July; the first was seen at the Olympiades, Wash., July 7, 1905 (Dawson). It seems scarcely possible that these early arrivals can have bred the same year, for earliest dates of young are in July and that at places 2,000 miles or 
more to the northward. August is the month of principal migration from Maine to South America, and this month also witnesses the departure from the breeding grounds. The last one seen at Floeberg Beach was August 29, 1875 (Feilden); Point Barrow, August 17, 1898 (Stone); Homer, Alaska, August 23, 1901; Winter Island, Melville Peninsula, August 17, 1822 (Greely). During the summer of 1822 the entire stay of the knot on Winter Island was only sixtytwo days--one of the shortest nesting periods of any species.

\section{Purple Sandpiper. Arquatella maritima (Brinn.).}

Breeding range.-The purple sandpiper is principally a bird of the old World, breeding on the Arctic coast and islands from northwestern Siberia to Iceland. In Greenland it is known on the east coast to Shannon Island, latitude $75^{\circ}$ N. (Schalow); and on the west to Thank God Harbor, $81^{\circ} 40^{\prime} \mathrm{N}$. (Bessels); and probably it breeds at least as far north as latitude $72^{\circ}$. A few were seen at Fort Conger, on Grinnell Land (Greely); several at various times in the fall around Wellington Channel (McCormick); and the species was found common in summer on Banks (Armstrong) and Melville (Ross) islands. The Banks Island record at latitude $74^{\circ} \mathrm{N}$., longitude $118^{\circ} \mathrm{W}$., marks the extreme northwestern range of the species. To the westward of this it is replaced by couesi. The southern limit of the breeding range appears to extend from the southern end of Greenland to the base of the Melville Peninsula, and possibly to the northern shores of Hudson Bay. The species breeds most commonly on the shores of Baffin Bay and Davis Strait.

Winter range.-The purple sandpiper remains the farthest north in winter of any of the shorebirds. It is said to winter sometimes even in southern Greenland (Hagerup), and it is common in winter from Nova Scotia (Sharpe) and New Brunswick(Macoun) southward to the coast of Rhode Island (Howe and Sturtevant). It is a rare but regular winter visitant to Long Island, New York (Dutcher), and has occurred casually thence south to the Bermudas (Reid), Georgia (Sennett), and Florida (Scott). The species is rare anywhere away from the ocean, but has been noted a few times in the vicinity of the Great Lakes.

Spring migration.-Some dates of spring arrival are: Winter Island, June 10, 1822 (Greely); Igloolik, June 14, 1823 (Greely); Cambridge Bay, June 10, 1853 (Greely); Bay of Mercy, June 3, 1852 (Armstrong); Cumberland Sound, June 4, 1878 (Kumlien); Prince of Wales Sound, Ungava, May 27, 1886 (Payne); west coast of Greenland at latitude $72^{\circ}$ N., May 29, 1850 (Sutherland). The last usually desert the New England coast in March.

Fall migration.-Occasionally a stray bird appears in September on the New England coast, but the main flocks do not arrive until 52928는 $35-10-3$ 
November or December. The species is not late in deserting the far North, as evidenced by the following dates of the last ones seen: Thank God Harbor, Greenland, September 11, 1871 (Bessels); Possession Bay, Franklin, September 1, 1818 (Sabine); Wellington Channel, August 28, 1852 (McCormick). At Cumberland Sound a few remained in 1877 until November (Kumlien).

Aleutian Sandpiper. Arquatella maritima couesi Ridgw.

The western coast of Alaska and the Aleutian Islands seem to be the principal home of the Aleutian sandpiper. It breeds throughout the whole of the Aleutian Chain, east to the Shumagin Islands (Dall); and also to the westward on the Commander Islands of Asia (Stejneger). It winters on the Aleutians and south along the mainland of Alaska to Sitka (Bischoff). A few of the breeding birds of the Commander Islands remain throughout the winter, but most of them go south as far as the Kurile Islands (Sharpe).

Early in August, when the young are strong of wing, great flocks move north and appear on the west coast of the mainland of Alaska, at least as far north as Kotzebue Sound (Nelson); they occur also inland to Nulato (Dall), and on the Asiatic side at least to Plover Bay (Dall). This northward migration takes them also to the Pribilof Islands (Seale). They remain in this northern part of the range until driven south by the gathering ice; the last leave Norton Sound about the middle of October (Nelson). The earliest records of eggs taken on Bering Island are about the middle of May (Stejneger), and on Unalaska Island the first week in June (Reed).

Pribilof Sandpiper. Arquatella maritima ptilocnemis (Coues).

The name Pribilof sandpiper indicates the principal breeding place, but in addition, the species has been found breeding on the islands of St. Lawrence (Nelson), St. Matthew (Elliott), and Hall (Grinnell). It has been taken from July 17 to August 29 on the shores of Norton Sound (McGregor), but there is nothing to indicate that it breeds in the vicinity, and its occurrence there is probably due to a northward migration after the breeding season. The main winter home has not yet been ascertained, and the only winter records to date are those of a few seen in December and January at Portage Bay, near the base of the Alaska Peninsula (Hartlaub). In spring migration the Pribilof sandpiper has been taken April 1-14 at Nushagak, Alaska (Palmer), and in fall migration August 5-14 near Unalaska Island (McGregor). Eggs have been found on the Pribilof Islands from June 19 to July 6 (Prentiss).

Sharp-tailed Sandpiper. Pisobia aurita (Latham).

The breeding range of the sharp-tailed sandpiper is not well known. The bird occurs in summer on the north shore of Siberia at Cape Waukarem (Nelson) and the Chuckchi Peninsula (Palmen), and this 
is probably the principal breeding range. The species winters in Australia and New Zealand and migrates through the Commander Islands, Japan, China, and the Malay Archipelago.

All the records for North America seem to be during the fall migration, at which period-crossing to America on the way to its winter home in Asia - it is fairly common in Alaska on the shores of Norton Sound, and has been noted north to Port Clarence and Hotham Inlet (Nelson). It has been taken a few times on the Pribilof Islands, once on Unalaska Island (Bishop), once on Queen Charlotte Islands (Fannin), and once on Vancouver Island (Brooks). The period of occurrence on the coast of America extends from August 17, when the first was seen on the Pribilof Islands (Grinnell), to October 12, the date of the last seen in Norton Sound (Nelson). The two individuals taken December 27, 1897, on Queen Charlotte Islands (Fannin), were probably stragglers.

\section{Pectoral Sandpiper. Pisobid maculata (Vieill.).}

Breeding range.-The principal known summer home of the pectoral sandpiper is the coast of northwestern Alaska, from the mouth of the Yukon (Nelson) to Point Barrow (Murdoch). The principal authority on the birds of the Arctic coast east of the Mackenzie is MacFarlane, and he reports that the pectoral sandpiper was rare in the vicinity of Fort Anderson and Franklin Bay, and that he was never able to find the nest. This must have been a local peculiarity of distribution, for Edward A. Preble, of the Biological Survey, found the species abundant in August, 1900, on the barren grounds of the western shore of Hudson Bay; the species is also a common fall migrant on the coast of Ungava (Coues). Undoubtedly all these birds of Keewatin and Ungava nest along the neighboring Arctic coast, where, indeed, the eggs have been taken at Cambridge Bay, Franklin (Collinson).

Winter range.-In winter the species passes to southern South America, at least as far south as Port Desire, Argentina, latitude $40^{\circ} 30^{\prime} \mathrm{S}$. (Sharpe), and to Antofagasta, Chile, $23^{\circ} 30^{\prime} \mathrm{S}$. (Philippi). It winters in northern Argentina (Durnford) and as far north as Bolivia (Salvadori) and Peru (Sharpe). Though confined in summer to the seacoast, yet in its migrations it has been noted in Colorado at 13,000 feet (Morrison), and in its South American winter home it is not uncommon in the mountains to 12,000 feet (Sclater).

Migration range.-The pectoral sandpiper has a very pronounced southeastward migration in the fall. How far west the range extends in the Arctics is not yet known, but the bird has been found in late July and August along the northern coast of Siberia as far west as the Taimyr Peninsula (Palmen), and it may sometimes be found on this coast as a breeder. From these far western localities, it starts east and south along the Alaska coast, and a few visit the Pribilof Islands (specimen in United States National Museum) and the eastern 
Aleutians (Bishop), but the species is nowhere common on the Pacific coast south of Alaska, showing that most of the Alaskan and Siberian birds cross the Rocky Mountains and migrate southeastward to the winter home. A few pass south along the Pacific coast to the State of Washington (Suckley), and there are two records for California-Mill Valley Junction, September 14, 1896 (Mailliard), and Farallon Islands, September 4, 1884 (specimen in United States National Mueseum). The species reappears again in Lower California, where it is fairly common during fall migration in the Cape Region (Brewster).

The species is well known as a migrant on the west coast of Greenland as far north as Upernivik, latitude $73^{\circ}$ (Winge). It is a common migrant throughout the whole of North America east of the Rocky Mountains, and of the West Indies and Central America. It is strangely rare in the northern part of South America, where it seems to be unrecorded in Venezuela and Guiana, and to have been recorded only once from Colombia (Allen). It is common in migration in Ecuador and Brazil.

Spring migration.-The start from the South American winter home must be very early - February, or more likely January-for the average date of arrival at Raleigh, N. C., is March 23; earliest March 21, 1889 (Brimley). Raleigh is full 2,000 miles from the nearest boundary of the winter range, and probably these birds had already traveled over 3,000 miles when they appeared at Raleigh. Some other spring dates are: Beaver, Pa., average April 4, earliest April 1, 1890 (Todd); Erie, Pa., March 23, 1895 (Todd); New Orleans, La., March 7, 1896 (Allison); Hidalgo, Tex., March 16, 1890 (Sennett); St. Louis, Mo., March 17, 1884 (Widmann); Chicago, Ill., average of seven years, March 31, earliest March 27, 1897 (Blackwelder); Terre Haute, Ind., average March 26, earliest March 17, 1887 (Evermann); Ottawa, Ontario, average April 30, earliest April 27, 1894 (White); Keokuk, Iowa, average April 1, earliest March 17, 1893 (Currier); Fort Resolution, Mackenzie, May 19, 1860 (Kennicott); Fort Providence, Mackenzie, May 14, 1905 (specimens in collection Biological Survey); Fort Simpson, Mackenzie, May 16, 1904 (Preble); Dawson, Yukon, May 19, 1899 (Cantwell); St. Michael, Alaska, May 24, 1879 (Nelson); Kowak River, Alaska, May 27, 1899 (Grinnell); Point Barrow, Alaska, May 30, 1883 (Murdoch), and May 30, 1898 (Stone). Eggs were secured at Cape Lisburne, Alaska, June 5, 1885 (Woolfe), and at Point Barrow, June 20-July 10, 1883 (Murdoch).

Fall migration.-In common with many other shorebirds, the pectoral sandpiper begins, its fall migrations in July; indeed, it is probable that some start southward in June, for the average date of arrival on the coast of Mississippi is July 19, earliest July 15, 1903 (Allison); and at New Orleans, La., earliest July 17, 1895 (Blakemore). These birds were already more than 2,000 miles 
south of their breeding grounds, and had probably traveled all of this distance, for the pectoral sandpiper is not one of the species whose nonbreeders remain through the summer far south of the nesting grounds. If the fall migration was made at the same speed as the spring migration, about 35 miles per day, these July Gulf coast birds would have had to start on the return trip the middle of May, or earlier than they reach their breeding grounds. The records of this species combined with those of many others seem to indicate that the earliest fall migrants travel at a higher speed than the earliest spring migrants. This high speed in the case of the pectoral sandpiper is continued to South America and brings the first to Argentina by the end of August (Sclater and Hudson).

The regular fall migration of the young birds is a full month later, and they reach the coast of Ungava after the middle of August (Coues). Some late dates are: Northern coast of Siberia, August 20 (Pelzeln); Point Barrow, September 6, 1882 (Murdoch); St. Michael, September 6, 1899 (Osgood); Unalaska Island, October 5, 1899 (Bishop); Nushagak, Alaska, October 15, 1884 (Osgood); southern British Columbia, average October 16, latest October 25, 1905 (Brooks); Terry, Mont., October 21, 1905 (Cameron); Great Bear Lake, August 29, 1903 (Preble); Montreal, average October 25, latest November 1, 1890 (Wintle); Ottawa, Ontario, average October 29, latest November 5, 1895 (White); Lincoln, Nebr., November 4, 1899 (Wolcott); Keokuk, Iowa, November 24, 1900 (Currier); Carlisle, Pa., November 2, 1844 (Baird); Raleigh, N. C., November 15, 1894 (Brimley). A gunner near Newport, R. I., who shot 2,337 birds in 1867-1874, killed most of them between August 10 and October 10extreme dates July 16, 1870, and October 20, 1874 (Sturtevant).

\section{White-rumped Sandpiper. Pisobia fuscicollis (Vieill.).}

Breeding range.-The only nests and eggs of the white-rumped sandpiper so far reported are those taken near the coast of Franklin Bay, Mackenzie, and on the neighboring Barren Grounds (MacFarlane). The species was seen near Cumberland Sound July, 1878 (Kumlien), under such conditions as to make it probable that it was breeding, and is recorded as breeding at Cape Fullerton, Hudson Bay (Low). Many specimens have been taken on the west coast of Greenland from near the southern end north to Upernivik, latitude $73^{\circ}$ (Winge), but there is no proof that any of these were breeding. At Point Barrow, Alaska, the species was noted June 6-July 6, 1883 (Murdoch), and June 2-14, 1898 (Stone), but again there is no certainty of breeding. None of the expeditions that lived and collected on Boothia Peninsula and Melville Peninsula mention this species, and it is not known to breed south of Hudson Strait. It is evident, therefore, that the thousands of individuals of this species are crowded during the breeding season into a rather narrow belt of tundra 
extending from near the mouth of the Mackenzie east to the southern end of Baffin Land.

Winter range.-Few species of shorebirds have so many records for Patagonia as the white-rumped, and this is also one of the species that is erroneously said to breed in the Southern Hemisphere. It winters abundantly from Paraguay and Argentina to the Falkland Islands (Sclater and Salvin) and the southern coast of Tierra del Fuego (Schalow). It is rare or casual on the coast of Chile (Gay) and unknown on the rest of the western coast of South America, except one seen at Chorillos, Peru (Taczanowski), and one taken October 12, 1864, near Huanaracama, Peru (specimen in United States National Museum).

Migration range.-During migration the white-rumped sandpiper is common along the whole eastern coast of South America, in the West Indies, and in the United States east of the Rocky Mountains. The western edge of the migration route extends from the upper Mackenzie through western Saskatchewan and eastern Colorado to the coast of southern Texas and then turns east to northern Yucatan and the island of Trinidad. The species is only an accidental visitant to Mexico (Salvin), Central America, and the whole of northwestern South America. Accidental once in California (Bryant) and several times in Europe.

Spring migration.-The species arrives in Cuba in April (Gundlach) and has been recorded in northern Yucatan April 15 (Salvin). Nearly all the dates of arrival in the United States are in May, from Florida to Maine and from Massachusetts to Colorado. The first was seen at Indian Head, Saskatchewan, May 9, 1892 (Macoun); Fort Chipewyan, Alberta, May 30, 1893 (Russell); Fort Resolution, Mackenzie, May 19, 1860 (Kennicott); Cape Fullerton, Hudson Bay, May 22, 1904 (Eifrig). There are indications that the larger number pass north in spring by way of the Mississippi Valley and return in fall along the. Atlantic coast; but some individuals are found on the Atlantic coast in spring, though rare north of Virginia, and a few occur in the eastern Mississippi Valley in fall. The most surprising feature of this bird's migration is its late stay in spring south of its breeding grounds. Near Cape Horn, South America, it was abundant the winter of 1882-83 and remained until March 7, 1883 (Oustalet). It remains in southeastern Argentina until late April (Holland), and a single specimen was taken at Colonia, Uruguay, in June (Sharpe). The species remains regularly in Brazil until May (Pelzeln); one was taken on Inagua. Bahamas, May 27, 1879 (Cory); Amelia Island, Florida, May 30, 1906 (Worthington); Erie, Pa., June 4, 1875 (Sennett); Stafford County, Kans., June 6, 1907 (Peabody); Waukegan, Ill., June 9, 1876 (Nelson); Toronto, Ontario, June 21, 1898 (Nash); and at Indian Head, Saskatchewan, the last did not leave for the north until July 1, 1892 (Mrcoun). 
Fall migration.-By early July the species is already moving south and arrived soon after July 1,1886 , at Prince of Wales Sound, Ungava (Payne), just south of the breeding grounds. During the month of July the van appears all along the New England coast, and even reaches Barbados (Feilden). August finds the species in Brazil (Pelżeln), and the collectors near Cape Horn in 1882 recorded the arrival of the first September 9 (Oustalet).

The main part reaches the northern United States in August, usually about the second week; the last leave the breeding grounds soon after the 1st of September, and the birds are seldom seen on the New England coast after the middle of October. One was taken at Ossining, N. Y., October 21, 1879 (Fisher), and a late migrant was taken at Lake Drummond, Virginia, November 5, 1898 (Fisher).

Baird Sandpiper. Pisobia bairdi (Coues).

Breeding range.-The Baird sandpiper has been found breeding at Point Barrow, Alaska (Murdoch), in the vicinity of Franklin Bay, Mackenzie (MacFarlane), and at Cambridge Bay, Franklin (Collinson). These localities probably represent the real extremes of the breeding range, for east or west of these limits the species is known very rarely even in migration.

Winter range.--During migration the Baird sandpiper has been noted near the summit of one of the highest mountains of Colorado at 14,000 feet (Drew). The same tendency to seek a high altitude is shown in the winter home, for this species has been taken repeatedly in the high mountains of northern Chile at 10,000 to 12,000 feet, and one specimen was secured at over 13,000 feet altitude (Sclater). Chile seems to be the principal winter home of the species, and it has been recorded here south to Talcahuano, latitude $36^{\circ} 30^{\prime} \mathrm{S}$. (Sharpe). It is said to have occurred in Patagonia (Carbajal), but no definite locality is given, and in Argentina it seems not to have been recorded south of Buenos Aires (Sclater and Hudson).

Migration range.-The route the Baird sandpiper traverses between its winter and summer homes is yet to be determined. In spring migration the species is practically unknown east of the Mississippi River, and is abundant on the coast of Texas, on the plains, and in the Rocky Mountain region. Though many individuals occur in the eastern Ưnited States in fall, yet the bulk retraces its spring course and leaves the United States to the southward of the plains region. It has been noted in a few places in Mexico in fall: Colonia Garcia, Chihuahua, September 4; Chihuahua City, October 3 (Nelson); San Jose del Cabo, September 3-13 (Brewster); Janos River, Chihuahua, September 5 (Wolfe); Las Vigas, Jalapa, September (Sharpe); and Zacatecas, August 16 (Sharpe); here the record ends. The species is not recorded for Guatemala, Honduras, or Nicaragua. It is a common fall migrant in Ecuador (Salvadori and Festa), but the only records 
between Mexico and Ecuador are: Volcano Irazu, Costa Rica, June 8 (Cherrie); La Estrelle de Cartago, Costa Rica, November 5, 1907 (Carriker); and Medellin, Colombia (Sclater and Salvin), without date of observation.

Not many years ago the Baird sandpiper was considered merely accidental on the Atlantic coast. The past few years have witnessed a great increase of data. It is now known to be a regular and not rare migrant east to Lake Huron (Wood), Lake Erie (Todd), and the western end of Lake Ontario (Nash), and there are 50 or more printed records for the Atlantic coast region, from Four Mile Run, Va. (Matthews), north to Digby, Nova Scotia (Macoun). What becomes of these Atlantic coast birds is not yet known, for the species seems to be unrecorded in the United States south of the Ohio River and east of Mississippi, and is not known in the West Indies. It ranges regularly west to British Columbia (Brooks), but to the southward the flocks seem to pass inland west of the Sierra and are common in Nevada (Ridgway) and Arizona (Henshaw), but rare in California, where it has been taken at Point Pinos (Mailliard) and September 8, 1904, at Pacific Beach (Bishop).

Spring migration.-The Baird sandpiper is a much earlier migrant than its eastern relative, the white-rumped. It appears on the coast of Texas in early March (Brown); the average date of arrival in central Nebraska is March 24, earliest March 19, 1890 (Powell); Loveland, Colo., March 29, 1890 (Smith); southern British Columbia, April 29, 1889, and 1905 (Brooks); Indian Head, Saskatchewan, May 9, 1892 (Macoun); Fort Resolution, Mackenzie, May 19, 1860 (Kennicott); near Dyer, Alaska, May 15, 1882 (Hartlaub); Kowak River, Alaska, May 20, 1899 (Grinnell); Point Barrow, Alaska, average of three years May 29, earliest May 28, 1898 (Stone). The date of arrival at Point Barrow is worthy of notice, for at this time the birds' breeding grounds on the tundra were covered deep with snow, and it had to wait some weeks before it could begin nesting. The earliest eggs at Fort Anderson were found June 24, 1864 (MacFarlane); the next year; young were noted July 5, and downy young were taken at Point Barrow July 16, 1898 (Stone).

The species remains in Chile until the last of March (Lane), and is common in Texas to the middle of May (Lloyd). A late migrant was taken June 1, 1903, at Iguala, Guerrero (Nelson and Goldman). The last usually leave Nebraska before the first of June, but in 1900 one was seen at Lincoln on June 29 (Wolcott). The last was noted at Indian Head, Saskatchewan, June 2, 1892 (Macoun), and at Fort Chipewyan, Alberta, June 1, 1893 (Russell).

Fall migration.-Several flocks already in fall migration were seen at Great Slave Lake, Mackenzie, July 10, 1901 (Preble). Since the earliest young are not hatched until the first week in July, it is evident 
that these flocks of July 10, already several hundred miles south of the breeding grounds, must consist either of barren birds or of those that had suffered loss of their eggs. In southern British Columbia, the average date of arrival is August 11, earliest August 6, 1888 (Brooks); near Monterey, Calif., August 25, 1897 (Mailliard); southern Saskatchewan, July 17, 1906 (Bishop); southern Manitoba, July 23, 1881 (Macoun); Lincoln, Nebr., August 9, 1900 (Wolcott); southern Ontario, July 28, 1891 (Nash); Locust Grove, N. Y., August 18, 1885 (Henshaw); Boston Harbor, August 27, 1870 (Henshaw); Montauk, N. Y., August 14, 1907 (Braislin). In September it reaches its winter home in southern South America.

The last were seen at Point Barrow, Alaska, August 12, 1883 (Murdoch), and September 4, 1897 (Stone); southern British Columbia, September 15, 1903 (Brooks); Fort Lyon, Colo., September 28, 1885 (Thorne); Lincoln, Nebr., November 3, 1900 (Wolcott); southern Ontario, October 20, 1893 (Elliott); New Haven, Conn:, October 28, 1887 (Woodruff) ; Galapagos Islands, October 6, 1897 (Rothschild and Hartert).

Least Sandpiper. Pisobia minutilla (Vieill.).

Breeding range.-The least sandpiper nests in the far north to northern Ungava (Turner); at Cambridge Bay in southern Franklin (Collinson); the coast of Mackenzie (MacFarlane); and Kotzebue Sound, Alaska (Grinnell). Unlike most of the Arctic breeding shorebirds, it breeds also quite far south to Sable Island (Oates); Magdalen Islands (Job); northeastern Quebec (Audubon); upper Hamilton River, Ungava (Low); Fort Churchill, Keewatin (Preble); Lake Marsh, southern Yukon (Bishop); and in Alaska south to Yakutat Bay (Merriam). The western limit of the breeding range in Alaska is not yet definitely settled.

Winter range.-The species is recorded without exact locality from Chile (Salvin), has been taken at several places in Peru (Taczanowski), and ranges south in Brazil to Pernambuco (Allen). Thence, it is known throughout northern South America, Central America, Mexico, and the West Indies, the coast of Georgia (Helme), rarely in winter to North Carolina (Bishop), southern Texas (Merrill), southern Arizona (specimen in United States National Museum), and southern California, north at least to Owen Lake (Fisher) and Humboldt Bay (Townsend).

Migration range.-Beyond the known breeding range, the least sandpiper is found in fall on the west coast of Greenland north to Godhaven, latitude $69^{\circ}$ (Walker); at Plover Bay, Siberia (Bean). It occurs during most if not all the summer on the Alaska Peninsula (Osgood) and on the Aleutian Islands west to Unalaska (specimen in United States National Museum).

Spring migration.-Though wintering so far north, this species is one of the later shorebirds to migrate. Most of the migrants cross 
the United States in early May, as shown by the following dates of arrival: Long Island, New York, average May 4, earliest April 21, 1906 (Latham); eastern Massachusetts, average May 8; city of Quebec, average May 2, earliest April 28, 1900 (Dionne); Chicago, Ill., average May 8, eariliest May 4, 1898 (Gault); Oberlin, Ohio, average May 12, earliest May 8, 1905 (Jones); southern Ontario, average May 15, earliest May 8, 1889 (McIlwraith); Ottawa, Ontario, average May 18, earliest May 10, 1888 (White); Onaga, Kans., average May 11, earliest May 9, 1904 (Crevecoeur); southern Saskatchewan, average May 17, earliest May 12, 1903 (Harvey); Fort Resolution, Maý 19, 1860 (Kennicott); Fort Providence, May 15, 1905 (Mills); Fort Simpson, May 17, 1904 (Preble); Loveland, Colo., average April 21, earliest April 19, 1890 (Smith); Cheyenne, Wyo., average April 28, earliest April 231888 (Bond); Newport, Oreg., average April 29, earliest April 21, 1901 (Bretherton); southern British Columbia, average April 22, earliest April 20, 1905 (Brooks); Nulato, Alaska, May 11, 1867 (Dall); Kowak River, Alaska, May 15, 1899 (Grinnell).

Eggs were taken near Fort Anderson, Mackenzie, June 21, 1862; June 24, 1863, and June 30, 1864 (MacFarlane); Yakutat Bay, Alaska, June 21, 1899 (Merriam); downy young at Lake Marsh, Yukon, July 2, 1899 (Bishop), and an egg ready to lay at the Kowak River, Alaska, June 1, 1899 (Grinnell).

Fall migration.-The following dates of arrival show how very early some individuals of the species must start southward: Sitka, Alaska, common July 2, 1896 (Grinnell); southern British Columbia, July 2, 1889 (Brooks); North Dalles, Wash., July 4, 1897 (Fisher); near San Diego, Calif., July 13, 1894 (Mearns); Fort Bridger, Wyo., July 13, 1858 (Drexler); Lincoln, Nebr., July 14, 1900 (Wolcott); Detroit, Mich., July 9, 1905 (Swales), July 7, 1906 (Taterner); near Toronto, Ontario, July 4, 1891 (Nash); Lexington, Ky:, July 16, 1905 (Dean); Long Island, Now York, average July 8, earliest July .6, 1898 (Worthington); Bahamas, July 16, 1903 (Riley), July 18, 1904 (Allen); the Lesser Antilles, the middle of July (Feilden); off. the coast of Venezuela, July 23, 1892 (Hartert).

Some dates of the last seen arè: Cape Blossom, Alaska, Auguist 10, 1898 (Grinnell); southern British Columbia, average September 11, latest September 18, 1903 (Brooks); Aweme, Manitoba, average September 4, latest September 26, 1899 (Criddle); Long Island, New York, September 17, 1905 (Latham); Erie, Pa., October 3, 1895 (Todd); Back River, Maryland, November 3, 1894 (Kirkwood).

Iong-toed stint. Pisobia damacensis (Horgf.).

The long-toed stint is a species of eastern Asia, aceidental in North America. It breeds in eastern Siberia, Kamchatka, Bering Island, and south to the Kurile Islands; west probably to the valley of the Lena River. This statement of breeding range is based on 
the occurrence of the species in summer, since the nest and eggs are still unknown. The species passes south for the winter, through China and Japan, to Australia, the Malay Archipelago, Burma, and India. The only record in North America is of a single specimen taken June 8, 1885, on Otter Island, Alaska (Ridgway).

\section{[Cooper Sandpiper. Pisobia cooperi (Baird).}

The Cooper sandpiper is known only from the single specimen now in the National Museum, taken in May, 1833, on Long Island. The status of the species is still in doubt.]

\section{Dunlin. Pelidna alpina (Linn.).}

The dunlin, an Old World species, has been noted a few times in North America. A specimen was taken October 20, 1842, at Washington, D. C., and two days later a second was secured (Smith); one was captured September 15, 1892, at Shinnecock Bay, Long Island, New York (Young), and one August 11, 1900, at Chatham, Mass. (Howe and Allen). There are less certain records of its occurrence in the region of Hudson Bay (Blakiston). There seems to be no sure record for Greenland, though the regular breeding range extends. west to England, Scotland, and Iceland. The species breeds east to Turkestan and probably to the valley of the Yenisei, and north to the islands of the Arctic coast. It winters from Great Britain and the Caspian Sea south to northern Africa and India.

\section{Red-backed Sandpiper. Pelidna alpina sakalina (Vieill.).}

Breeding range.-The red-backed sandpiper has two well-defined breeding areas corresponding in general to the Atlantic and Pacific winter ranges. The birds of the Atlantic coast breed from northeastern Ungava (Weiz) and Cape Fullerton, Hudson Bay (Low), north to Bellot Strait (McClintock). A few (of either this form or the last) breed on the west coast of Greenland, from which country there are eggs in the United States National Museum. The birds of the Pacific coast breed in Alaska from the mouth of. the Yukon (Nelson) north to Point Barrow (Murdoch), and on much of the northern coast of Siberia west possibly to Yenisei River (Seebohm). The region of intergradation along the coast of Siberia is not yet definitely determined. These two breeding areas are separated by nearly 1,500 miles of Arctic coast, from Point Barrow to the Boothia Peninsula, and throughout this whole region there seems to be no certain record of the occurrence of the red-backed sandpiper. If it does occur, it must be very rare, and the probability that it does not is increased by the fact that the species is not known as a migrant in the region immediately to the south. It is abundant as a migrant along the west coast of Hudson Bay (Preble) and has been taken at Dawson, Yukon (Cantwell), but as yet is unrecorded in the intervening districts.

Winter range.-Few of the shorebirds go so short a.distance to the southward as the red-backed sandpiper. It is common in winter 
as far south as central Florida (Scott), but is unknown in the Bahamas and the West Indies. On the coast of Texas it ranges to the mouth of the Rio Grande (Merrill), but is not yet known in northeastern Mexico. On the Pacific coast it is abundant south to southern Lower California (Belding), but seems not to pass farther south. The only record south of the region just outlined is that of a specimen, undoubtedly a straggler, taken May 23, at Momotomba, Nicaragua (specimen in British Museum). During the winter the species remains north to the coasts of North Carolina (Bishop), New Jersey, casually (Stone), Louisiana (Beyer), Texas (Carroll), and at least to central Washington (Bowles). The Siberian birds of this form winter from Japan and China to the Malay Archipelago.

Spring migration.-Most of the spring movements occur in May, but a few early birds press northward in April: Long Beach, New Jersey, April 17, 1877 (Scott); Long Island, New York, April 3, 1882 (Chapman); Erie, Pa., April 21, 1900 (Todd). On the Atlantic coast north of Massachusetts the species is not so common in spring as in fall, while around the Great Lakes the reverse is the case. The main body of the Atlantic coast birds seem to reach their breeding grounds by way of the Great Lakes and Hudson Bay. Along this route they are late migrants, reaching southern Ontario on the average May 20, earliest May 13, 1905 (Taverner).

The Pacific coast birds appeared in southern British Columbia April 25, 1888 (Brooks), and April 26, 1889 (Brooks); one was seen as early as April 2, 1897, at Howcan (Cantwell), in the extreme southern part of Alaska. Other dates of spring arrival are: Fort Kenai, May 16, 1869 (Osgood); Kigulik Mountains, May 17, 1905 (Anthony); Dawson, Yukon, May 24, 1899 (Cantwell); Point Barrow, Alaska, May 31, 1882 (Murdoch), May 29, 1883 (Mürdoch), and June 2, 1898 (Stone).

None were noted in Lower California after May 10 (Belding), but in central Florida they have been recorded as late as June 2, 1886 (Scott), and in southern Ontario the average date of the last seen is June 4, latest June 13, 1891 (Nash).

Eggs have been taken at the mouth of the Yukon, June 6, 1879 (Nelson); Cape Prince of Wales, June 27, 1898 (Grinnell); and at Point Barrow, June 22, 1883 (Murdoch). At this last locality the eggs in some seasons must be laid earlier than the above date, for in 1898 downy young were taken July 6 (Stone).

Fall migration.--Early fall migrants were passing south July 19, 1900, along the west shore of Hudson Bay, near York Factory (Preble), and two weeks later they were enormously abundant, showing that this is one of the principal routes in fall migration. Since the species is not common in the Mississippi Valley and is comparatively rare in western Ontario in the fall, it is evident that many of these Hudson 
Bay birds turn eastward to the Atlantic coast. An early arrival appeared on Long Island, New York, July 17, 1897 (Worthington), but the usual time of arrival is a month or more later; Hayward, Calif., August 3, 1889 (Emerson); Point de Monts, Quebec, August 28, 1883 (Merriam); Plymouth, Mass., September 17, 1852 (Browne); Erie, Pa., September 21, 1875 (Sennett); Washington, D. C., September 25, 1894 (Hasbrouck).

The last deserted the breeding grounds at Point Barrow, Alaska, September 7, 1882 (Murdoch); September 4,. 1897 (Stone). The last have been noted at St. George Island, Alaska, October 3, 1899 (Bishop); Bering Island, October 25, 1884 (Grebnitsky); Chicago, Ill., November 3, 1906 (Ferry); Oberlin, Ohio, October 27, 1906 (Jones); St. Clair Flats, Michigan, November 20, 1904 (Blain); Ottawa, Ontario, average October 4, latest October 29, 1889 (White); Portland, Me., November 11, 1906 (Eastman); Barnstable, Mass., December 23, 1903 (Howe); Comox, British Columbia, December 5, 1903 (Brooks).

\section{Curlew Sandpiper. Erolia ferruginea (Brünn.).}

The curlew sandpiper breeds only in the Eastern Hemisphere, but wanders not infrequently to the Atlantic coast of North America. The only eggs so far known were taken July 3, 1897, in the delta of the Yenisei River, Siberia (Newton), and June 24-July 6, 1900, on the northwestern coast of the Taimyr Peninsula, Siberia (Dresser). It is probable that all Greenland records for this species are erroneous, and that the only reliable record in Arctic America is that of the single individual taken June 8, 1883, at Point Barrow, Alaska (Murdoch). On the Atlantic coast of America it has been recorded about twenty times from Halifax, Nova Scotia (Jones), to Cape May, N. J. (Abbott). A few dates are in May, but the larger part are in the fall from August to October. One specimen was taken about 1886 in the interior at Toronto, Ont. (Fleming). The species has been recorded from Grenada Island, West Indies (Cory), and there is a specimen in the British Museum said to have been taken in eastern Patagonia.

In winter the curlew sandpiper ranges south to southern Africa, India, the Malay Archipelago, and Australia. During migration it has been noted in the Philippines and China, and west to Great Britain.

Spoon-bill Sandpiper. Eurynorhynchus pygmeus (Linn.).

The spoon-bill sandpiper inhabits the Eastern Hemisphere and ranges in summer to northeastern Siberia. It migrates through Japan and China and winters as far south as Burma and India. One was taken in 1849 on the Choris Peninsula of Alaska-the only record for the Western Hemisphere. 
Semipalmated Sandpiper. Ereunetes pusillus (Linn.).

Breeding range. -The semipalmated sandpiper breeds in Ungava at Okalk (Crandall) and south to Fort George (Drexler), and also on the Barren Grounds from Hudson Bay (Eifrig) west to Franklin Bay (MacFarlane), along the Arctic coast to Kotzebue Sound, Alaska (Grinnell), and south on the western coast of Alaska to St. Michael (specimens in United States National Museum).

Winter range.-It winters mainly in eastern South America, south to Patagonia (latitude $43^{\circ} \mathrm{S}$.) (Seebohm), and thence north through Central America and the West Indies to eastern Mexico (Sumichrast), southern Texas (Refugio County; Carroll), Florida (Scott), and the coast of Georgia (Helme) and South Carolina (specimen in United States National Museum).

Migration range.-The semipalmated sandpiper is a rare spring but an abundant fall migrant along the whole Atlantic coast. It is a common fall migrant through the Bermudas (Hurdis), Bahamas (Bryant), and the West Indies east of Cuba. It is common both spring and fall in the Mississippi Valley, becoming less common westward to the eastern base of the Rocky Mountains, and west of the mountains to western British Columbia (Brooks), Sitka, Alaska (Bischoff), Cook Inlet (Chapman), Norton Sound (McGregor), St. Paul Island (Palmer), and the coast of northeastern Siberia (Nelson). It has occurred in migration on the coast of Peru (Salvin).

Spring migration.-Almost all the spring records for the Atlantic coast are in May, while migration in the Mississippi Valley begins in April: Camden, Ind., average of three years April 21, earliest April 18, 1886 (Groninger); Keokuk, Iowa, average of eight years April 30, earliest April 19, 1898 (Currier); Fort Lyon, Colo., April 25, 1886 (Thorne); Indian Head, Saskatchewan, May 16, 1892 (Macoun); Fort Chipewyan, Alberta, May 24; 1901 (Preble); Great Bear Lake, Mackenzie, May 24, 1826 (Richardson); Kowak River, Alaska, May 29, 1899 (Grinnell). Nonbreeding birds are found here and there in summer from Wisconsin (Kumlien and Hollister) to Massachusetts (Howe and Allen).

Eggs have been taken at Fort George, Ungava, June 24, 1860 (Drexler); Franklin Bay, Mackenzie, June 30, 1864 (young July 5, 1865), (MacFarlane); St. Michael, Alaska, June 9, 1880 (specimens in United States National Museum); and young just hatched at Cape Blossom, Alaska, June 30, 1898 (Grinnell).

Fall migration.-Like so many other sandpipers the semipalmated begins to move south so early that it appears in the United States in July; southern Mississippi, average of three years July 16, earliest July 10, 1905 (Brodie and Kopman); Fernandina, Fla., July 14, 1906 (Worthington); Porto Rico, August 11, 1901 (Bowdish); La Guaira, Venezuela, August 10 (Robinson and Richmond), and Marajo, Brazil, 
August 4 (Allen). Specimens were taken July 3; 1907, at Coronado de Terraba, Costa Rica (Carriker), but these may have been nonbreeders that had not made the northward journey. Young birds migrate about a month later, and it is probably these that afford the following average dates: North River, Prince Edward Island, August 8 (Bain); Long Island, New York, August 10 (Worthington); Beaver Pa., August 14 (Todd); Keokulk, Iowa, August 18 (Currier).

The average date of the last one seen at Point Baprow, Alaska, is August 15, latest August 18, 1882 (Murdoch); Hersehel Island, Yukon, August 2, 1894 (Russell); York Factory, Keewatin, August 26, 1900 (Preble); Ottawa, average of the last one seen September 9, latest September 17, 1892 (White); Lewiston, Me., October 17, 1900 (Johnson); Ossining, N. Y., October 20, 1885 (Fisher); Washington, D. C., October 26, 1887 (Richmond).

Western Sandpiper. Ereunetes mauri Cabanis.

Breeding range.-The western sandpiper's breeding range, as at present known, is a narrow strip along the northwestern coast of Alaska from the mouth of the Yukon (specimens in United States National Museum) to Cape Prince of Wales (Grinnell).

Winter range.-Though breeding only on the northwest coast, this sandpiper is common in winter on the Atlantic coast from North Carolina (Bishop) to Florida (Scott). This long migration across the continent to the southeastward from the breeding grounds is very remarkable, and is not paralleled in the case of any other shorebird. It is, however, comparable with the migration of several species of ducks from the Mackenzie Valley to Chesapeake Bay. The species also winters from $\mathrm{La} \mathrm{Paz}$, Lower California (specimen in National Museum), to southern Mexico (Lawrence), Guatemala (Sharpe), Colombia (Ridgway), and Venezuela (Robinson), and undoubtedly to the Lesser Antilles, but its distribution in the West Indies is not yet known with any accuracy.

Migration range.-In passing from the summer to the winter home, the western sandpiper comes east to the Atlantic coast at least as far north as Massachusetts (Henshaw), and sometimes is quite common in the fall on Long Island (Braislin) and the coast of New Jersey (Baily). The strange fact is that there are no corresponding records from the interior to indicate the route by which these birds reach New England. The species seems not to be known north of southern Wisconsin (Kumlien and Hollister), Colorado (Osburn), and southern Wyoming (specimen in National Museum), while in all of the Mississippi Valley between the river and the Rocky Mountains the species is so very rare as to make it improbable that any large part of the New England birds migrate through this section. In fall migration the species is known west in the Aleutians to Unalaska Island (Palmer). 
Spring migration.-Along the Atlantic coast the species is almost unknown in spring north of its winter range; the few known occurrences are in May. To the westward some dates of spring arrival are: Galveston, Tex., March 24, 1891 (Singley); San Pedro River, Arizona, April 17, 1902 (Howard); Monterey, Calif., April 6, 1903 (Breninger); Redwood City, Calif., April 14, 1907 (Carriger and Pemberton); Corvallis, Oreg., April 21, 1899 (Woodcock); southern British Columbia, April 26, 1889, and April 20, 1905 (Brooks); Fort Kenai, Alaska, May 12, 1869 (Bischoff); St. Michael, May 28, 1874 (Turner).

Most of the individuals have left southern Lower California by May 10 (Belding) and the northern part by the middle of the month (Kaeding). The species was still present at Owen Lake, California, June 1, 1891 (Fisher). Eggs have been found at the mouth of the Yukon June 5 (specimens in United States National Museum) and near Cape Prince of Wales, June 28, 1898 (Grinnell).

Fall migration.-The first fall migrants were noted at Tulare Lake, California, July 7-8, 1907 (Goldman), and the species was taken off the coast of Venezuela July 7, 1895 (Robinson). The first of these records probably represents birds in migration; the other, nonbreeders that had summered far south of the breeding grounds. Some other fall records are: Southern British Columbia, average of five years August 14 as the date of fall arrival (Brooks); Semiahmoo Bay, Washington, July 15, 1857 (Kennerly); Santa Barbara, Calif., July 3, 1875 (Sharpe); Fort Bridger, Wyo., July 13, 1858, (Drexler); near Arco, Idaho, July 25, 1890 (Merriam); Rockport, Tex., August 12, 1905 (Howell); Monomoy. Island, Massachusetts, July 19, 1888 (Brewster); Charleston, S. C., about July 8 (Wayne); Haiti, July 11, 1883 (Stone); San Mateo, Tehuantepec, August 7, 1869 (specimen in United States National Museum). The latest date in southern British Columbia is September 11, 1889 (Brooks); Hayward, Calif., November 4, 1889 (Emerson); Monomoy Island, Massachusetts, September 19, 1888 (Brewster); Cape May County, N. J., September 15, 1895 (Baily); Washington; D. C., September 22, 1894 (Hasbrouck).

Sanderling. Calidris leucophæa (Pallas).

Breeding range.-The sanderling, is a cosmopolite, breeding and wintering in both hemispheres. It is known to breed north to Point Barrow, Alaska (Stone), Melville Island (Fisher), Grinnell Land (Feilden), both coasts of Greenland (Bessels and Winge), the Taimyr Peninsula, Siberia (Walter), and undoubtedly breeds on the New Siberian Islands (Newcombe). It breeds south to Iceland (Oates), to Cape Fullerton, Hudson Bay (Low), and to Franklin Bay, Mackenzie (MacFarlane).

Winter range.-Some sanderlings pass in winter to central Argentina (Tambo Point, $44^{\circ}$ S.: Durnford), and to Talcahuano, central Chile (Sharpe), 8,000 miles from the nearest breeding grounds; while 
others remain as common winter residents on the Atlantic coast of the southeastern United States north to North Carolina (Smithwick) and casually even tò Massachusetts (Mackay). The species winters on the coast of Texas (Merrill) and on the Pacific coast regularly to central California (Cooper) and occasionally to Washington (Cooper and Suckley).

It occurs in fall migration on the Hawaiian Islands, where it has been taken from September 25 to October 14 and where a few may winter (Henshaw).

The sanderlings of the eastern hemisphere winter from the Mediterranean and Japan south to southern Africa, the Malay Archipelago, and Oceania.

Migration range.-The sanderling is common on the coasts of the world and on the larger inland waters. It is abundant on both coasts of North America and common on the Great Lakes. It has been recorded in migration from almost every State of the Union, but is quite rare in all the district between the Great Lakes and the Pacific coast.

Spring migration.-The northward.movement begins in March, bringing the species the latter part of this month to the New England coast and to the central Mississippi Valley. Further advance is so slow that the sanderling is among the later birds to arrive at the breeding grounds, which are reached the first week in June. Some dates of spring arrival are: Fort Simpson, Mackenzie, May 29, 1904 (Preble); Point Barrow, Alaska, latitude $71^{\circ}$, June 2, 1882 (Murdoch), June 6, 1898 (Stone); Prince of Wales Strait, $73^{\circ}$, June 7, 1851 (Armstrong); Bay of Mercy, 74 ${ }^{\circ}$, June 3, 1852 (Armstrong);

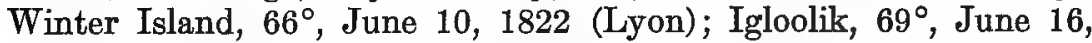
1.823 (Parry); Grinnell Land, $82^{\circ} 33^{\prime}$, June 4, 1876 (Fèilden); west coast of Greenland at $72^{\circ}$, May 29,1850 (Sutherland); at $78^{\circ}$, June 5, 1854 (Kane); Taimyr Peninsula, Siberia, 74 , June 4 (Seebohm). Specimens were taken in Chile in May (Schalow); in British Honduras May 18-20 (Salvin); southern Florida, May 25 (Scott); the coast of New Jersey, June 13 (Abbott). The species remains regularly on the New England coast and about the Great Lakes until the first week in June. The fact that nonbreeders remain through the summer far south of the nesting grounds has probably furnished the basis for the reports of the breeding of the species south of the Arctic coast.

The first eggs known to science were taken June 29, 1863, near Franklin Bay, Mackenzie (MacFarlane), a locality where the species is very rare. The most northern known eggs were taken June 24, 1876 , near the north coast of Grinnell Land, at latitude $82^{\circ} 33^{\prime}$ (Feilden). Eggs were taken in July at Thank God Harbor, Greenland (Bessels), and both late June and early July on the Taimyr Peninsula, Siberia (Walter).

52928 - Bull. $35-10-4$ 
Fall migration.-The sanderling was seen off the coast of Venezuela July 7, 1895 (Robinson), but regular fall migration does not begin until some weeks later, as shown by the following dates of fall arrival, which in each case are considerably earlier than the average: Big Stick Lake, Saskatchewan, July 19, 1906 (Bent); Lincoln, Nebr., August 7, 1900 (Wolcott); Toronto, Ontario, July 16, 1898 (Nash); Newfoundland, August 2, 1887 (Palmer); Erie, Pa., July 27, 1900 (Todd); Long Island, New York, July 20, 1900 (Scott); San Mateo, Téhuantepec, August 5, 1869 (Sumichrast). The last was seen at Point Barrow, August 27, 1897 (Stone); St. Michael, Alaska, September 11, 1899 (Bishop); Homer, Alaska, August 29, 1901 (Chapman); Prince of Wales Strait, August 30, 1850 (Armstrong); Grinnell Land, about August 31, 1882 (Greely); Prince Edward Island, October 30, 1887 (Bain); Montreal, Canada, October 7, 1889 (Wintle); Lincoln, Nebr., October 4, 1898 (Bruner, Wolcott, and Swenk); Ottawa, Ontario, October 22, 1887 (White); Erie, Pa., November 17, 1902 (Todd).

\section{Maxbled Godwit. Limosa fedoa (Linn.).}

Breeding range.-Formerly the marbled godwit was a common breeder in northern Nebraska (Say), in northern Iowa south to about latitude $43^{\circ}$ (Preston), and a few undoubtedly nested in Wisconsin, at about the same latitude (Kumlien and Hollister). It is not probable that the species now breeds in either State, and the principal summer home at the present time is from northern North Dakota (Rolfe) to the valley of the Saskatchewan (Bent).

Winter range.-The species passes south in winter to southern Guatemala (Salvin) and Belize (Sclater and Salvin), and remains as far north as southern Lower California (Forrer) and the coasts of Louisiana (Beyer), Florida (Scott), and Georgia (Worthington).

Migration range.-On the way from the summer home to the winter, some individuals formerly took a course almost due east and appeared in the Maritime Provinces of Canada (Macoun) and on the coast of New England (Brown), becoming more common to the south until it would hardly have been called rare on Long Island and the New Jersey coast. At the present time it is almost unknown on the Atlantie coast north of Florida. There seem to be no winter records of the species in the West Indies, but as a rare visitant in fall migration it has been recorded from Cuba (Gundlach), Porto Rico (Gundlach), Grenada (Wells), Carriacou (Wells), and Trinidad islands (Leotaud).

A migration also takes place westward to the Pacific coast. Though the species is not known to breed within several hundred miles of the Rocky Mountains, yet it has been noted on the coast of southern AJaska (Osgood) nearly a thousand miles west of the nearest breeding grounds. This species therefore presents the unique spectacle of a bird breeding in the middle of the American continent and migrating 
directly east and directly west to the ocean coasts. A wanderer was taken at Point Barrow, Alaska, August 26, 1897 (Stone), and several specimens have been taken on Hudson Bay (Preble). Individuals probably sometimes winter in California, as one was taken at Humboldt Bay, December 7, 1885 (Townsend), and at Lake Elsinore, February, 1902 (Nordhoff).

Spring migration.-The marbled godwit is among the earlier migrants of the shorebirds; it reaches central Illinois in early April (Griffin); Heron Lake, Minnesota, average April 12, earliest April 8, 1889 (Miller); Lincoln, Nebr., April 18, 1899 (Wolcott); Loveland, Colo., average April 27, earliest April 20, 1887 (Smith); Shoalwater Bay, Washington, April 13, 1854 (Cooper); southern Manitoba, average May 1, earliest April 29, 1901 (Wemyss); southern Saskatchewan, average May 3, earliest April 16, 1907 (Lang). Nearly all of the few spring records on the Atlantic coast are in May.

Eggs have been found at Oakland Valley, Iowa, April 20, 1878 (Rice); Winnebago, Iowa, May 6, 1871 (Krider); Miner County, S. Dak., May 16, 1892 (Patton); Minnewaukan, N. Dak., May 22, 1892 (Rolfe); in Grant County, Minn., May 24, 1876 (Sennett); and in southern Saskatchewan, May 29, 1905 (Bent). The birds and their young were common June 8, 1820, near the mouth of the Loup Fork of the Platte, Nebraska (Say).

Fall migration.-The return movement begins in July, since migrants have been taken at Ugashik, Alaska, July 16, 1881 (Osgood), on the New Jersey coast late in the month (Stone), and on Pea and Bodie islands, North Carolina, July 11, 1904 (Bishop). A gunner who shot for the market near Newport, R. I., obtained only 26 of these godwits during eight seasons, the extreme dates ranging from August 6, 1873, to October 2, 1868 (Sturtevant). The latest date in Colorado is October 1, 1874 (Henshaw).

\section{Pacific Godwit. Limosa lapponica baueri Naum.}

The principal breeding range of the Pacific godwit is in northeastern Siberia, but a few individuals cross to Alaska and breed from Unalaska (Dall) to Kotzebue Sound (Grinnell). After the breeding season some wander northward to Point Barrow (Murdoch). They arrive on their breeding grounds early in May (Nelson), and are among the earliest of the waders to begin the fall migration (Nelson). The latest one seen at Point Barrow was August 18 (Murdoch), and early in September the last have left North America. The migration route passes through the Pribilof Islands, Commander Islands, Japan, China, and the Philippines. The winter home is in Australia, New Zealand, the Malay Archipelago, and many of the islands of Oceania. The Pacific godwit has been noted several times in the Hawaiian Islands (Bryan), and a straggler was once taken at La Paz, Lower California (Belding). 
Hudsonian Godwit. Limosa hæmastica (Linn.).

Breeding range.-The eggs of the Hudsonian godwit are known only from the Anderson River region of northwestern Mackenzie (MacFarlane), but since Edward A. Preble, of the Biological Survey, found the species common in July and August on the west coast oi Hudson Bay, probably it breeds also not far north of this region. The breeding range is probably the Barren Grounds from the mouth of the Mackenzie to Hudson Bay.

Winter range.-The species winters in Argentina and Chile south to Chiloe Island (Sclater and Salvin) on the west coast and to the Strait of Magellan (Sharpe) and the Falkland Islands (Abbott). But it is rare in eastern Patagonia south of the Chubut River (Durnford), which is just opposite the southern limit on the western coast.

Migration range.-The migration route between the winter and summer homes is not known. In fall migration the species appears rarely on the coast of Maine (Boardman) and more commonly in Massachusetts (Howe and Allen), Rhode Island (Sturtevant), and Iong Island (Dutcher). Whither the birds go when they leave Long Island is as yet unknown. On the rest of the coast of the United States the species is known only as a very rare straggler. One accidental occurrence in Cuba (Gundlach) is the only record for the Greater Antilles, and in the Lesser Antilles it is known only from the extreme eastern end on Barbados (Feilden) and Trinidad (Leotaud). It occurs on the coast of British Guiana (Quelch) and in the interior of Brazil (Pelzeln).

The species seems not to be recorded in spring anywhere on the Atlantic coast between Argentina and Long Island, with the exception of a single pair seen May 8, 1906, near Rehoboth, Del. (Pennock). The very few records on Long Island (Sharpe) and in New England (Howe and Allen) during the spring indicate that at this season it is only a straggler along the Atlantic. It passes in spring migration up the Mississippi Valley, entering the United States through Louisiana (Beyer) and Texas (Sharpe) and passing north principally along the eastern edge of the plains. The migration route between Argentina and Texas is unknown, for there is not a single spring record in the whole distance, and records at any time in the year are limited to one on the coast of Peru, November 9, 1883 (MacFarlane); one in Cuba, no date specified (Gundlach); and very doubtful records for Colombia (Burger) and Costa Rica (Zeledon).

From the above very meager data, it seems probable that the Hudsonian godwit has a migration route similar to that of the golden plover, with this important difference-that whereas the golden plover first goes eastward from its breeding grounds to the coast of Labrador and crossing the Gulf of St. Lawrence strikes out to sea from Nova Scotia, the Hudsonian godwit starts in a south- 
easterly course to and down the western shore of Hudson Bay and keeps much this same course overland to the coast of New England. Thence it goes directly across the ocean to the Lesser Antilles and British Guiana, and lastly south and southwest through central Brazil to the pampas of Argentina, and to the coast of central Chile. Judging by analogy from the golden plover, the spring migration route of the Hudsonian godwit is from the pampas of northwestern Argentina directly to the coast of Texas, and almost in one flight.

This species is rare west of the Rocky Mountains. The British Museum contains specimens said to have been taken in California (Sharpe), but as this is the only record for the State it needs confirmation. A few specimens have been taken in Alaska from the Kenai Peninsula (Osgood) to the Yukon mouth (Dall and Bannister), Nulato (Sharpe), and Point Barrow (Stone) on the north, but there is no evidence that the species breeds west of the Mackenzie River. Though the Hudsonian godwit is now very rare on the New England coast, and has been since about 1886 , yet previously it was so common that a gunner near Newport, R. I., records the shooting of 104 birds in the years 1867-1874 (Sturtevant).

Spring migration.-The species arrives on the coast of Texas in April (Sharpe) and has been recorded at Lawrence, Kans., as early as April 19, 1873 (Snow); St. Louis, Mo., April 19, 1872 (Hurter); in Grant County, Minn., April 25, 1876 (Sennett); Indian Head, Saskatchewan, May 11, 1892 (Macoun); Fort Kenai, Alaska, May 5, 1869 (Bischoff). Specimens were taken on the Falkland Islands as late as May 20, 1860 (Abbott), and in Argentina to May 24 (Sharpe). The earliest eggs taken were on June 7, 1862, at Fort Anderson (MacFarlane).

Fall migration.-A Biological Survey party found the Hudsonian godwit already in southward migration July 19, 1900, near York Factory, Keewatin (Preble); it was noted July 29, 1869, on the coast of Rhode Island (Sturtevant); it arrives in August in the Lesser Antilles (Leotaud); in September in Brazil (Pelzeln); and by early November has appeared at the extreme southern limit of the range (Durnford). It is probably the arrival of young birds that is recorded at Barbados (Feilden) in October, with October 7 as the average of three years and October 5, 1886, as the earliest.

The last seen near Cape Churchill, Hudson Bay, in 1900, was on August 24 (Preble); Toronto, Ontario, October 20, 1890 (Fleming); Montreal, Canada, October 11, 1895 (Wintle); Rhode Island, October 13, 1873 (Sturtevant), and Massachusetts, November 3 (Howe and Allen).

Black-tailed Godwit. Limosa limosa (Linn.).

The black-tailed godwit is confined to the Eastern Hemisphere, breeding in Iceland, and from Holland and southern Russia north to the Anctic Circle and east to western Siberia. It winters in southern 
Europe and south to Abyssinia. A specimen was taken about 1830 near Godthaab, Greenland (Reinhard), and there are other less certain records of its occurrence in that country.

\section{Green-shank. Glottis nebularia (Gunn.).}

The green-shank has a very wide range in the Eastern Hemisphere. It breeds in Scotland, northern Scandinavia, and east to northern Siberia; it migrates along the coasts of both Europe and Asia, even to Japan and the Commander Islands; it winters from southern Europe and India to southern Africa and Australia.

The only record for the United States is that of three specimens taken by Audubon, May 28, 1832, on Sand Key, near Cape Sable, Florida. The species has also been recorded as an accidental visitant to Chile (Schlegel) and Buenos Aires, Argentina (Seebohm).

Common Red-shank. Totanus totanus (Linn.).

The common red-shank is scarcely entitled to a place among North American birds. Its claim resta only on the description by Swainson and Richardson of a specimen from Hudson Bay which they said existed in the British Museum.

The common red-shank is a well-known species of Europe and Asia, where it breeds from Iceland and the Faroe Islands to southern Siberia and Turkestan and south to northern Africa. It winters in southern Europe, throughout most of Africa, and in

- Asia south to India and the Malay Archipelago.

\section{Greater Yellow-legs. Totanus melanoleucus (Gmel.).}

Breeding range.-Knowledge of the summer home of the greater yellow-legs is much lacking in definiteness. One of the best known facts is that the bird does not go far north, since it is one of the few species of the family not found on the Arctic coast, nor even to the Arctic Circle. The most northern records are: Near Fort Chimo, Ungava (Turner); accidental once at Cumberland Sound (Kumlien); on the west shore of Hudson Bay to about Cape Eskimo (Preble); Fort Simpson, Mackenzie (Ross); and to Kupreanof Island (Osgood), Lake Iliamna (Osgood), and St. Paul Island (Seale)-all in Alaska. The southern limit of the breeding range is more difficult to determine, since the mere presence of the bird in summer is not sufficient proof that it is breeding. Individuals are found during every month of the year in the West Indies, Bahamas, Florida, Texas (Sennett), and California (Grinnell), but it is not probable that the species breeds in any of these localities.

Eggs taken in British Columbia at Fort George and Fort St. James (specimens in United States National Museum) are probably the only certainly identified eggs of the species known. The bird probably breeds in British Columbia as far south as Clinton (Rhoads), and eastward across Canada, north of about the fiftieth parallel of latitude.

Winter range.-The greater yellow-legs winters to the southern end of the mainland of South America. To the north it occurs on both coasts and in Central America, Mexico, and the West Indies to the coast of 
Georgia (Helme)-occasionally to North Carolina (Bishop)-Louisiana (Edwards), Texas (Merrill), and California. In this latter State it winters on the coast north at least to Los Angeles County (Grinnell), and in the interior to Owen Lake (Fisher).

Spring migration.-The advance begins in March, and the first reach Raleigh, N. C., on the average April 3, earliest March 22, 1893 (Brimley); Long Island, New York, average April 22, earliest April 17, 1896 (Worthington); eastern Massachusetts, average April 26, earliest April 22, 1893 (Browne); southern Maine, average May 9, earliest April 26, 1896 (Morrell); city of Quebec, Canada, average April 30, earliest April 18, 1903 (Dionne); Point de Monts, Quebed, average May 5, earliest April 26, 1885 (Comeau). Lake Mistassini, Quebec, May 7, 1885 (Macoun). Some other early dates along the Atlantic coast are: Patapsco Marsh, Maryland, March 26, 1875 (Kirkwood); Carlisle, Pa., March 19, 1844 (Baird); Westport Harbor, Massachusetts, March 10, 1899 (Howe and Sturtevant). The arerage date of arrival in central Illinois is April 6, earliest March 22, 1890 (Brown); Chicago, Ill., average April 24, earliest April 14, 1895 (Blackwelder); Oberlin, Ohio, average April 18, earliest April 12, 1905 (Jones); southern Michigan, average April 27, earliest April 24, 1897 (Hankinson); southern Ontario, average April 28, earliest April 13, 1896 (Taverner); Ottawa, Ontario, average May 9, earliest April 28, 1905 (White); Keokuk, Iowa, average April 14, earliest March 26, 1893 (Currier); Elk River, Minn., average April 21, earliest April 17, 1886 (Bailey); Aweme, Manitoba, average May 4, earliest April 30, 1902 (Criddle); Kansas City, Mo., March 9, 1903 (Bryant); Manhattan, Kans., March 11, 1883 (Lantz); Lincoln, Nebr., April 10, 1899 (Wolcott); Fort Lyon, Colo., March 28, 1886 (Thorne); Loveland, Colo., March 26, 1890 (Smith); Cheyenne, Wyo., April 11, 1888 (Bond); Great Falls, Mont., April 17, 1892 (Williams); Rathdrum, Idaho, April 20, 1901 (Danby); Fort Simpson, Mackenzie, May 23, 1860 (Ross), May 16, 1904 (Preble); Chilliwack, British Columbia, March 28, 1888 and 1889 (Brooks); Fort Kenai, Alaska, May 6, 1869 (Bischoff).

Those individuals that are to breed leave the United States by the first week in June. The species is common in Chile and Argentina through the winter and to early April, when most leave for the north, but some remain the whole summer in Argentina (Holland), 6,000 miles south of the breeding range.

Eggs have been taken at Fort St. James, British Columbia, May 31, 1889 (MacFarlane), and at Fort George, British Columbia, May 20, 1890 (specimens in United States National Museum). The earliest downy young noted in 1901 in the Caribou district, British Columbia, were seen on June 15 (Brooks).

Fall migration.-Hardly six weeks elapse between the passage of the last northward-bound migrants on Long Island, New York, 
and the appearance of the first fall migrants; on the average the last in spring pass May 28, latest June 14, 1901 (Scott), while the average date of fall arrival is July 19, earliest July 10, 1887 (Scott). The larger flights there do not come until August, and the species is most common in September and October. Formerly this was one of the common species of shorebirds and one much sought by gunners. A hunter near Newport, R. I., shot 1,362 greater yellow-legs in the eight seasons 1867-1874, on dates ranging from July 20, 1870, to November 4, 1870; his highest score, 419 birds, was in 1873, from August 19 to October 19. Dates of fall arrival are: Granville, Wash., July 7, 1897 (Young); Utah Lake, Utah, July 26, 1872 (Henshaw); Aweme, Manitoba, average July 29, earliest July 27, 1901 (Criddle); Lipscomb, Tex., one June 29, common July 8,1903 (Howell); Pacheco, Chihuahua, July 30, 1905 (Brown); Toronto, Ontario, July 28, 1891 (Nash); Cullingham Cove, Ungava, July 31, 1891 (Norton); Anticosti Island, July 8, 1881 (Brewster); Erie, Pa., July 28, 1896 (Todd); Washington, D. C., July 24, 1890 (Richmond); Bahama Islands, July 6, 1904 (Allen); Barbados, West Indies, July 25, 1886 (Manning); Bonaire Island, off the coast of Venezuela, July 21, 1892 (Hartert).

Dates of the last seen are: Near Fort Churchill, Keewatin, August 8, 1900 (Preble); Hayes Run, Keewatin, August 30, 1900 (Preble); Oxford House, Keewatin, September 10, 1900 (Preble); Cumberland Sound, September 14, 1877 (Kumlien); near Fort Chimo, Ungava, September 19, 1882 (Turner); Portage la Prairie, Manitoba, October 21, 1884 (Nash); Chilliwack, British Columbia, November 17, 1888, (Brooks), November 21, 1889 (Brooks) ; Long Island, New York, average November 5, latest November 20, 1901 (Scott). The late dates of departure explain the name winter yellow-legs for this species.

\section{Yellow-legs. Totanus flavipes (Gmel.).}

Breeding range.-The principal summer home of the yellow-legs" is the Barren Grounds and neighboring regions to the southward. The species ranges north to southern Ungava (Selwyn), central Keewatin (Preble), and nearly to the Arctic coast in northern Mackenzie (MacFarlane). It breeds north to Kotzebue Sound (Townsend) and Fort Yukon (Dall and Bannister), but apparently does not occur on the northern coast of Alaska. The southern limit of the breeding range is imperfectly known; the species breeds in Yukon at least south to Lake Marsh (Bishop), and in the interior probably to southern Alberta (Macoun), southern Saskatchewan (Macoun), and northern Quebec (Macoun).

Winter range.-The yellow-legs passes south in winter to the Strait of Magellan (Gay) and occurs at this season quite generally over the southern half of South America, and even in the mountains up to 10,000 feet (Sclater). Winter records north of this region are few, and probably only a comparatively small number regularly winter 
Bul. 35, Biological Survey, U. S. Dept. of Agriculture.

Plate l.

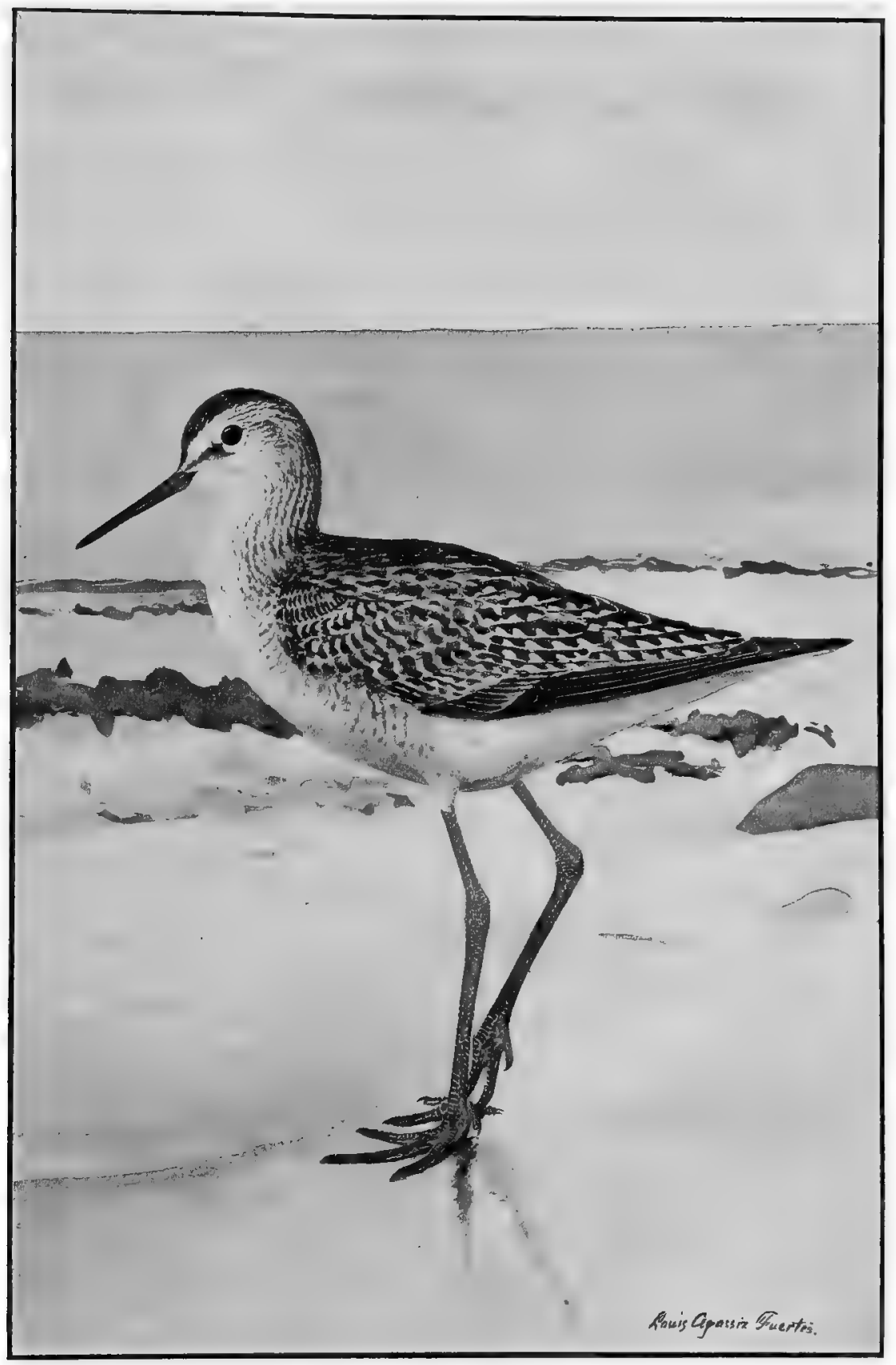

Yellowlegs (Totanus flavipes). 

north of South America. A few winter in southern Mexico, as far north as Cozumel Island. (Sharpe) and La Barca, Jalisco (Goldman); a few are noted occasionally in Louisiana (Beyer) and in Florida in winter (Pillsbury), and the species occurs rarely in the Bahamas at this season (Bonhote).

Migration range.-The yellow-legs is common on the Atlantic coast in fall and many pass through the Lesser Antilles. In this latter region it is practically unknown in spring, and it is rare in spring migration on the Atlantic coast north of Long Island, New York. These facts would seem to indicate that some yellow-legs pursue different migration routes in fall and spring. The species is a common migrant in the Mississippi Valley both spring and fall, and hence probably most of those that go south through the Lesser Antilles return in spring to their breeding grounds by way of the Mississippi Valley.

The species is not common on the Atlantic coast north of the Gulf of St. Lawrence, though one was taken October 8, 1882, near Fort Chimo, Ungava (Turner), and two have been taken in southern Greenland (Winge).

The yellow-legs is rarely seen west of the Rocky Mountains, but a few occur along the coast from northern Alaska (Grinnell) to southern Lower California (Brewster). One was taken June 11, 1890, on St. Paul Island (Palmer).

Spring migration.-The following dates show the usual time at which the yellow-legs arrives in its northward migration: Northern Texas, average March 26, earliest March 22, $1899^{\circ}$ (Mayer); central Missouri, average April 14, earliest April 9, 1903 (Bryant); Keokuk, Iowa, average April 16, earliest March 11, 1894 (Currier); central Nebraska, average April 28, earliest March 27, 1900 (Wolcott); Chicago, Ill., average April 23, earliest April 15, 1899 (Gault); Oberlin, Ohio, average April 28, earliest April 23, 1904 (Jones); Raleigh, N. C., average April 1, earliest March 25, 1893 (Brimley). The following are dates of occurrence somewhat earlier than the average: Cumberland, Ga., March 12, 1902 (Helme); Washington, D. C., March 12, 1906 (Green); Havre de Grace, Md., March 15, 1895 (Kirkwood); near Newport, R. I., April 28, 1902 (King); Godbout, Quebec, May 5, 1888 (Comeau); San Antonio, Tex., March 20, 1903 (Norton); Bay St. Louis, Miss., March 13, 1902 (Allison); Sioux City, Iowa, March 11, 1864 (Feilner); southern Ohio, March 18, 1901 (Henninger); Lanesboro, Minn., April 7, 1890 (Hvoslef); Fort Lyon, Colo., March 30, 1886 (Thorne); Indian Head, Saskatchewan, April 25, 1892 (Macoun); Edmonton, Alberta, May 1, 1901 (Preble); Fort Reliance, Yukon, May 3 (Nelson); Fort Resolution, Mackenzie, May 5, 1860 (Kennicott); Willow River, Mackenzie, May 9, 1904 (Mills and Jones); Fort Reliance, Mackenzie, May 13, 1834 (Back); Fort 
Franklin, Mackenzie, May 16, 1826 (Richardson); Fort Anderson, Mackenzie, May 27, 1865 (MacFarlane). The yellow-legs is thus about the earliest shorebird to reach high northern latitudes.

Eggs were taken at Fort Resolution June 1, 1860 (Kennicott); near Fort Anderson, June 15, 1863, June 20, 1864, and June 16, 1865 (MacFarlane); and downy young July 1, 1899, at Lake Marsh, Yukon (Bishop).

Fall migration.-Like so many other waders, the yellow-legs begins its southward journey early in July, so early indeed that migrants have appeared on the Bermudas by July 13 (Reid). Other dates of. fall arrival are: Chilliwack, British Columbia, July 25, 1889 (Brooks); Fort Lyon, Colo., July 23, 1884 (Thorne); Aweme, Manitoba, July 26, 1901 (Criddle); Toronto, Ontario, July 18, 1891 (Nash); near Chicago, Ill., July 3, 1893 (Dunn), abundant by July 25 (Parker); Long Island,'New York, July 14, 1887 (Scott), July 9, 1905 (Latham); Long Beach, New Jersey, July 9, 1877 (Scott); James Island, Florida, July 20, 1901 (Williams); Key West, Fla., July 16, 1888 (Scott); Inagua, Bahamas, July 28, 1891 (Cory); Jamaica, August 2, 1891 (Field); the average date of arrival in the Lesser Antilles is about July 25, earliest July 4, 1888 (Feilden); Santo Domingo, Venezuela, July 24, 1903 (Briceno); Fortin Page, Argentina, September 13, 1890 (Kerr). The yellow-legs is one of the earliest birds to migrate in fall, and the greater number have left the breeding grounds by the latter part of August. A few linger quite late, as shown by the following dates of the last seen: Near Fort Chimo, Ungava, October 8, 1882 (Turner); Montreal, Canada, October 7, 1898 (Wintle); Scotch Lake, New Brunswick, October 28, 1901 (Moore); Ottawa, Ontario, October 18, 1901 (White); Lanesboro, Minn., October 11, 1888 (Hvoslef); Oberlin, Ohio, October 18, 1899 (Jones); Long Island, New York, October 18, 1905 (Latham); Erie, Pa., October 14, 1893 (Todd); Lincoln, Nebr., November 17, 1900 (Wolcott).

Solitary Sandpiper. Helodromas solitarius (Wils.).

Breeding range.-Few facts are known concerning the breeding range of this species. It has been seen in summer over a great extent of country; the young only a few days old have been noted in widely separated localities, but the nest and eggs are almost unknown. The species as a whole, including the eastern and western forms, ranges north in summer to Newfoundland (Reeks); Fort Chimo, northern Ungava (Turner); Great Bear Lake, Mackenzie (Richardson); and to Kowak River, in northwestern Alaska (Grinnell). The southern limit of the breeding range is entirely undetermined. The birds stay in summer as far south as Pennsylvania (Todd), Illinois (Ridgway), Nebraska (Cary), Colorado (Cooke), and Washington (Dawson).

Winter range.--There seem to be no winter records whatever of the western form of the solitary sandpiper. There is every reason 
for believing that it winters in South America, and has not been distinguished there from the eastern form. The following statement of the winter range doubtless includes both forms, but it is not safe to conclude that the eastern form goes to eastern South America and the western form to the Pacific coast. It is known that the eastern form migrates to the Pacific coast of Mexico, and it is probable that thence southward the two forms commingle both in migration and during the winter. The species as a whole ranges south in winter to Buenos Aires, Argentina (Barrows); to Caiza, in southeastern Bolivia (Salvadori); and to Chorillos, central Peru (Taczanowski). It occurs regularly also at this season in northern South America to Guiana (Quelch), Venezuela (Berlepsch and Hartert), and Colombia (Salvin and Godman). North of South America it is not common anywhere in winter, and it may not winter at any of the following places, but it has been noted as late as December in Porto Rico (Bowdish), Costa Rica (Todd), Yucatan (Sharpe), Veracruz (Sharpe), and northern Lower California (Stephens).

Migration range.-A specimen was taken in Greenland August 1, 1878 , at Kangek, latitude $64^{\circ}$ (Hagerup); and one of the eastern form was taken October 28, at San José del Cabo, Lower California (Brewster).

Spring migration.-The following records include both the eastern and western forms: The species arrives in the southern United States in March; Tallahassee, Fla., March 25, 1901 (Williams); Coosada, Ala., March 28, 1878 (Brown); Bay St. Louis, Miss., March 17, 1902 (Allison); New Orleans, La., average March 16, earliest March 5, 1900 (Allison); Boerne, Tex., March 25, 1880 (Brown); while some of the earliest records in California are at Los Angeles, April 21, 1897 (Grinnell), and Gridley, April 23, 1891 (Belding). Further progress northward is decidedly slow, as shown by the following dates of arrival: Raleigh, N. C., average April 24, earliest April 4, 1889 (Brimley); near Asheville, N. C., average April 22, earliest April 9, 1890 (Cairns); Washington, D. C., average April 28, earliest April 25, 1900 (Preble); Englewood, N. J., average April 30, earliest April 28, 1900 (Lemmon); near New York City, average May 4, earliest April 30, 1899 (Thayer); Renovo, Pa., average May 4, earliest May 1, 1897 (Pierce); eastern Massachusetts, average May 6, earliest May 2, 1891 (Long); southwestern Maine, average May 11, earliest April 28, 1903 (Swain); Petitcodiac, New Brunswick, May 14, 1887 (Willis); Pictou, Nova Scotia, May 7, 1894 (Hickman); Lake Mistassini, Quebec, May 23, 1885 (Macoun); central Iowa, average April 25, earliest April 10, 1899 (Savage); Chicago, Ill., average April 23, earliest April 7, 1887 (Coale); Bloomington, Ind., average May 2, earliest April 23, 1903 (McAtee); Oberlin, Ohio, average April 29, earliest April 18, 1909 (Jones); Ottawa, Ontario, average May 11, 
earliest May 2, 1896 (White); southern Wisconsin, average May 6, earliest April 25, 1897 (Russel); Lanesboro, Minn., average May 6, earliest April 24, 1888 (Hvoslef); near San Antonio, Tex., average April 17, earliest March 25, 1880 (Brown); central Kansas, average May 2, earliest April 23, 1885 (Kellogg); Harrisburg, N. Dak., average May 5, earliest May 3, 1904 (Eastgate); Aweme, Manitoba, average May 13, earliest May 9, 1906 (Criddle); Colorado Springs, Colo., May 1, 1882 (Allen and Brewster); Terry, Mont., May 7, 1903, May 9, 1904 (Cameron); Athabaska Landing, Alberta, May 5, 1901 (Preble); Sandy Creek, Alberta, May 14, 1903 (Preble); Fort Providence, Mackenzie, May 14, 1905 (Jones); Fort Simpson, Mackenzie, May 10, 1904 (Preble); Great Bear Lake, May 14, 1826 (Richardson); Fort Steilacoom, Wash., May 6, 1856 (Suckley); Chilliwack, British Columbia, May 7, 1888 (Brooks); Nulato, Alaska, May 15, 1867, May 18, 1868 (Dall); Kowak River, Alaska, May 18, 1899 (Grinnell).

One of the parties of the Biological Survey took downy young June 23, 1903, at Charlie Creek, Alaska (Osgood); eggs are reported from central Alberta, June 24, 1908, June 15, 1908, June 1 and June 9, 1909 (Thayer and Arnold), and young in the nest were found June 19, 1908, at Stony Plain, Alberta (Stansell).

Fall migration.--Early dates in the fall south of the breeding range are: Washington, D. C., average July 21, earliest July 15, 1899 (Howell); Raleigh, N. C., average July 25, earliest July 14, 1894 (Brimley); Key West, Fla., July 28, 1888 (Scott); New Orleans, La., July 20, 1899 (Kopman); Kerrville, Tex., July 20, 1903 (Lacey); Camp Apache, Ariz., July 29, 1873 (Henshaw); Bermudas, July 19, 1874 (Reid); St. Croix, West Indies, July 26, 1857 (Newton); San José del Cabo, Lower California, August 25, 1887 (Brewster); near Buenos Aires, Argentina, August 20, 1880 (Barrows).

Dates of the last seen are: Chilliwack, British Columbia, September 13, 1889 (Brooks); Aweme, Manitoba, September 18, 1904 (Criddle); Chicago, Ill., October 6, 1899 (Gault); Lincoln, Nebr., October 20, 1900 (Wolcott); Ottawa, Ontario, October 31, 1906 (White); Hillsboro, Iowa, October 20, 1899 (Savage); Delavan, Wis., October 20, 1892 (Hollister); Lexington, Ky., October 23, 1904 (Dean); Pictou, Nova Scotia, October 8, 1894 (Hickman); Scotch Lake, New Brunswick, October 5, 1901 (Moore); southwestern Maine, October 21, 1904 (Norton); Renovo, Pa., October 14, 1897 (Pierce); Chesapeake Beach, Md., November 2, 1906 (Riley); Beaver, Pa., November 28, 1901 (Todd).

Western Solitary Sandpiper. Helodromas solitarius cinnamomeus (Brewst.).

The western solitary sandpiper-occurs in western North America and ranges at least as far east as Great Slave Lake (Preble), Athabaska Lake (Preble), the eastern foothills of the Rocky Mountains 
in Colorado (Henshaw), and to central Texas (Gaut). It migrates throughout western Mexico and east to Veracruz (Sartorius) and Tehuantepec (Sumichrast). As already stated, the winter range has not yet been determined.

\section{Green Sandpiper. Helodromas ocrophus (Linn.).}

The green sandpiper, an Old World species, is widely distributed breeding from the Pyrenees to southern Siberia, principally in the mountains. It winters from southern Europe and Japan, throughout Africa, and to Ceylon. It is supposed to have occurred at Halifax, Nova Scotia (Harting), and in the Hudson Bay Company's territory (Nuttall), but the evidence is not conclusive.

Wood Sandpiper. Rhyacophilus glareola (Linn.).

The wood sandpiper is one of the best known of the Oid World sandpipers. It breeds over most of Europe and Asia from the valley of the Danube and northern China to the Arctic coast. It winters from the Mediterranean and India to southern Africa and the Malay Archipelago. The only record of the species in North America is that of a single specimen taken May 27, 1894, on Sanak Island, Alaska (Littlejohn).

\section{Willet. Catoptrophorus semipalmatus (Gmel.).}

Breeding range.-The breeding range of the willet on the Atlantic coast has become much restricted of late years. Formerly it bred north, commonly to New Jersey (Giraud), and rarely to Sable Island (eggs in United States National Museum), Yarmouth (Bryant), and Halifax (Brewer), Nova Scotia. It still breeds rather commonly on the islands off the coast of Virginia (Dutcher), and a few may breed in extreme southern New Jersey, but probably at present no willets breed between there and Nova Scotia, where in 1903 it was reported abundant at Barrington (Trotter). It breeds along the south Atlantic coast to Florida (Scott), and throughout the Bahamas (Bonhote.)

Winter range.-On the Pacific coast it migrates in winter to Santa Lucia, southern Peru (Taczanowski), and on the Atlantic coast to the Amazon River (Pelzeln). It occurs also in winter in northern South America (Quelch), the Lesser and the Greater Antilles, the Bahamas (Bonhote), Florida (Worthington), and casually in South Carolina (Hoxie).

Spring migration.-The willet starts north in March. Some dates of spring arrival are: Hog Island, Virginia, average April 12, earliest April 7, 1888 (Doughty); southern New Jersey, average April 19, earliest April 6, 1877 (Scott); Erie, Pa., April 24, 1902 (Todd). The species has been recorded in migration to Newfoundland (Reeks), but it is not known to breed on that island.

Eggs have been taken in the Bahamas from May 15 (Cory) to July 6 (Allen); Sapelo Island, Georgia, April 22, 1888 (specimens in 
United States National Museum); Beaufort, N. C., May 8 (specimens in United States National Museum); Cobbs Island, Virginia, May 25, 1875 (Baily); Warner House, N. J., May 19, 1884 (Bellows); Madison, Conn., June 5, 1873 (Merriam); and on Sable Island in June (specimens in United States National Museum).

Fall migration.-A gunner who shot for the market near Newport, R. I., obtained 106 willets during eight seasons, 1867-1874, on dates ranging from July 11, 1871, to September 19, 1869 (Sturtevant). One bird was seen July 2, 1902, at Sakonnet, R. I. (King). The average date of arrival of late years on Long Island, New York, has been August 13, earliest August 4, 1901 (Scott). The last was seen at Plymouth, Mass., October 4, 1852 (Browne); Long Island, New York, September 24, 1905 (Latham); southern New Jerseý, average September 9, latest October 17, 1885 (Crane); Hog Island, Virginia, November 1, 1886, and October 27, 1887 (Doughty).

\section{Western Willet. Catoptrophorus semipalmatus inornatus (Brewst.).}

Breeding range.-The western willet breeds on the coasts of Texas (Merrill) and Louisiana (Beyer) and from northern Iowa (Berry), southern South Dakota (Cheney), and northern California (Beckwith; Christie), north to the southern portions of Manitoba (Thompson), Saskatchewan (Ferry), Alberta (Macoun), and to central Oregon (Bendire).

Winter range.-The western willet winters on the coasts of Louisiana (Beyer) and Texas (Sennett) and on the coast of California north to Humboldt Bay (Townsend). In winter it ranges south into Mexico (Nelson) and probably to southern Guatemala (Salvin). It also passes eastward and winters on the Gulf coast of Florida (Scott).

Spring migration.-Dates of spring arrival are: Stotesbury, Mo., April 8, 1894 (Surber); Keokuk, Iowa, April 30, 1892 (Currier); Lanesboro, Minn., April 26, 1879 (Hvoslef); central Kansas, average April 30, earliest April 28, 1883 (Lantz); northern Nebraska, earliest May 5, 1893 (Bates); northern North Dakota, average May 3, earliest May 1, 1901 (Eastgate); Indian Head, Saskatchewan, May 6, 1892 (Macoun); northern Colorado, average May 1, earliest April 27, 1887 (Smith); Cheyenne, Wyo., average May 4, earliest April 30, 1888 (Bond); Salt Lake City, Utah, April 28, 1897 (Young); Lewiston, Mont., May 2, 1903 (Silloway); Red Deér, Alberta, May 12, 1892 (Farley); Halleck, Nev., May 5, 1871 (specimen in United States National Museum); Fort Klamath, Oreg., April 22, 1887 (Merrill).

Eggs have been taken at Corpus Christi, Tex., May 17, 1882 (Goss); near Turtle Mountain, Manitoba, May 23, 1883 (Thompson); Oneida County, Idaho, May 21, 1879 (Anderson); near Beckwith, Calif., May 28, 1891 (Christie); Camp Harney, Oreg., May 8, 1878 (Bendire); southern Saskatchewan, June 14, 1906 (Bent). Thus the nesting season is about the same throughout the whole breeding range. 
Fall migration.-In fall the western willet wanders eastward far beyond the breeding range, even to the Atlantic coast, as shown by the following records: Chicago, Ill., September 2, 1906 (Armstong and Lawson); Miller, Ind., August 14, 1897 (Woodruff); Oberlin, Ohio, September 17, 1906 (Jones); Toronto, Ontario, July 20, 1898 (Fleming); Stony Creek, Conn., August 15, 1897 (Bishop); Keokuk, Iowa, October 27, 1896 (Currier). A wanderer far north of the breeding range was taken at Victoria, British Columbia, August 18, 1898 (Fannin).

Wandering Tattler. Heteractitis incanus (Gmel.).

The first information of the breeding range of the wandering tattler was obtained in 1904 by one of the parties of the Biological Survey. A downy young was shot September 5 on Macmillan River in east central Yukon (Osgood). July 28, 1906, a pair were seen by Charles Sheldon near Mount McKinley, south central Alaska, under conditions that left no doubt that they were breeding in the immediate vicinity. It is not probable that the species breeds anywhere south of Alaska, and yet it occurs in the Hawaiian Islands every month of the year (Henshaw); on the coast of California every month from March to October (Bryant), and has been taken July 2, 1900, on the island of Guam, and July 17, 1904, on the Philippine Islands (specimens in the United States National Museum). The species ranges north to Nulato, Alaska (Dall), where it is said by the natives to breed, and occurs about as far north on the Asiatic side of Bering Sea to Plover Bay (Bean), where it was taken in fall migration.

The wandering tattler winters in lower California, the Galapagos (Sharpe), the Hawaiian Islands (Henshaw), and throughout Oceania to the New Hebrides. In migration it occurs on the Commander Islands, "along the whole western coast of North America from Mexico to Alaska, and has occurred inland, accidentally at Crater Lake, Oreg. (Bendire), and on the eastern shore of James Bay (Bell).

Spring migration begins in March, bringing the birds to the coast of California (Grinnell) by the latter part of the month. The Aleutian Islands are reached the middle of May (Nelson), and the most northern part of the range by the latter part of the month (Dall).

On the coast of central California, nearly 2,000 miles south of the breeding grounds, the first fall migrants appear with great regularity within a few days of the middle of July, and are common a few days later (Loomis). At about the same time the birds return from the interior of Alaska to the coast, and are common around Bering Sea for the next two months (Nelson). The last leave the northern part of the range about the middle of September (Nelson) and desert the Aleutians a month later (Bishop). 
Ruff. Machetes pugnax (Linn.).

Though an old World species, the ruff has been taken many times in the Western Hemisphere at widely separated localities as follows: One at Nanortalik, on the southwest coast of Greenland, (Fenckers); Toronto; Ontario, spring of 1882 (Seton); English Lake, Ind., April 12, 1905 (Deane); a specimen in the Ohio State University collection bears the label, "Northern Canada, April 28, $1877 "$ (Dawson); Licking Reservoir, Ohio, November 10, 1872 (Wheaton); Columbus, Ohio, April 28, 1878 (Jones); Grand Manan, New Brunswick, no date (Boardman); Cole Harbor, near Halifax, Nova Seotia, May 27, 1892 (Brewster); Upton, Me., September 8, 1874 (Brewster); Scarborough, Me., April 10; 1870 (Smith); Camden, Me., September 14, 1900 (Thayer); Seabrook, N. H., September 24, 1907 (Hardy); Newburyport, Mass., May 20, 1871 (Brewster); Chatham, Mass., September 12, 1880 (Grinnell); Nantucket, Mass., July, 1901 (Palmer); near Sakonnet Point, Rhode Island, July 30, 1900 (Hathaway); Point Judith, Rhode Island, August 31, 1903 (King); Long Island, New York, one in fall, 1845 (Lawrence), one in October, 1851 (Lawrence), one in May 18, 1868 (Chapman); another specimen seems to have been taken on Long Island, but the date is not recorded (DeKay); Barnegat, N. J., no date (Chapman); Four Mile Run, Va., September 3, 1894 (Palmer); Raleigh, N. C., May 6, 1892 (Brimley); Barbados Issland, one before 1848 (Schomburgk), and one in 1878 (Feilden); one in "Spanish America," which probably means near the headwaters of the Rio Negro in northern South America (Pelzeln).

It is thus seen that the ruff has been taken in this hemisphere at least 27 times. Seven of the specimens have no date recorded; 9 were secured in the spring between April 10 and May 27; the other 11 were taken in the fall from July 30 to November 10. As would be expected, most of the specimens are from near the Atlantic coast; only 5 occurred in the interior, the westernmost being the one at English Lake, Indiana.

The breeding range of the ruff is from Great Britain to central Siberia and north to the Arctic coast. The bird winters in Burma, India, and to the southern part of Africa. It has wandered east in Asia to Japan and the Commander Islands, but has not yet been detected on the western coast of America.

\section{Upland Plover. Bartramia longicauda (Bechst.).}

Breeding range.-The upland or field plover, sometimes called the Bartramian sandpiper, is one of the few shorebirds that nest commonly in the Mississippi Valley. Early in the settlement of this region, much more than half the upland plovers probably nested within the boundaries of the United States. The center of abundance during the breeding season was the prairie region from Kansas to Manitoba. 


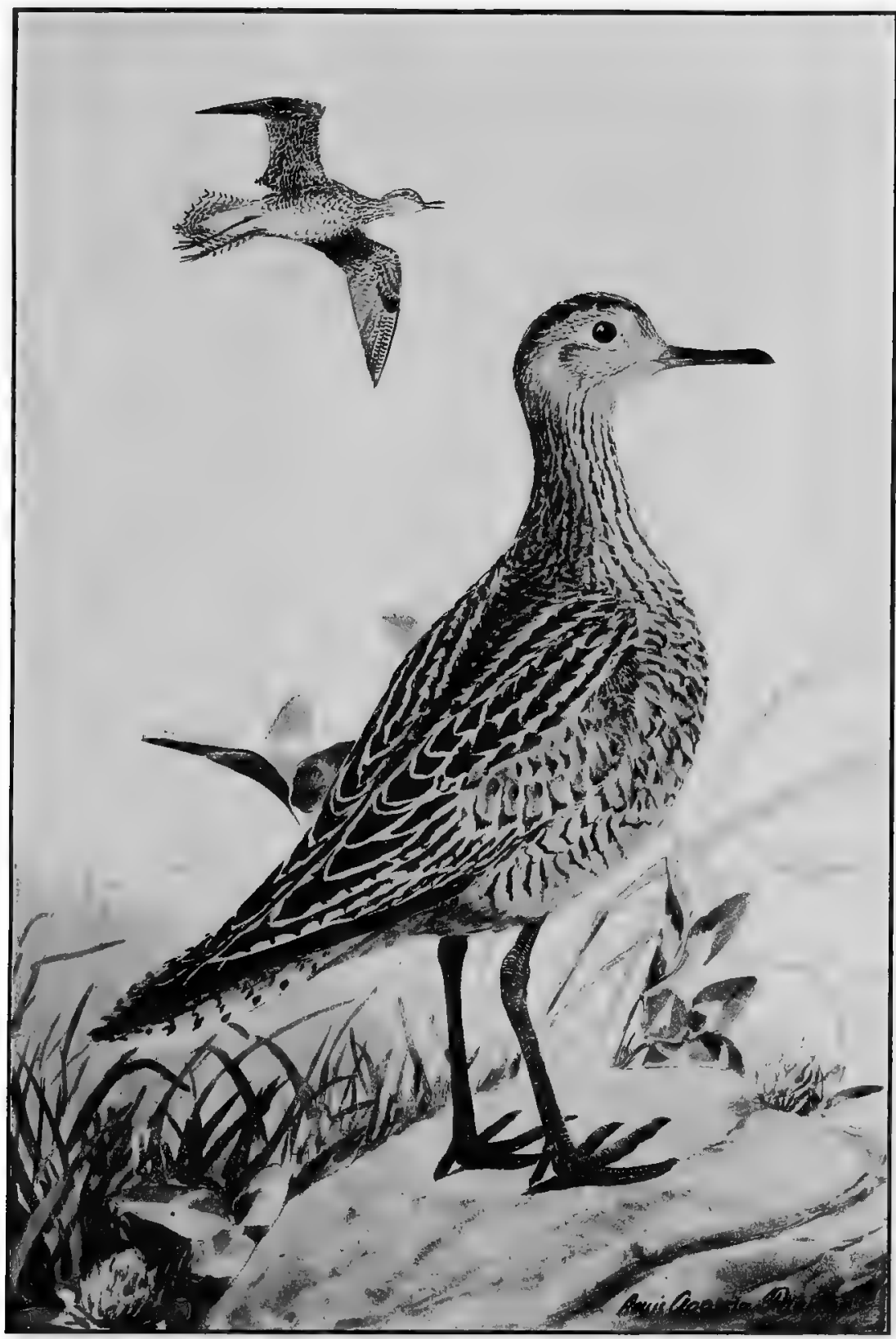

Ufland Plover (Bartramia longicauda). 

The numbers were not greatly diminished so long as this region was used for stock purposes, but recently the birds have rapidly decreased. At the present time the species breeds south to southern Oregon (Merrill); northern Utah (Ridgway); northern Colorado (Rockwell), central Oklahoma (Merrill), southern Missouri (Prior), southern Indiana (Butler), northern Virginia (Grinnan) and central Maryland (Miller). The summer range extends north to southern Maine (Norton), southern Ontario (Renfrew; Clarke), and southern Michigan (Wood). Then it bends far to the northward through central Wisconsin (Kumlien and Hollister) to central Keewatin (Cape Eskimo; Preble), southern Mackenzie (Fort Smith; Preble), northern Yukon (M'Dougall), and to the Kowak River in northwestern Alaska (Townsend). Stragglers are not uncommon in the Maritime Provinces and have occurred in Newfoundland (Reeks) and to Godbout, Quebec (Merriam). The species is not common east of Michigan nor west of the Rocky Mountains.

Winter range.-The principal winter home is in Argentina (Sclater and Hudson) and probably no upland plovers occur at this season north of the pampas of South America.

Migration range.-In fall this species passes through the Greater and the Lesser Antilles (Feilden), but in the Bahamas (Cory), Jamaica (March), and Porto Rico (Gundlach), it is so much rarer than farther east as to indicate that some individuals reach the Lesser Antilles by direct flight across the ocean. It migrates also through the Gulf States and west to Sulphur Spring, Ariz. (Henshaw), western Mexico (Durango; Nelson), and locally in Central America and the northern parts of South America.

There seem to be no spring records of migration in the West Indies east of Cuba, indicating that the individuals that go south through the Lesser Antilles return by way of Central America. Nor in spring migration is the species recorded west of central Mexico or west of the Rocky Mountains south of Utah. The only record for California is the single bird taken by Vernon Bailey of the Biological Survey at Tule Lake, August 8, 1896.

Spring migration.-The upland plover arrives in Louisiana on the average earlier than in either Florida or Texas. This would seem to prove that it reaches Louisiana by direct flight across the gulf. The average date of arrival in southern Louisiana is March 14, while the date of arrival at the same latitude in Texas is March 28, and in Florida is early April. The earliest dates are: Bonham, Tex., March 5, 1887 (Peters); New Orleans, La., March 9, 1895 (Beyer); and Tallahassee, Fla., March 25, 1901 (Williams). Other dates of arrival on the Atlantic slope are: Raleigh, N. C., average April 7, earliest March 28, 1896 (Brimley); Washington, D. C., March 21, 1896 (Richmond); Holland Patent, N. Y., average April 20, earliest 52928는 Bull. 35-10—-5 
April 14, 1896 (Williams); central Connecticut, average April 29, earliest April 16, 1896 (Jennings); southern New Hampshire, average April 30, earliest April 22, 1900 (Dearborn); Plymouth, Me., average May 3, earliest April 25, 1878 (Thorne); central Vermont, average May 5, earliest April 30,1887 (Goodwin); Godbout, Quebec, May 7, 1885 (Merriam).

Migration in the Mississippi Valley begins earlier than on the Atlantic copst and is earlier for corresponding latitudes all the way north to the Canadian boundary, as shown by the following dates of arrival: Odin, Ill., average April 4, earliest March 30, 1895 (Vandercock); Tampico, Ill., average April 11, earliest April 9, 1890 (Brown); Chicago, Ill., average A pril 16, earliest April 10, 1896 (Gault); Oberlin, Ohio, average April 14, earliest March 22, 1904 (Jones); southern Michịgan, average April 20, earliest April 8, 1895 (Alexander); central Iowa, average April 15, earliest April 3, 1893 (Ross); southern Wisconsin, average April 18, earliest April 10, 1853 (Stiles); Heron Lake, Minnesota, average April 24, earliest April 20, 1890 (Miller); Manhattan, Kans., average April 14, earliest April 4, 1882 (Lantz); Onaga, Kans., average April 14, earliest April 7, 1893 (Crevecoeur); southern Nebraska, average April 17, earliest April 6, 1890 (Wilson); northern Nebraska, average April 18, earliest April 7, 1903 (Colt); central South Dakota, average April 23, earliest April 19, 1886 (Cheney); Argusville, N. Dak., average May 5, earliest April 26, 1894 (Edwards); Larimore, N. Dak, average May 5, earliest April 26, 1888 (Eastgate); Aweme, Manitoba, average May 3, earliest April 26, 1899 (Criddle); Lake Como, Wyoming, May 5, 1879 (Williston); Rathdrum, Idaho, average May 12, earliest April 27, 1901 (Danby); Columbia Falls, Mont., average May 12, earliest April 27, 1894 (Williams); Edmonton, Alberta, May 12, 1903 (Preble); Red Deer, Alberta, May 13, 1892, May 11, 1893 (Farley); 150-mile House, British Columbia, May 16, 1901 (Brooks).

In the winter home in Argentina the northern movement begins in February, and most birds are gone by the end of March; a few stragglers remain to April (Sclater and Hudson). The species passes through Peru in March and April (Sclater and Salvin); the last was seen at Piedra Blanca, Bolivia, April 23 (Allen); at Tonantins, Brazil, May 7, 1884 (Berlepsch); Cabanas, Cuba, May 22, 1900 (Palmer and Riley); Teopisca, Chiapas, May 7, 1904 (Goldman); and New Orleans, La., May 19, 1894 (Allison).

Eggs have been secured at Lawrenceville, N. J., May 18, 1889 (Phillips); Holland Patent, N. Y., May 21, 1886 (Williams); Marthas Vineyard, Mass., May 25, 1900 (Durfee); Cornwall, Vt., May 26, 1889 (Parkhill); Philo, Ill., May 4, 1900 (Hess); Winnebago, Ill., May 10, 1864 (Tolman); near Dubuque, Iowa, May 14, 1865 (Blackburn); Beatrice, Nebr., May 16, 1895 (Pearse); near Bryant, S. Dak., May 26, 1895 (Lee); Lewistown, Mont., May 25, 1904 (Silloway); Car- 
berry, Manitoba, May 30, 1886 (Seton); southwestern Saskatchewan, May 29, 1905 (Bent).

Fall migration.-Birds were observed at Lipscomb, Tex., July 10, 1903 (Howell), and as they do not breed in that locality, these were southbound migrants. Observers easily deteet the call notes of the upland plover as it passes overhead in the darkness, and these calls are usually the first signs of the fall migration. The earliest notes in 1895 at Baltimore, Md., were heard July 3, 1895 (Kirkwood); at Washington, D. C., the first calls have been heard usually between July 10 and July 16, while in 1896 the birds were seen July 7 (Richmond). The average date of arrival in southern Louisiana is July 23, earliest July 9, 1895 (Blakemore); Gainesville, Tex., July 13, 1885 (Ragsdale); Fort Lyon, Colo., July 12, 1886 (Thorne); Sulphur Springs, Ariz., August 18, 1874 (Henshaw); Chapala, Jalisco, August 27 (Richardson); San Jose, Costa Rica, September 5, 1890 (Cherrie); Barbados, West Indies, August 12, 1886 (Manning); Cienega, Colombia, September 15, 1898 (Allen). In September they first appear on their passage through Peru (Sclater and Salvin), and are noted as arriving at their winter home in Argentina (Sclater and Hudson). The last one was seen September 6, 1903, at Big Sandy, Mont. (Coubeaux); at Fort Lyon, Colo., September 2, 1886 (Thorne); near Cape Eskimo, Keewatin, August 13, 1900 (Preble); Aweme, Manitoba, average September 6, latest September 28, 1897 (Criddle); Onaga, Kans., average September 14, latest October 15, 1896 (Crevecoeur); southern Iowa, average September 20, latest September 30, 1896 (Savage); Livonia, Mich., September 18, 1891 (Alexander); Detroit, Mich., October 20, 1902 (Swales); Chicago, Ill., average September 6, latest September 22, 1906 (Armstrong and Lawson); Lexington, Ky., October 11, 1903 (Dean); New Orleans, La., October 7, 1896 (Kopman); North River, Prince Edward Island, August 25, 1887 (Bain); Pittsfield, Me., September 22, 1895 (Morrell); Taunton, Mass., September 19, 1889 (Scudder); Germantown, Pa., October 2, 1887 (Stone); Key West, Fla., October 3, 1888 (Scott); near Atlanta, Ga., November 27, 1903 (Smith); Escondido, Nicaragua, November 26, 1892 (Richmond); San Jose, Costa Rica, November 15, 1889 (Cherrie); Davila, Panama, November 30, 1900 (Bangs).

\section{Buff-breasted Sandpiper. Tryngites subruficollis (Vieill.).}

Summer range.-The buff-breasted sandpiper is known to breed from Point Barrow, Alaska (Murdoch), to near Franklin Bay, Mackenzie (MacFarlane). It was taken in June at Repulse Bay (Rae), and undoubtedly breeds along the whole Arctic coast east to Hudson Bay. Not quite so certain is the breeding of the bird on the coast of northeastern Siberia. It was found to be quite common there near Koliuchin Bay, August 1, 1881 (Nelson), and had probably bred there, but no nests or young were found, and the individuals seen mav have been early fall wanderers from Alaskan breeding grounds. 
Winter range.-It winters in Argentina and Uruguay, south at least to Buenos Aires (Durnford) and Montevideo (Gould).

Migration range.-Many thousand miles separate the summer and winter homes of the species, and the migration route between these widely separated regions seems to be somewhat different from that of any other species. The main body of migrants follows the Barren Grounds to the shores of Hudson Bay, thence almost due south across the Mississippi Valley to the coast of Texas and through Central America to northwestern South America and diagonally across the interior of South America to Argentina.

The buff-breasted sandpiper is a rare fall migrant on the Atlantic coast: Henley Harbor, Labrador, August 20, 1860 (Coues); Port Burwell, Ungava, September 28, 1884 (Bell); Quebec, three records, August 28 (Merriam) to September (Trowbridge); Cape Elizabeth, Me., September 13, 1887 (Knight); Scarboro, Me., September 5, 1907 (Norton); several records on the coast of New England and on Long Island, the latest of which is September 11, 1904, on Long Island (Braislin). South of Long Island there are no recent records, and most of the older ones are open to suspicion. The species was seen once in April in Cuba (Gundlach), twice in the fall on Barbados (Feilden), and a record for the island of Trinidad (Leotaud) is somewhat doubtful. It is practically unknown in spring on the Atlantic coast of the United States. It is not known in the Rocky Mountain region, but on the Pacific coast it has been taken at Cape Flattery, Wash. (Newberry); in southern British Columbia (Brooks); Sitka (Bischoff), St. Michael (Nelson), and Nulato (Dall and Bannister), Alaska.

Spring migration.-Migrants appear in the interior of Brazil (Pelzeln) and in Peru (Sclater and Salvin) during March, but there are no spring migration data for the whole distance between Peru and Texas. In the State of Texas the species was noted April 22, 1887, in Refugio County (Sennett), and April 23, 1877, at Gainesville (Ragsdale). The first were seen at Fort Chipewyan, May 24, 1901 (Preble); Fort Simpson, May 29, 1860 (Ross); Yukon delta, May 30, 1879 (Nelson); St. Michael, May 31, 1880 (Nelson); Point Barrow, June 8, 1882 (Murdoch), and June 6, 1883 (Murdoch).

Eggs were taken on the Barren Grounds near Franklin Bay, June 26, 1864, and June 28, 1865 (MacFarlane); and at Point Barrow, June 18, 1883 (Murdoch).

Fall migration.-The fall migration of this species and of most other waders begins in July, and so rapidly do the birds move south that they have been noted the last of this month in Nebraska (Bruner, Wolcott, and Swenk); Gainesville, Tex., August 4, 1883 (Ragsdale); San Jose, Costa Rica, September 7, 1890 (Cherrie); and Cienega, Colombia, September 12, 1898 (Allen). The southern part of the 


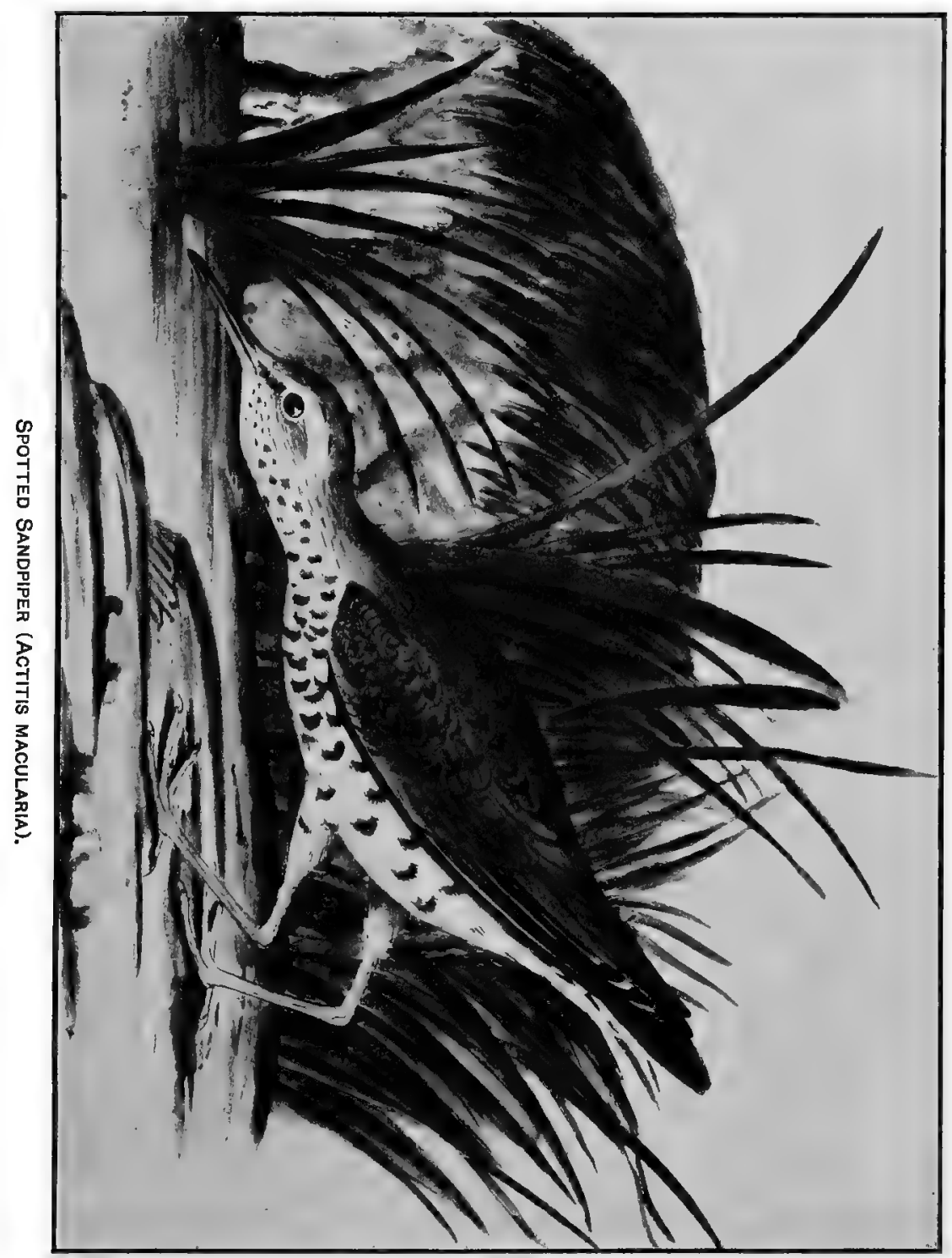



winter range in Argentina is reached early in October (Sclater and Hudson). A very early migrant was taken August 3, at Pebas, Peru (Sharpe). Usually the species is rare east of the Mississippi River, but several flocks were seen August 16-18, 1874, at Maywood, Ill., near Chicago (Fisher).

Spotted Sandpiper. Actitis macularia (Linn.).

Breeding range.-Few shorebirds have so extended a breeding range as the spotted sandpiper. It nests north to Newfoundland (Reeks), the northernmost part of Ungava (Turner), northern Mackenzie (Fort Anderson; MacFarlane), northern Alaska at Fort Yukon (Lockhart), and to the Kowak Valley in northwestern Alaska (Townsend). It breeds south to northern South Carolina (Chester County; Loomis), central Alabama (Greensboro; Avery), southern Louisiana (New Orleans; Beyer), central Texas (Lacey), southern New Mexico (Carlisle; Barrell), central Arizona (San Francisco Mountains; Mearns), and the southern Sierra of California (Walker Pass; Kaeding), and probably on the Colorado River near Needles (Hollister).

Winter range.-The spotted sandpiper ranges south in winter to central Peru (La Merced; Berlepsch and Stolzmann), central Bolivia (San Francisco; Salvadori), and to southern Brazil (Sao Paulo; Ihering). It is not rare in northern South America, and is tolerably common in Central America and Mexico; a few winter in the West Indies, and a small number in the eastern United States to the coast of Georgia (Helme) and to Port Royal, S. C. (Eaton), and in the western United States to southern Arizona (Dwight) and southern California (Grinnell).

Spring migration.-The spotted sandpiper passes north about the middle of the migration season, as shown by the following dates of arrival: Northern Florida, average March 19 (Pleas); Raleigh, N. C., average April 10, earliest April 3, 1893 (Brimley); near Asheville, N. C., average April 13, earliest April 10, 1891 (Cairns); Washington, D. C., average April 22, earliest April 2, 1905 (McAtee); near Waynesburg, Pa., average April 13, earliest April 6, 1893 (Jacobs); Beaver, Pa., average April 20, earliest. April 2, 1888 (Todd); Renovo, Pa., average April 18, earliest April 9, 1904 (Pierce); Erie, Pa., earliest April 18, 1900 (Todd); near New York City, average April 26, earliest April 15, 1891 (Burhaus); central Connecticut, average April 25, earliest April 20, $1901^{\circ}$ (Case) ; near Providence, R. I., average May 2, earliest April 21, 1905 (Mason); eastern Massachusetts, average April 28, earliest April 15, 1893 (Metcalf); Randolph, Vt., average May 5, earliest April 28, 1891 (Paine); southern New Hampshire, average May 4, earliest April 28, 1905 (Perkins) ; southwestern Maine, average May 1, earliest April 14, 1904 (Norton); Montreal, Canada, average May 13, earliest April 26, 1890 (Wintle); central New Brunswick, average May 11, earliest May 5, 1906 (McIntosh); Pictou, 
Nova Scotia, average May 7, earliest May 3, 1895 (Hickman); North River, Prince Edward Island, average May 14, earliest May 11, 1890 (Bain). The earliest date of arrival at New Orleans, La., is March 19, 1904 (Kopman); Athens, Tenn., average April 14, earliest April 10, 1906 (Gettys); Russellville, Ky., April 9, 1906 (Embody); Brookville, Ind., average April 20, earliest April 14, 1883 (Butler); Waterloo, Ind., average April 27, earliest April 5, 1895 (Hine); Chicago, Ill., average April 30, earliest April 19, 1896 (Gault); Oberlin, Ohio, average April 16, earliest April 9, 1904 (Jones); Petersburg, Mich., average April 22, earliest April 15, 1887 (Trombly); southern Ontario, average April 23, earliest April 13, 1896 (Taverner); Ottawa, Ontario, average April 30, earliest April 24, 1897 (White); southern Wisconsin, average April 27, earliest April 23, 1897 (Russell); Lanesboro, Minn., average April 28, earliest April 18, 1886 (Hvoslef); Onaga, Kans., average May 5, earliest April 26, 1896 (Crevecoeur); Aweme, Manitoba, average May 8, earliest May 2, 1905 (Criddle); Columbia Falls, Mont., average May 7, earliest May 4, 1896 (Williams); Chilliwack, British Columbia, May 9, 1889 (Brooks); Athabaska Landing, Alberta, May 6, 1901 (Preble) ; Fort Chipewyan, Alberta, May 23, 1893 (Russell); near Fort Providence, Mackenzie, May 17, 1904 (Mills); Fort Simpson, Mackenzie, May 19, 1904 (Preble); Dawson, Yukon, May 24, 1899 (Cantwell); Kowak Valley, Alaska, May 22, 1899 (Grinnell). The species has been seen south of its breeding grounds as late as May in Brazil (Pelzeln), and to the latter part of June on the northern coast of Venezuela (Robinson). The species regularly remains in Cuba (Gundlach) and the Bahamas to early May (Bonhote) and in Mexico to the latter part of the month (Sharpe). The average date of the last seen in northern Florida is May 12, and the latest May 18, 1904 (Pleas).

The date of the laying of the eggs varies but little over the whole extent of the breeding range, as shown by the following dates when the earliest eggs were found: Near Richmond, Va., May 22, 1881 (Robinson); Erie, Pa., May 24, 1893 (Todd) ; Lawrenceville, N. J., May 27, 1889 (Phillips); Trenton Falls, N. Y., May 19, 1892 (Williams); Canaan, Conn., May 16, 1887 (Tobey); Fall River, Mass., May 14, 1887 (Durfee); Orono, Me., May 24, 1894 (Knight); Montreal, Canada, June 8, 1890 (Wintle); Dunnville, Ontario, May 17, 1884 (McCallum); Big Charity Island, Michigan, May 20, 1903 (Arnold); Cheyenne, Wyo., May 30, 1889 (Bond); Fort Lapwai, Idaho, May 29, 1871 (Bendire); Fort Resolution, Mackenzie, May 23, 1860 (Kennicott); Fort Anderson, Mackenzie, June 9, 1862 (MacFarlane); Fort Yukon, Alaska, June 15, 1862.

Fall migration.-The individual taken on Barbados, West Indies, July 4, 1888 (Feilden), may have been a nonbreeding summer resident, or an early fall migrant, but by the end of July migrants have 
appeared in the Lesser Antilles, on the coast of Venezuela (Hartert), and in Mexico (Brown); indeed, in 1892 a specimen was taken in northern Lower California the first day of July (Mearns).

The last seen at Chilliwack, British Columbia, was October 9, 1888 (Brooks); average of the last seen at Columbia Falls, Mont., September 19, latest September 22, 1895 (Williams); Aweme, Manitoba, average Septémber 5, latest September 11, 1903 (Criddle); Lincoln, Nebr., September 29, 1900 (Wolcott); Lawrence, Kans., October 14, 1905 (Wetmore); Lanesboro, Minn., November 2, 1886 (Hvoslef) ; Ottawa, Ontario, average September 18, latest October 28, 1902 (White) ; southern Ontario, average September 30, latest October 25, 1902 (Saunders); Oberlin, Ohio, average September 20, latest October 30, 1905 (Jones); Scotch Lake, New Brunswick, October 5, 1901 (Moore); southwestern Maine, average October 1, latest October 6, 1900 (Johnson); eastern Massachusetts, average October 7, latest October 14, 1895 (Farmer); Hartford, Conn., average October 8, latest October 12, 1902 (Case); Ossining, N. Y., October 23 (Fisher); Washington, D. C., October 28, 1906 (Fisher); near New Orleans, La., latest November 5, 1902, November 10, 1903 (Allison).

\section{Long-billed Curlew. Numenius americanus Bechstein.}

Breeding range.-The principal summer home of the long-billed curlew is in the interior of the United States on the northern half of the plains. Southward it has been known to breed to Oklahoma (Camp Supply; Wilcox), northwestern Texas (McCauley), central New Mexico (Los Pinos; Woodhouse), southern Arizona (Sulphur Spring; Henshaw), and northwestern California in the Pit River region (Grinnell). To the northward it breeds to central British Columbia (150-mile House; Brooks), southern Alberta (Bow River; Macoun), southern Saskatchewan (Medicine Hat; Macoun), and southern Manitoba (Seton). The long-billed curlew was formerly common in the eastern part of the Mississippi Valley and abundant on the Atlantic coast, but of late years the numbers have been so reduced that now it is merely casual or accidental east of the Mississippi. There are records of the former breeding of the species in northern Iowa (Preston), Wisconsin (Hoy), southern Michigan (Jackson; Davis), and northern Illinois (Ridgway). The species was an abundant migrant on the southern Atlantic coast and less common north to Newfoundland (Reeks), and there are various surmises that it bred at various places, such as the west coast of Florida (Scott), coast of New Jersey (Wilson), and Prince Edward Island (Boardman), but most if not all of these breeding records were based on the presence of the birds in July, and there seems to be no authentic record of eggs anywhere east of Michigan.

Winter range.-The species winters on the Atlantic coast from South Carolina (Nuttall) to Florida (Allen); on the coast of Louisiana (Beyer) and Texas (Merrill); in southern Arizona (specimen in United 
States National Museum); and in California north to Owen Lake (Fisher) and San Francisco (Newberry). It also ranges south through Mexico to the Pacific coast of Guatemala at Chiapam (Salvin). It is a casual wanderer in the West Indies; Cuba, June, July, October (Gundlach); Jamaica, July, 1863 (March); St. Vincent, once in the fall (Lawrence).

Spring migration.-When the long-billed curlew was common on the Atlantic coast, it was seldom seen in spring north of the Carolinas; the few individuals that passed up the New England coast usually appeared in May: Hail Point, Maryland, May 23, 1893 (Kirkwood); Scarboro, Me., May 2, 1866 (Knight). Migration in the Mississippi Valley begins in March: Eagle Pass, March 5, 1885 (Negley); Pecos City, March 9, 1906 (Ligon); Gainesville, March 4, 1876 (Ragsdale)all in Texas; Warrensburg, Mo., April 1, 1874 (Scott); Appleton City, Mo., April 3, 1906 (Prier); central Illinois, average April 9; Jasper, Ind., April 2, 1896 (Butler); central Iowa, average April 11, earliest April 3, 1883 (Lindley); northern Nebraska, average April 3, earliest March 28, 1889 (Bates); Vermilion, S. Dak., April 5 ,1884 (Agersborg); central North Dakota, average April 15, earliest April 8, 1886 (Edwards); Aweme, Manitoba, average April 22, earliest April 9, 1902 (Criddle); Apache, N. Mex., March 25, 1886 (Anthony); Utah Lake, Utah, March 30, 1899 (Johnson); northern Colorado, average April 14, earliest April 10, 1889 (Smith); Cheyenne, Wyo., average April 18, earliest April 15, 1889 (Bond); Terry, Mont., average April 16, earliest April 7, 1906 (Cameron); Big Sandy, Mont., average April 19, earliest April 13, 1903 (Coubeaux); Fort Klamath, Oreg., March 28, 1887 (Merrill); Chelan, Wash., April 6, 1896 (Dawson); Okanagan Landing, British Columbia, April 12, 1906 (Brooks).

Eggs have been taken at Camp Harney, Oregon, April 30, 1876 (Bendire); Fort Klamath, Oreg., May 7, 1878 (Mearns); Lewistown, Mont., May 13, 1902 (Silloway); Fort Lapwai, Idaho, May 21, 1871 (Bendire); Cody, Nebr., young just hatched June 23, 1895 (Trostler); southern Saskatehewan, downy young June 1, 1905 (Bent); June 11 and 18, 1906 (Bent).

Fall migration.-Flocks of fall migrants used to appear on the Atlantic coast about the middle of July (Mearns) and reach South Carolina by early August (Hoxie). They returned to Monterey Bay, California, July 17, 1894. (Loomis), and arrived at Cape St. Lucas, Lower California, September 15, 1859 (Xantus). The last one seen at Montreal in 1893 was observed September 21 (Wintle), and on the coast of Massachusetts the species has been noted to October 18 (Howe and Allen).

Hudsonian Curlew. Numenius hudsonicus Lath.

Breeding range.-The Hudsonian curlew, or jack curlew as it is called by sportsmen, is known to breed on the barren grounds of northern Mackenzie (MacFarlane) and on the western coast of 
Alaska from the mouth of the Yukon (Nelson) north to Kotzebue Sound (Grinnell).

Winter range.-The principal winter home is on the Pacific coast, where the species ranges from Ecuador (Salvadori and Festa) to southern Chile (Chiloe Island; Pelzeln); and is especially abundant toward the southern limit of the range. At this season it occurs also on the coasts of Honduras (Taylor) and Guatemala (Salvin) and north to the southern portion of Lower California (Belding). On the Atlantic coast it occurs during the winter from British Guiana (Quelch) to the mouth of the Amazon (Sharpe).

Migration range.--The species probably does not breed in Greenland, but it has been taken several times on the western coast as far north as Jacobshaven, latitude $69^{\circ} \mathrm{N}$. (Winge). It migrates east to Ungava (Turner) and Newfoundland (Reeks), and passes down the Atlantic coast and through the Lesser Antilles to its winter home; but it is almost unknown in the Greater Antilles and in Central America and northwestern South America from Nicaragua to Venezuela. It is a common migrant and a probable breeder along the western shore of Hudson Bay (Preble), but since it is unknown in Saskatchewan and Manitoba it is evident that these Hudson Bay birds turn southeastward and probably reach the New England coast; for the bird is more common on the Massachusetts coast than would be expected from the few individuals that occur in Labrador. The species is scarcely recorded in the whole Rocky Mountain district between central Nebraska and eastern California, and it is a rare migrant in the Mississippi Valley, though a few use this route in both migrations. The main migration route is along the Pacific coast, and it occurs here west to St. Paul Island, Alaska (Palmer).

Spring migration.-Records of arrival in the eastern United States are: Sarasota Bay, Florida, March 22, 1872 (Moore); Port Royal, S. C., April 14 (Mackay); Cobbs Island, Virginia, May 19, 1891 (Kirkwood); Cape May, N. J., April 12, 1907, "ten days ahead of the usual time" (Hand); Shelter Island, N. Y., May 9, 1887 (Worthington); Nantucket, Mass., April 10, 1891 (Mackay); but usually not in Massachusetts before the middle of May. By what route these birds reach the eastern United States coast is as yet unknown, for there are no corresponding records in either the Lesser or the Greater Antilles.

The main migratory flocks reach the coast of southern California the middle of March (Grinnell) and proceeding slowly northward have been noted at Fort Kenai, Alaska, May 18, 1869 (Bischoff); Nulato, Alaska, May 12, 1866 (Pease); Kowak Valley, Alaska, May 17, 1899 (Grinnell); Fort Anderson, Mackenzie, May 29, 1865 (MacFarlane).

Eggs were taken on the barren grounds west of the lower Anderson River in late June and early July (MacFarlane), and in the Kowak Valley June 14-20, 1899 (Grinnell). 
Fall migration.--On the western shore of Hudson Bay near York Factory in 1900 the species was seen July 19, and was tolerably common in that region nearly to the first of September (Preble); the earliest date at Toronto, Ontario, is July 4, 1904 (Fleming). The average date of arrival at Nantucket, Mass., is July 20, earliest July 13 (Mackay); earliest at Long Beach, N. J., July 9, 1879 (Stone); Pea and Bodie Island, North Carolina, July 22, 1904 (Bishop); Bermudas, August 14 (Reid); Barbuda, West Indies, August 12, 1877 (Ober). Two specimens were taken July 3, 1907, at Coronado de Terraba, Costa Rica (Carriker), but these may have been nonbreeders that had not made a northern journey.

The individuals breeding in Alaska pass south along the Pacific coast, and have been noted at the Farallons, California, July 16, 1896 (Loomis); Los Coronados Islands, Lower California, August 7, 1902 (Grinnell and Daggett); Chimbote, Peru, August 2-5, 1883 (MacFarlane); and by August 18, at Arauca, Chile (Sharpe).

The Hudsonian curlew has been noted at St. Michael, Alaska, as late as September 2, 1899 (Bishop); Morro Bay, California, November, 1891 (Nelson); Great Bear Lake, August 30, 1903 (Preble); near Cape Churchill, Hudson Bay, August 24, 1900 (Preble); Henley Harbor, Ungava, August 27, 1860 (Coues). Near Newport, R. I., a gunner secured 30 birds in eight years on dates ranging from August 26, 1867, to October 2, 1874 (Sturtevant). Barbuda, West Indies, November 12, 1903 (specimen in United States National Museum).

\section{Eskimo Curlew. Numenius borealis (Forst.).}

Breeding range.-The principal summer home of the Eskimo curlew was on the barren grounds of Mackenzie, from near the Arctic coast (MacFarlane) south to Point Lake (Richardson). Thence a few ranged west as far as Point Barrow (Murdoch), but no nests seem to have been found west of Mackenzie.

Winter range.-Most of the species wintered in the campos region of Argentina (Sclater and Hudson) and Patagonia, south at least to the Chubut Valley (Durnford). It has been taken once on the Falkland Islands (Abbott). It was rare in Chile, south to Chiloe (Philippi). At present there are no data to determine the northern limit in winter, but probably few if any wintered much north of Buenos Aires.

Migration route.-The curlew left the Barren Grounds in the fall and went southeast to Labrador (Coues), where they gorged themselves for several weeks and became extremely fat. Then they passed across the Gulf of St. Lawrence and struek out to sea heading for the Lesser Antilles, nearly 2,000 miles distant. Some flocks stopped for a few days at the Bermudas (Jardine), but if the weather was fair the larger number passed on, flying both day and night, and did not land during the whole trip. When storms interfered, the birds were sometimes driven out of their course and appeared in 
considerable numbers on the coast of Massachusetts (Mackay) and less often on Long Island (Giraud) and the New Jersey coast (Turnbull). The Eskimo curlew was absent, except as a straggler, from the whole coast of the United States south of New Jersey, from the Bahamas and from the Greater Antilles. In its southward flight it passed through the Lesser Antilles (Feilden) and along the eastern portion of Brazil (Pelzeln) to its winter home. Throughout the whole line of its fall migration it was unknown in spring, at which season it was traveling northward some thousands of miles farther west over the prairies of the Mississippi Valley. The exact route between its winter home and the United States is unknown, for along the whole 4,000 miles from Argentina to northern Mexico and southern Texas the species has been recorded only twice-once in Costa Rica (Zeledon) and once in Guatemala (Salvin). Its principal migration route in spring was a comparatively narrow belt crossing the prairies on both sides of the meridian of $97^{\circ}$. The course is well known from southern Texas (Merrill) to southern South Dakota (Agersborg) and thence data are wanting. There seem to be no records of the species from about latitude $44^{\circ}$ in the Mississippi Valley until Great Slave Lake is reached, a thousand miles to the northward.

This curlew is unknown in the Rocky Mountain States or anywhere on the Pacific slope or coast south of Alaska, and the specimen taken April 8, 1892, at Lake Palomas, Chihuahua (specimen in United States National Museum), was far out of the usual course of the species. The species has been taken a few times in western Alaska, south to St. Michael (Nelson) and west to the Pribilof Islands (Palmer) and Bering Sea (specimen in United States National Museum). It has occurred accidentally several times in Éurope and on the western coast of Greenland, north to Disco Bay (Winge).

Spring migration.-The Eskimo eurlew arrived in Texas in MarchBoerne, March 9, 1880 (Brown); Gainesville, average March 17, earliest March 7, 1884 (Ragsdale); and reached central Kansas about the middle of April-April 14, 1884 (Kellogg); April 13, 1885 (Kellogg). Most of the records in the central Mississippi Valley are in April. One of the latest and most northern is that of Coues, who says that he saw them in large flocks the second week in May, 1873, between Fort Randall and Yankton, S. Dak. Then there is no further news of them until they arrived at Fort Resolution, Mackenzie, May 27, 1860 (Ǩennicott); Fort Anderson, May 27, 1865 (MacFarlane); Point Barrow, May 20, 1882 (Murdoch).

Eggs were taken at Point Lake, Mackénzie, June 13, 1822 (Richardson), and on the Barren Grounds near Fort Anderson, June 13, 1863, June 16, 1864, and June 16, 1865 (MacFarlane).

Fall migration.-The Eskimo curlew started so early in August that by the middle of the month the old birds reached the eastern 
shores of Labrador (Coues). During the following two weeks they crossed the Gulf of St. Lawrence and made their long ocean flight and by the end of another fortnight they were at the winter home in Argentina (Sclater and Hudson). Dates of arrival along this course are: Indian Tickle Harbor, Labrador, August 16, 1860 (Coues); Houlton Harbor, Labrador, August 20, 1891 (Norton); Nantucket, Mass., average August 29, earliest August 18, 1898 (Mackay); Barbados, West Indies, August 27, 1886 (Manning); Amazon River, September 4, 1830 (Pelzeln); Concepcion, Argentina, September 9, 1880 (Barrows). Some dates of the last seen are: Fort Churchill, Keewatin, September 1, 1884 (Bell); Newfoundland, to end of September (Reeks); Saybrook, Conn., October 13, 1874 (Merriam); Barbados, West Indies, November 4, 1886 (Manning). Many curlews migrated south along the west coast of Hudson Bay, before they turned east to the Atlantic and some of these seem to have wandered occasionally southward and given rise to such records as Kingston, Ontario, October 10, 1873 (Fleming); Erie, Pa., September 17, 1889 (Sennett); and a few fall records around Lake Michigan.

The Eskimo curlew is rapidly approaching extinction, if indeed any still exist. In the early sixties MacFarlane found them breeding abundantly on the Barren Grounds near Fort Anderson, while Coues reports thousands passing south along the Labrador coast in the fall; in the early seventies Coues found them equally abundant passing north through South Dakota in the spring. Ten years later they were still common in their winter home in Argentina, and naturalists who visited the Labrador coast at this time record them as present in flocks but not in numbers as seen by Coues. By 1889 only a few flocks were seen, and within the next half dozen years the flights ceased. During the last fifteen years the species has been recorded only a few times and apparently only three times in the ten years previous to 1909: Tuckernuck Island, Massachusetts, eight birds August 24, 1897 (Mackay); Nantucket, Mass., two, August 18, 1898 (Mackay); northeastern coast of Labrador, about a dozen the fall of 1900 (Bigelow). The latest records are those of two birds shot August 27, 1908, at Newburyport, Mass. (Thayer), and one September 2, 1909, at Hog Island, Maine (Knight). The disappearance of the Eskimo curlew has given rise to much speculation as to the probable cause. A simple explanation is that during recent years, especially since 1880, its former winter home in Argentina has been settled and cultivated, while its spring feeding grounds in Nebraska and South Dakota have been converted into farm land.

[European Curlew. Numenius arquatus (Linn.).

This Eastern Hemisphere species breeds from Great Britain to southern Russia, the White Sea, and the Ural Mountains. It winters in Great Britain and occurs at this season from the Mediterranean to the south end of Africa.

It is probable that one specimen of this curlew was collected on Long Island in 1853-its only North American record.] 
Whimbrel. Numenius phropus (Linn.).

Though an Old World species, the whimbrel is a common visitor in Greenland (Schalow) and possibly breeds there. It breeds in Iceland, Scandinavia, and Russia, east to the Ural Mountains and north to the Arctic Circle. It winters on the coast and islands of tropical and southern Africa, and ranges at this season east to India and the Malay Peninsula. One was taken May 23, 1906, about Tatitude $43^{\circ} \mathrm{N}$. and longitude $60^{\circ} \mathrm{W}$., south of Sable Island, Nova Seotia (Brewster).

\section{Bristle-thighed Curlew. Numenius tahitiensis (Gmel.).}

The breeding range of this species has not yet been ascertained, but in Alaska it has been taken May 18, 1869, on the Kenai Peninsula (Bischoff); May 24, 1880, at St. Michael (Nelson); August 26, 1885 , on the Kowak River (Townsend) ; and May 23, 1905, at the head of Nome River (Anthony). These dates would seem to indicate that the species nests in the northern part of its range.

The species is common on the Hawaiian Islands and occurs throughout the islands of the Pacific south to New Caledonia and from the Ladrones to the Marquesas and Paumota islands. The Pacific islands seem to be the winter home of the species, and on some of them it is quite common. It has been taken in the Phoenix group near the equator in June and July, and a few are known to remain all summer in Hawaii (Henshaw), but these apparently are nonbreeding birds.

\section{Lapwing. Vanellus vanellus (Linn.).}

Though an Old World species, the lapwing has been noted several times in Greenland on the west coast from Julianehaab to Godthaab, at various times from early December to the first of April (Schalow). It has been taken as a straggler at White Hills, Newfoundland, November 23, 1905 (Brewster); Halifax, Nova Scotia, March 17, 1897 (Piers); Merrick, Long Island, about December 26, 1883 (Dutcher); Meccox Bay, Long Island, fall of 1905 (Beebe) ; Hog Island, Bahamas, November, 1900 (Fleming); Barbados, 1886 (Cory).

The breeding range extends from Great Britain to Japan, from central Europe to the Arctic Circle, and from northern China to about latitude $55^{\circ}$ in Siberia. The species winters from about the southern limit of the breeding range to northern Africa and southern China.

Dotterel. Eudromias morinellus (Linn.).

This is an accidental visitor to North America, the only record being that of one taken July 23, 1897, on King Island, Alaska (Stone). It breeds from Great Britain, southern Russia, and eastern Siberia north to the islands of the Arctic coast. It winters from southern Europe to equatorial Africa. 
Black-bellied Plover. Squatarola squatarola (Linn.).

Breeding range.-This is a circumpolar species, but the places 'where it is known to breed are comparatively few. In North America it has been found breeding on the Melville Peninsula (Richardson), Boothia Felix (Ross), Franklin Bay (MacFarlane), and Point Barrow (Murdoch). In the Eastern Hemisphere it breeds on the Kolgnjef and Dolgoi islands of Russia and near the Taimyr Peninsula, Siberia, and probably breeds on the Liakoff Islands, Siberia, and near the south end of Nova Zembla Island.

Winter range.-The North American breeding birds pass south in winter to Chimbote and Tumbez, in northern Peru (Taczanowski), and to the Amazon River, Brazil (Pelzeln). The species is also found at this season through northern South America, the West Indies, Central America, and Mexico to the coast of South Carolina (Coues), occasionally North Carolina (Bishop), southern Texas (Sennett), and the coast of California north to Humboldt County (Townsend). It probably wintered formerly to the mouth of the Columbia (Suckley). The birds of Russia and Siberia winter from the Mediterranean, India, and southern China to southern Africa and Australia. The species is accidental in Hawaii (Henshaw).

Migration range.- The black-bellied plover has been taken several times on the west coast of Greenland north to Egedesminde, latitude $69^{\circ} \mathrm{N}$. (Winge), but probably does not breed in that country. It is known only as a migrant along the east coast of Siberia, as at Plover Bay (Nelson) and on the Commander Islands (Stejneger).

Spring migration.-The species is a late and not common migrant on the Atlantic coast in the spring, and appears in New Jersey (Stone) and on Long Island in late April and early May; Montauk, N. Y., April 30, 1902 (Scott); Cape Cod, Massachusetts, average May 23, earliest April 18, 1894 (Mackay); Pictou, Nova Scotia, May 17, 1895 (Hickman). Nor is it common in the interior, where some dates of spring arrivals are: Near New Orleans, La., March 2, 1890 (Beyer); Sedalia, Mo., March 21, 1884 (Sampson); southern Ontario, average May 27, earliest May 22 (Fleming); Vermilion, S. Dak., May 3, 1884 (Agersborg); northern North Dakota, average May 8, earliest May 5, 1894 (Bowen); Reaburn, Manitoba, average May 19, earliest May 14, 1901 (Wemyss); Cheyenne, Wyo., average May 18, earliest May 11, 1884 (Bond); Indian Head, Saskatchewan, average May 14, earliest May 9, 1904 (Lang); Fort Chipewyan, Alberta, May 23, 1901 (Preble); Fort Resolution, Mackenzie, June 2, 1860 (Kennicott); Sitka, Alaska, May 6, 1869 (Bischoff); mouth of the Yukon, May 12; Dawson, Yukon, May 20, 1899 (Bishop); Point Barrow, Alaska, June 21, 1882 (Murdoch), and June 26, 1898 (Stone).

Some individuals remain late in the spring on the Atlantic coast and possibly some nonbreeders may remain the entire summer. In Florida they have been seen June 14, June 29, July 4, July 26, and 
August 3 (Scott and Worthington). They have been seen in Jamaica in June (Field), and even off the coast of Venezuela they were common June 21-27, 1892 (Hartert). The last of the regular migrants do not leave the coast of Massachusetts until June-average June 6, latest June 15, 1886 (Cahoon); Western Egg Rock, Maine, June 24, 1895 (Knight); Toronto, Ontario, June 2 (Fleming); Corpus Christi, Tex., July 1, 1887 (Sennett).

Eggs were taken at Franklin Bay, Mackenzie, July 4, 1864, and July 8, 1865 (MacFarlane), but in each case the eggs were already partly incubated.

Fall migration.-The southward movement begins early in July, bringing a few individuals into the United States the latter part of that month-eastern Massachusetts, July 8 (Howe and Allen); Toronto, Ontario, July 23, 1890 (Fleming) - but the regular migration occurs in August: Cape Cod, Masssachusetts, average August 17, earliest August 6 (Mackay); Long Island, New York, average August 6, earliest July 1, 1905 (Kobbe); Erie, Pa., August 1, 1890 (Todd); southern Wisconsin, August 10, 1872 (Kumlien and Hollister); southern British Columbia, August 15, 1903 (Brooks). The last were seen at Winter Island on the coast of Melville Peninsula August 17, 1821 (Greely), and the first flocks came along the Labrador coast August 15, 1860 (Coues). The species was unusually abundant on Prince Edward Island in 1892 from August 22 to September 14 (Mackay). Some dates of the last seen are: Point Barrow, Alaska, August 20, 1897 (Stone); Great Bear Lake, Mackenzie, September 5, 1903 (Preble); St. Michael, Alaska, September 16, 189,9 (Bishop); southern British Columbia, October 23, 1888 (Brooks); Fort Collins, Colo., October 28, 1893 (Cooke); Lincoln, Nebr., October 21, 1899 (Wolcott); Ottawa, Ontario, average October 24, latest November 8 , 1903 (White); Pictou, Nova Scotia, October 11, 1894 (Hickman); Cape Cod, Massachusetts, average October 21, latest November 14, 1887 (Cahoon) - accidental in December, 1872 (Mackay); Erie, Pa., November 10, 1894 (Todd); Long Island, New York, average October 15, latest November 7, 1905 (Latham).

European Golden Plover. Charadrius apricarius Linn.

The combined ranges of the three golden plovers complete the circumference of the globe in the vicinity of the Arctic Circle. In general it may be said that apricarius breeds in northern Europe and northwestern Siberia; dominicus in North America; and fulvus in eastern Siberia. The ranges of apricarius and dominicus meet on the west coast of Greenland; dominicus and fulvus join ranges in western Alaska; the dividing line in Siberia between fulvus and apricarius has not yet been determined.

The European golden plover breeds from Great Britain to western Siberia and south to central Europe. It winters from about the 
southern limit of the breeding range south to Beluchistan and northern Africa. This plover has been taken as a summer visitor to the east coast of Greenland (Helms), and at several places on the west coast from the southern end to Christianshaab about $69^{\circ}$ latitude (Winge). It has not yet been found breeding in Greenland, though it has been taken there in midsummer (Helms).

Golden Plover. Charadrius dominicus Müll.

Breeding range.-The summer home of the golden plover extends from Whale Point at the northwest corner of Hudson Bay (Eifrig), west across the barren grounds to the mouth of the Anderson River (MacFarlane), and thence along the barren grounds of the coast of Alaska to Kotzebue Sound (Grinnell). It extends north in Franklin to include the islands, at least as far as latitude $77^{\circ}$. The bird is known to breed commonly on Banks Island (Armstrong), Prince Albert Island (Armstrong), Melville Island (Parry), and theislands at the north end of Wellington Channel (Belcher), and east to the eastern coast of Melville Peninsula (Parry). It probably does not breed in Greenland, though it occurs not uncommonly on the west coast to about latitude $73^{\circ}$ (Walker). There are somewhat doubtful records of the species having been seen August 7, 1881, at Cape Baird, Lady Franklin Bay, $81^{\circ} 30^{\prime} \mathrm{N}$. (Greely), and on July 12, 1872, at Thank God Harbor, Greenland, $81^{\circ} 40^{\prime}$ (Davis). As the belt of tundra along the north coast of Alaska is comparatively narrow, the principal breeding grounds of the golden plover are between the mouth of the Mackenzie River and the Gulf of Boothia, north of the Arctic Circle.

Winter range.-The species ranges south on the Atlantic coast to Bahia Blanca, central Argentina (Barrows), and the center of abundance during the winter season is the pampas of Argentina (Sclater and Hudson) and Uruguay (Aplin), between the parallels of $34^{\circ}$ and $36^{\circ} \mathrm{S}$. Individuals remain during the winter as far north as Rio Janeiro, Brazil (Hapgood), on the coast and to Cuyaba, Matto Grosso (Pelzeln), in the interior. There is one record of the occurrence of the species (probably casual) in January at Nauta in northeastern Peru (Sharpe). The golden plover does not winter in the Lesser Antilles nor in that part of northeastern South America where it is most abundant in migration. It has been recorded as wintering at several places north of South America, but probably such of these records as are not errors represent accidental or unusual occurrences.

Migration range.-From the breeding grounds the golden plover go south and southeast to Labrador; then cross the Gulf of St. Lawrence and its islands to Nova Scotia, and from the southern coast of the latter fly directly across the ocean to the Lesser Antilles and the coast of northeastern South America. Sometimes when caught by a storm during this flight they seek the nearest land, appearing not 
infrequently at the Bermudas, Cape Cod, and Long Island. After a short stop in the Antilles and northern South America, they pass to the winter home in Argentina and remain there from September to March.

The return northward in spring is by a different route, the details of which are not yet determined. What is known is that they disappear from Argentina and shun the whole Atlantic coast from Brazil to Labrador. In March they appear in Guatemala and Texas; April finds them on the prairies of the Mississippi Valley; the first of May sees them crossing our northern boundary; and by the first week in June they reappear on their breeding grounds in the frozen north.

Various theories have been advanced to account for this strange migration course. The simplest explanation seems to be the application of the following, which may be laid down as the fundamental law underlying the choice of migration routes. Birds follow that route between the winter and summer homes that is the shortest and at the same time furnishes an abundant food supply. Applying this rule to the case of the golden plover, the following facts are apparent: The plover is a bird of treeless regions; it summers on the tundras and winters on the pampas; an enormous food supply especially palatable tempts it in the fall to Labrador and furnishes power for the long flight to South America. To attempt to return in spring by the same course would be suicidal, for at that season Labrador would furnish scant provender. The plover seeks the shortest treeless route overland, and alighting on the coast of Texas travels leisurely over the Mississippi Valley prairies, which are abundantly supplied with food, to the plains of the Saskatchewan and thence to the Arctic coast.

Spring migration.-The principal line of migration from the winter home northward through South America is not yet known; the species is said to be common in March and April in Peru (Sclater and Salvin) east of the mountains, but next to nothing is known regarding its appearance in the territory for a thousand miles to the northward. The species is practically unrecorded at all seasons of the year from Ecuador, Colombia, Panama, Nicaragua, and Honduras, and though a few have been noted in Costa Rica (Cherrie), Guatemala (Sclater and Salvin), and eastern Mexico (Sclater), in none of these countries have the great flocks been seen that are so characteristic of the fall flight in the Lesser Antilles and of the spring advance up the Mississippi Valley. Not until Texas is reached can the movements of the golden plover be definitely traced, and at no place between Peru and Texas has it ever been recorded as common. In fact, the records as they stand are what they should be if the plover escapes the forested regions of northern South America and Central America by a single flight of from 2,000 to 2,500 miles from the valleys of eastern Peru to the treeless prairies of Texas. The general time of appearance in the, $52928^{\circ}-$ Bull. $35-10-6$ 
United States and of passage to the summer home can be gathered from the following dates of arrival: Boerne, Tex., March 9, 1880 (Brown); Indianola, Tex., March 15, 1856 (Cassin); Gainesville, Tex., March 17, 1885 (Ragsdale); Caddo, Okla., March 12, 1884 (Cooke); near New Orleans, La., March 24, 1894 (Allison), April 2, 1881 (Langdon); Fayetteville, Ark., abundant March 20-31, 1883 (Harvey); central Missouri, average April 13, earliest April 11, 1903 (Bryant); Badger, Nebr., average April 8, earliest April 5, 1903 (Colt); Lebanon, Ill., March 17, 1876 (Jones); Tampico, Ill., average April 10, earliest March 31, 1885 (Brown); Terre Haute, Ind., March 23, 1888 (Evermann); Chicago, Ill., average April 16, earliest March 30, 1899 (Gault); central Iowa, average April 19, earliest April 12, 1883 (Williams); Heron Lake, Minnesota, average May 1 (Miller); central South Dakota, average April 30, earliest April 25, 1888 (Bishop); Larimore, N. Dak., average May 5, earliest May 2, 1895 (Eastgate); Aweme, Manitoba, average May 4, earliest April 23, 1905 (Criddle); Indian Head, Saskatchewan, May 9, 1904 (Lang); Fort Simpson, Mackenzie, May 26, 1860 (Ross), May 19, 1904 (Preble); Fort Reliance, Yukon, May 13 (Nelson); Point Barrow, Alaska, latitude $71^{\circ}$ N., May 21, 1882 (Murdoch), May 24, 1883 (Murdoch), June 1, 1898 (Stone). The dates of arrival in the province of Franklin are: Igloolik, 69 ${ }^{\circ}$, June 14, 1823 (Parry); Boothia Felix, 70 ${ }^{\circ}$, June 4, 1830 (Ross), June 22, 1831 (Ross); Prince of Wales Strait, $73^{\circ}$, June 7, 1851 (Armstrong); Bay of Mercy, 74 ${ }^{\circ}$, June 3, 1852 (Armstrong); Winter Harbor, 75 $5^{\circ}$, June 2, 1820 (Parry); near Wellington Channel, $77^{\circ}$, June 2, 1853 (Belcher).

The latest dates recorded in the southern part of the winter range are March 12 (Aplin) and March 19 (Barrows); in the northern part of the winter home the species remains until April (Sclater and Salvin); at Chicago the average date of the last one seen is April 30, and the latest May 9, 1895 (Blackwelder). Some other late dates are: Near New Orleans, La., June 10, 1907 (Kopman); Lebanon, Ind., May 10, 1894 (Beasley); Lawrence, Kans., May 8, 1906 (Wetmore); White, S. Dak., May 27, 1889 (Partch); Aweme, Manitoba, average May 23, latest May 29, 1896 (Criddle); Fort Chipewyan, Alberta, June 1, 1893 (Russell). South of the latitude of Chicago the bulk of the spring shooting of golden plover is in April; from Iowa northward to Canada the spring shooting occurs chiefly during the first half of May.

During the spring migration the golden plover is almost entirely absent from the Atlantic coast. There are three spring records for Massachusetts (Mackay) and a few for Long Island (Giraud), the last of them many years ago. Probably most of the other scattered spring records east of the Alleghenies are errors of identification. The species is not common at any time of the year west of Texas, 
Nebraska, and Saskatchewan, and apparently is absent in spring from the whole region west of the Rocky Mountains.

Eggs were collected on the lower Anderson River, Mackenzie, June 24, 1863, June 22, 1864, and June 16, 1865 (MacFarlane); at Point Barrow, Alaska, June 22, 1882, and June 23, 1883 (Murdoch).

Fall migration.-The old birds start south in July, and those that are to make the flight from Nova Scotia to the Lesser Antilles occupy about a month in the trip from the breeding grounds to the southern coast of Nova Scotia. If fair weather prevails, the flocks of golden plover pass by the New England coast far out at sea, but severe storms are frequent at this season, and the birds are often driven to land. The average for twenty-eight years of the date of arrival of these storm-driven migrants at Nantucket, Mass., is August 25, earliest August 12, 1898 (Mackay); a still earlier date is August 7, 1852, at Plymouth, Mass. (Browne). Five times in these twentyeight years birds were seen before August 20 (Mackay). The rule on Long Island is to expect the plover with the first storm occurring after August 28 (Lawrence). The first flocks are noted in the Bermudas during the last ten days of August (Reid), and about the same time the species arrives in the Lesser Antilles (Lawrence) and even on the coast of British Guiana (Quelch). A few golden plover reach Argentina the last week in August (Sclater and Hudson) and the species has been taken in Bolivia in August (Allen), but these early couriers are exceptional, and the main flocks arrive in September.

On the west side of Baffin Bay in 1820 the last was seen September 3 (Parry); in Nova Scotia the species sometimes remains until October (McKinlay). The average date of the last one seen at Nantucket, Mass., for ten years previous to 1890 is October 2, latest October 22, 1878 (Mackay); for the years since 1890 the average date of the last seen is September 23 (Mackay). Near Newport, R. I., a market hunter shot 386 golden plover during 1867 to 1874; the dates ranged from August 14, 1868, to October 24, 1874 (Sturtevant). On Long Island the dates of the earliest and latest recorded observations of the species are August 15 and November 10 (Chrpman). In the Bermudas and the Lesser Antilles most of the birds leave in October, though some stragglers may be noted in November.

In the interior of New England the golden plover is rare in fall, though at times it is quite common on Lake Champlain. Throughout New York, Pennsylvania, and New Jersey it is usually very rare, but in 1880 and in several other years it has been common in those States. It has been seen at Erie, Pa., on dates ranging from August 20, 1896, to November 18, 1900 (Todd). South of New Jersey on the Atlantic coast, also in the Bahamas, the golden plover is almost unknown, and it is not common anywhere in the Greater Antilles west of St. Croix. 
While the greater number of golden plover migrate across the Atlantic, a few pass south in the fall through the interior of North America. The first arrival from the north noted near Fort Churchill, Keewatin, in 1900, was on August 4 (Preble). Other dates of fall arrival in the interior are: Moose Factory, Ontario, September 8, 1860 (Drexler); Aweme, Manitoba, average September 9, earliest August 10, 1904 (Criddle); Lincoln, Nebr., September 22, 1900 (Wolcott); near Toronto, Ontario, August 31, 1891 (Nash), September 1, 1898 (Nash); Point Pelee, Ontario, September 15, 1905 (Swales), September 19, 1906 (Taverner); Chicago, Ill., average September 12, earliest September 10, 1898 (Gault); Bay St. Louis, Miss., September 26, 1899 (Allison); San José, Costa Rica, October 20, 1890 (Cherrie). Probably these Mississippi Valley fall birds are the ones that are fairly common in Peru from September to November (Sclater and Salvin) and that were noted in October at Arica, Chile (MacFarlane).

The form of the golden plover that breeds on the northern and northwestern coasts of Alaska does not seem to migrate along the western coast of Alaska, but passes in general east to Mackenzie. A few individuals migrate southeast and occur in the fall as rare straglers on the Pacific slope: Sitka, Alaska, August 16, 1896 (Grinnell); Chilliwack, British Columbia, August 26, 1889 (Brooks); Port Townsend, Wash., September 9, 1897 (Fisher); Santa Cruz, Calif., October 22, 1888 (McGregor); San José del Cabo, Lower California, October 18, 1887 (Brewster).

The golden plover does not remain late in the north. The last seen on the breeding grounds at Point Barrow, Alaska, were noted August 28, 1882 (Murdoch), and August 20, 1897 (Stone). Some other dates of late occurrence are: Great Bear Lake, September 6, 1903 (Preble); Fort Simpson, September 10, 1860 (Ross); Edmonton, Alberta, September 23, 1894 (Loring); Indian Head, Saskatchewan, October 2, 1904 (Lang); Aweme, Manitoba, average October 14, latest October 16, 1901 (Criddle); near Fort Pierre, S. Dak., October 21, 1855 (Cassin); Fort Sherman, Idaho, abundant September 15-20, 1896 (Merrill); Newcastle, Colo., October 5, 1902 (Bishop); Lincoln, Nebr., November 14, 1899 (Wolcott); Lanesboro, Minn., November 2, 1889 (Hvoslef); southern Iowa, average October 27, latest November 9, 1895 (Currier); Chicago, Ill., average October 11, latest October 28, 1895 (Blackwelder); English Lake, Ind., November 9, 1891, November 15, 1892 (Butler); Ottawa, Ontario, October 31, 1906 (White); city of Quebec, Canada, November 10, 1890 (Dionne); San José, Costa Rica, December 15, 1890 (Cherrie). The golden plover is one of the shorebirds that has diminished most markedly during the last twenty years. Formerly it was enormously abundant, and many are the accounts of the countless flocks that passed in an almost continuous stream across the Gulf of 


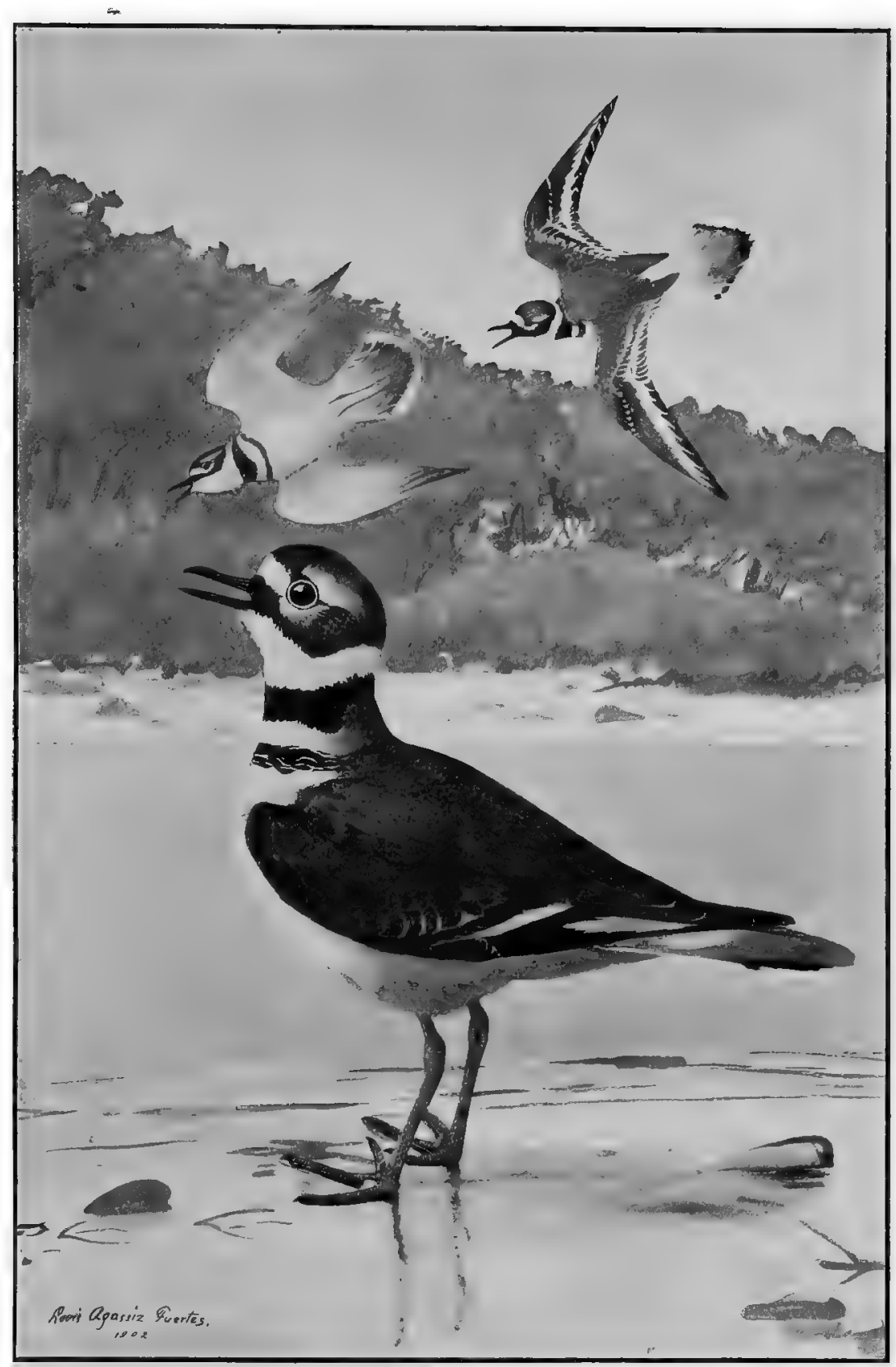

KILLDEER (OXYeCHUS VOCIFERUS). 

St. Lawrence and out to sea. On the return up the Mississippi Valley also they were abundant. For the ten years 1895-1904 the numbers reported have been so small that the species seemed in imminent danger of extinction. During 1905 and 1906, however, the species was reported from quite a number of localities, indicating that at present the comparatively small number of individuals left are holding their own. The future of the American golden plover is in the hands of the sportsmen of the Mississippi Valley. During the breeding season the birds are out of reach of danger from mankind; through the winter their welfare is out of the control of the people of the United States; but in spring during their two thousand mile journey up the Mississippi Valley, for from six to eight weeks, great numbers are slaughtered, and as a result they have diminished to a small fraction of their former numbers. If the species is to hold its own spring shooting in the Mississippi Valley must be largely curtailed or entirely abolished.

\section{Pacific Golden Plover. Charadrius dominicus fulvus Gmel.}

The principal summer home of the Pacific golden plover is in Asia, where it breeds in northern Siberia east of the Yenisei River; it breeds also on the western coast of Alaska from near Bering Strait south to Bristol Bay. It winters on the Hawaiian Islands and in China and India and south to New Zealand and Australia. Early. dates of arrival in Alaska are at Portage Bay, May 13, 1882 (Hartlaub); Kadiak Island, May 13, 1868 (Bischoff); Atka Island, May 17, 1879 (Turner). The usual time of arrival at the mouth of the Yukon is about the first of June, and the latest date in the fall is October 12 (Nelson).

\section{Killdeer. Oxyechus vociferus (Linn.).}

Breeding range.-The killdeer has one of the most extensive breeding ranges of the American shorebirds. It ranges north in summer to central Quebec (Merriam), northern Ontario (Todd), central Keewatin (Preble), southern Mackenzie (Preble), and to about latitude $53^{\circ}$ in the interior of British Columbia. The killdeer was soen at Fort Churchill, Keewatin, and at Fort Resolution, Mackenzie, by parties of the Biological Survey, and these observations very materially extend its previously known northern range. The breeding range of the killdeer extends much farther south than that of other northern breeding shorebirds. The species breeds not only throughout the whole of the United States, but south to Cape St. Lucas, Lower California (Xantus), and to Rio Sestin, Durango (Miller). Killdeers occur in Newfoundland in the fall (Reeks), but are not known to breed on that island.

Winter range.-The winter range is much less extensive than the summer. Though there are records of the presence of the species in 
Paraguay (Sharpe) and Chile (Salvin), it is probable that these represent casual occurrences and that regularly the species ranges to the Bermudas (Jardine), throughout the West Indies and the neighboring northern coast of Venezuela (Ernst), but not farther east or south on the Atlantic coast; while on the Pacific it regularly passes south to northwestern Peru (Sclater and Salvin) and the interior of Colombia and Medellin (Sclater and Salvin). The northern winter range extends regularly to North Carolina .(Brimley), Tennessee (Gettys), central Texas (Brown), rarely southern Arizona (Mearns), and throughout most of the southern half of California (Fisher). Casual occurrences have been noted in Maryland (Stabler), Pennsylvania (Burns), and Rhode Island (Mearns): After the great storm of November, 1888, which carried large numbers of killdeer to the New England coast several weeks later than the usual time for their disappearance from that part of their range, many of these birds failed to undertake a second southward migration and remained on the coasts of Massachusetts (Torrey), New Hampshire (Chadbourne), and southwestern Maine (Brown). Most of them perished during the winter, but on the Massachusetts coast a few managed to endure. An occasional killdeer passes a mild winter in southern Ohio (Jones), southern Indiana (McAtee), or on the Pacific coast to Washington (Johnson).

Spring migration.-The killdeer is among the earliest migrants among shorebirds, and is not far behind the earliest migrating land birds. Its loud, piercing, oft-repeated calls make its identification easy, and many data have been accumulated concerning the time of its migrations. These begin in February in the northern part of the winter range, and during that month many crowd northward to the limit of unfrozen ground. Such birds arrive on the average near Asheville, N. C., February 22, earliest February 18, 1893 (Cairns); central Kentucky, February 25, earliest February 19, 1906 (Embody); Brookville, Ind., February 23, earliest February 15, 1890 (Butler). The early days of March find the killdeer in full migration far beyond its winter home, and its arrival has been noted as follows: Variety Mills, Va., average March 13, earliest March 2, 1888 (Micklem); White Sulphur Springs, W. Va., average March 9, earliest March 2 1891 (Surber); Washington, D. C., average March 18, earliest February 14, 1908 (Hollister); Waynesburg, Pa., average March 8, earliest February 24, 1891 (Jacobs); Berwyn, Pa., average March 14, earliest January 29, 1889 (Burns); Branchport, N. Y., average March 19, earliest March 1, 1890 (Burtch); Jewett City, Conn., average for twenty-one years March 17, earliest March 2, 1888 (Jennings); central Rhode Island, average March 19, earliest February 27, 1902. Even as far north as Rhode Island, the killdeer is so rare that a market gunner near Newport (Sturtevant) secured only three during eight years while shooting several thousand shorebirds. 
There seems to be a section west of the Allegheny Mountains in which the killdeer arrives earlier than at corresponding latitudes either east or west. The average date of arrival at Waterloo, Ind., is March 5 (Link); Oberlin, Ohio, March 5 (Jones); Livonia, Mich., March 10 (Alexander); and Petersburg, Mich., March 10 (Trombly). Near there in Pennsylvania, on the western side of the mountains, the date of arrival at Waynesburg has already been given as March 8 (Jacobs). At the same latitude in Pennsylvania east of the mountains the killdeer arrives a week later, while to the westward of Indiana the retardation of migration is shown by the following dates of arrival: Central Missouri, average March 12, earliest February 4, 1890 (Bush); southern Iowa, average March 12, earliest March 2, 1906 (Davison); southern Wisconsin, average of thirty years March 15, earliest March 2, 1887 (Welman); Chicago, Ill., average of sixteen years March 21, earliest February 28, 1895 (Woodruff). Farther north in Ontario, as the killdeer nears the limit of its breeding range, the arrival is much delayed; southern Ontario is not reached on the average until March 23, earliest March 7, 1903 (Smith), while the average date at Ottawa, Ontario, is April 17, earliest March 18, 1894 (White). Dates of arrival farther west are: Manhattan, Kans., average March 8, earliest F.ebruary 27, 1882 (Lantz); Onaga, Kans., average March 4, earliest February 23, 1891 (Crevecoeur); Syracuse, Nebr., average March 10, earliest February 26, 1902 (Hunter); central South Dakota, average March 24, earliest March 20, 1889 (Cheney); Lanesboro, Minn., average March 29, earliest March 13, 1889 (Hvoslef); Argusville, N. Dak., average April 7, earliest March 31, 1893 (Edwards); Larimore, N. Dak., average April 7, earliest April 3, 1893 (Eastgate); southern Manitoba, average April 5, earliest March 24, 1902 (Criddle); Qu'Appelle, Saskatchewan, average April 16, earliest April 8, 1903 (Wemyss); two seen June 25, 1903, at Fort Resolution, Mackenzie (Preble).

The advance in the Rocky Mountains is not so late comparatively as in most species: Cheyenne, Wyo., average March 21, earliest March 16, 1889 (Bond); Rathdrum, Idaho, average March 30, earliest February 19, 1902 (Danby); Terry, Mont., average April 6, earliest March 29, 1897 (Cameron); Big Sandy, Mont., average April 6, earliest April 3, 1904 (Coubeaux); Red Deer, Alberta, April 11, 1893 (Farley); Portland, Oreg., February 27, 1900 (Nicholas); Grays Harbor, Washington, February 16, 1892 (Lawrence); southern British Columbia, February 28, 1888 (Brooks). South of the breeding grounds the last was seen at San José, Costa Rica, March 12, 1890 (Cherrie), and at Sisal, Yucatan, May 9, 1865 (Schott).

The date of nesting seems to bear little relation to the latitude. Eggs have been taken at Cape St. Lucas, Lower California, May 9, 1860 (Xantus); Monterey, Calif., March, 1867 (Day and Spencer); 
Variety Mills, Va., April 12, 1886 (Micklem); Laurel, Md., just hatching April 24, 1897; Erie,Pa., April 7, 1888 (Todd) ; Canandaigua, N. Y., April 23, 1879 (Howey); Bloomington, Ind., April 12, 1903 (McAtee); Kingston, Ontario, May 1, 1905 (Beaupre); Eagle Pass, Tex., March 18, 1884 (Negley); Corvallis, Oreg., downy young late April (Woodcock); Tacoma, Wash., April 14, 1908 (Bowles); Edmonton, Alberta, eggs May 19, 1897 (Macoun).

Fall migration.-The few records of fall arrival south of the breeding range show that the killdeer is one of the late migrants. It was noted in Porto Rico, October 18, 1899, and October 7, 1900 (Bowdish); San José, Costa Rica, October 15, 1891 (Cherrie); and on the coast of Peru, October 24, 1867 (Sclater and Salvin).

The last noted in southern British Columbia was November 28, 1888 (Brooks); Aweme, Manitoba, average September 23, latest September 30, 1901 (Criddle); Onaga, Kans., average October 22, latest November 8, 1896 (Crevecoeur); Lincoln, Nebr., latest November 18, 1900 (Wolcott); Delavan, Wis., November 6, 1894 (Hollister); southern Iowa, average November 10, latest December 25, 1886 (Houghton); Chicago, Ill., average October 21, latest November 13, 1885 (Holmes); southern Michigan, average November 1, latest November 13, 1891 (Alexander); Ottawa, Ontario, average September 11, latest October 16, 1905 (White); southern Ontario, average October 19, latest November 10, 1900 (Saunders); Wauseon, Ohio, average November 9, latest November 23, 1891 (Mikesel); Waterloo, Ind., average November 7, latest November 21, 1905 (Link); Montreal, Canada, September 1, 1895 (Wintle); Phillips, Me., October 24, 1905 (Sweet); Block Island, R. I., November 5, 1889 (Dodge); Branchport, N. Y., November 29, 1896 (Stone); Suffield, Conn., November 16, 1887 (Smith); Erie, Pa., November 26, 1891 (Todd); Berwyn, Pa., average November 3, latest November 22, 1886 (Burns); Bloomington, Ind., December 12, 1885 (McAtee); St. Louis, Mo., December 18, 1887 (Widmann).

[Santo Domingo Killdeer. Oxyechus vociferus torquatus (Linn.).

The Santo Domingo killdeer is the resident form of the West Indies, breeding in Cuba, the Isle of Pines, Jamaica, and Haiti, and probably also in Porto Rico.]

Semipalmated Plover. Agialitis semipalmata (Bonap.).

Breeding range.-The present known summer home of the semipalmated plover extends north to Cumberland Sound (Kumlien), Melville Peninsula (Parry), Wellington Channel (Greely), and Melville Island (Parry). The occurrence of the species at these two latter places, latitude about $75^{\circ} \mathrm{N}$., makes it probable that it occurs equally far north on the western side of Baffin Bay. It is common on the arctic coast of America as far west as the mouth of the Mackenzie (MacFarlane). Thence westward it seems to be rare on the northern coast of Alaska (Nelson), but is tolerably common in Kotzebue 
Sound (Townsend). It seems to be more common in the middle Yukon Valley (Bishop) than on the coast.

This plover breeds south to Sable Island (Dodd); southern New Brunswick (Cheney); the Magdalen Islands (Brewster); southern James Bay (Todd); York Factory, in southern Keewatin (Preble); probably rarely in northern Manitoba (Macoun); on the Slave River of southern Mackenzie (Preble); Lake Marsh, southern Yukon (Bishop); and to the mouth of the Yukon, Alaska (Dall and Bannister).

Winter range.-The species winters on both coasts of South America-south to Port Desire, $48^{\circ} \mathrm{S}$. (Seebohm), on the east coast, and to central Chile (Schalow) on the west; thence through northern South America, Central America, and the West Indies to the southern Bahamas (Bonhote), Florida (Worthington), the coast of Georgia (Helme), South Carolina (Kendall), Mississippi (Allison), and Louisiana (Beyer); on the Pacific coast of Mexico, north to southern Lower California (Brewster). In winter it is thus one of the most widely distributed of the shorebirds.

Migration range.- The species is a common migrant in eastern North America west to the eastern parts of Texas (Beckham), Nebraska (Wolcott), and Saskatchewan (Macoun). Thence over the plains and throughout the whole Rocky Mountain district it is almost unknown, but reappears on the Pacific Coast, and ranges west in migration to the central Aleutian Islands (McGregor), the Pribilof Islands (Prentiss), and even occasionally across Bering Strait to the coast of Siberia (Nelson).

Spring migration.-At least four-fifths of the dates on the spring migration of this species fall in May. This is true for the entire district between the winter and summer homes, and the dates indicate that the migration in the United States occurs chiefly between May 10 and June 1. An unusually early individual was taken April 7, 1875, at Erie, Pa. (Sennett). Other spring dates are: Magdalena Bay, Lower California, March 12, 1889 (Bryant); Monterey, Calif., April 17, 1903; Vancouver Island, British Columbia, April 28, 1894 (Kermode); Mount McKinley, Alaska, May 17, 1908 (Sheldon); Kowak River, Alaska, May 30, 1899 (Grinnell); Pea and Bodie islands, North Carolina, April 25, 1905 (Bishop); Lincoln, Nebr., April 27, 1900 (Wolcott); southern Ontario, average of six years May 18, earliest May 8, 1885 (Garnier); Melville Peninsula, May 31, 1882 (Parry); Wellington Channel, June 6, 1851 (Greely). The species was taken in Cuba as late as May 22, 1900 (Palmer and Riley); southern Florida, May 25, 1886 (Scott); from New Jersey to the Great Lakes it remains regularly to the first week in June-latest Oberlin, Ohio, June 17, 1904 (Jones); latest Worth, Ill., June 20, 1894 (Woodruff); and along the coast of Maine nonbreeders occur all summer (Knight). 
Eggs have been taken at Grand Manan, New Brunswick, June 21, 1875 (Cheney); James Bay, June 18, 1896 (Macoun); Cape Fullerton, June 28, 1904 (Eifrig); Fort Anderson, June 11, 1863 (MacFarlane); Fort Yukon, Alaska, June 2, 1862 (Lockhart); Lake Marsh, Yukon, just hatched, July 2, 1899 (Bishop).

Fall migration.-At one of the most southern breeding places, near York Factory, Keewatin, in 1900, the most advanced young were still in the downy stage July 10 (Preble), and yet by this time the species is already in full fall migration, and the earliest individuals have appeared several hundred miles south of the breeding range: Toronto, Ontario, July 5, 1890 (Fleming); Rhode Island, July 6 (Howe and Sturtevant); Coronado de Terraba, Costa Rica, July 3, 1907 (Carriker); Margarita Island, off the coast of Venezuela, July 7, 1895 (Robinson). The regular fall migration is about a month later: Sitka, Alaska, common after July 25, 1896 (Grinnell); Prince Edward Island, average of three years August 13 (Bain); Long Island, New York, average of seven years August 6, earliest July 17, 1905 (Latham); Grenada, West Indies, August 24, 1881 (Wells); Santa Catarina, Brazil, August 4 (Sharpe).

Though most semipalmated plover migrate early, a few stay until freezing weather: Ottawa, Ontario, average of five years September 19, latest September 29, 1885 (White); Prince of Wales Sound, Ungava, latest September 25, 1886 (Payne); Prince Edward Island, average of three years, October 13 (Bain); Erie, Pa., rare after October 1, latest November 2, 1901 (Todd); Point Pelee, Ontario, October 29, 1905 (Taverner and Swales); Grinnell, Iowa, October 22, 1886 (Jones); Los Angeles County, Calif., October 17, 1894 (Grinnell).

Ringed Plover. Agralitis hiaticula (Linn.).

Both coasts of Greenland are included in the breeding range of the ringed plover, from the southern end to Sabine Island (Scoresby) on the east coast and to McCormick Bay (Schalow) on the west. Across Smith Sound from this latter place and one degree farther north, at Buchanan Bay, Ellesmere Island, latitude $78^{\circ} 48^{\prime}$ (Feilden) is the farthest north the species has been found in the Western Hemisphere, though north of Europe it has been taken at $83^{\circ}$ latitude. On the American side it breeds south to Cumberland Sound (Kumlien); also south to central Europe and Turkestan, and east to the New Siberian Islands, and occurs casually east to the Chuckchi Peninsula. The winter is spent from the shores of the Mediterranean to southern Africa and rarely to northwestern India. It has wandered to Chile (Sharpe), and to Barbados, September 10, 1888 (Feilden). The first arrived at Cumberland Sound in 1878 about the middle of June (Kumlien).

Little Ringed Plover. Fgialitis dubia (Scop.).

The claim of the little ringed plover to a place among North American birds is rather slight. A specimen is supposed to have been taken on 
the coast of Alaska (Harting), and one is recorded from San Francisco, Calif. (Ridgway). In each case the bird was far from home, for the breeding grounds of the species are in southern Europe, central Asia, and north to about $60^{\circ}$ latitude. The species winters in the northern half of Africa, and in Asia south to India, and the Malay Archipelago.

\section{Piping Plover. Egralitis meloda (Ord).}

Breeding range.-The northern limit of the piping plover's breeding range is in Nova Scotia (Bryant), the Magdalen Islands in the Gulf of St. Lawrence (Bishop), southern Ontario (Saunders), central Manitoba (Bendire), southern Saskatchewan (Macoun), and probably southwestern Keewatin (King). It is very local in its distribution during the breeding season, and is unknown over most of the district mentioned above. Formerly it nested on the coast of Virginia at Cobbs Island (Kirkwood), and was fairly common as a breeder on the New Jersey coast (Scott). Now it is rare as a breeder anywhere on the Atlantic coast south of Nova Scotia, though still nesting at a few localities south to southern New Jersey (Stone). In the interior it nests as far south as Erie, Pa. (Todd); the lake shore in northern Ohio (Jones); near Lake Michigan in northwestern Indiana (Woodruff); and west to central Nebraska (Bruner, Wolcott, and Swenk).

Winter range.-The coast of Texas (Sennett) and the coasts of Florida (Scott) and Georgia (Worthington) constitute the principal winter home of this species. Indeed, it is probable that records at other places represent stragglers. The West Indies are commonly included in the winter range, but the species seems to be only casual in migration south of the United States. It was taken once in Porto Rico in August (Gundlach); Jamaica in November (Gosse); a few in Cuba in April of a single year (Gundlach); several on three islands of the Bahamas in May (Bangs) and July (Bonhite); three individuals in the Bermudas in the fall (Reid). It has occurred occasionally on the New Jersey coast in winter (Stone).

Spring migration.-Dates of spring arrival are very irregular. The average date on Long Island, New York, is April 7; earliest March 24, 1884 (Dutcher); eastern Massachusetts, average April 12, earliest March 26, 1893 (Mackay); southern Ontario, average May 16, earliest May 1, 1891 (Fleming). Some other dates of arrival are: Cumberland, Ga., March 10, 1902 (Helme); near Newport, R. I., March 24, 1903 (King); Erie, Pa., April 16, 1900 (Todd); Oberlin, Ohio, May 13, 1907 (Jones); Sioux City, Iowa, May 8, 1904 (Rich); Gibbon, Nebr., May 4, 1888 (Thatcher); Indian Head, Saskatchewan, May 16, 1892 (Macoun). Thus, in general, migration up the Mississippi Valley is much later than at corresponding latitudes on the 
Atlantic coast. Stragglers were noted at Cheyenne, Wyo., May 30, 1892 (Bond), Julesburg, Colo., May 17, 1899 (Dawson), and Natashquan, Labrador, May 31, 1909 (Townsend_and Bent).

Eggs have been taken at Big Charity Island, Michigan, May 20, 1903 (Arnold); Erie, Pa., May 24, 1900 (Todd); Long Beach, New Jersey, June 12, 1877 (Scott); Magdalen Island, June 16, 1897; Cedar Point, Ohio, June 26, 1903 (Jones); Miller, Ind., June 13, 1905 (Butler); Miner County, S. Dak., June 5, 1891 (Patton); near Indian Head, Saskatchewan, June 18, 1892 (Macoun). Downy young were taken July 21, 1906, at Big Stick Lake, southwestern Saskatchewan (Bent).

Fall migration.-The first was seen on the coast of North Carolina July 14, 1904 (Bishop); and at Fernandina, Fla., August 3, 1906 (Worthington). It was taken at Corpus Christi, Tex., all through July, 1887 (Sennett); but these may have been nonbreeders that summered on the coast. In general the species migrates so early that it is seldom found north of its winter home after August. Late dates are: Long Island, New York, August 30, 1889 (Scott); eastern Massachusetts, August 26, 1888 (Miller); Erie, Pa., September 26, 1902 (Todd).

Snowy Plover. Algialitis nivosa Cass.

Breeding range.-The sea coasts and the shores of the larger lakes of western United States constitute the principal breeding grounds of the snowy plover. The species nests at least as far north as Pescadero, Calif. (Willard); Humboldt River, Nevada (Hanna); Salt Lake, Utah (Ridgway); Comanche County, Kans. (Goss); and on the coast of Texas (Sennett). It is extremely local in the interior. It breeds south at least to Corpus Christi, Tex. (Sennett), and probably along the northern third of the western coast of Lower California (Belding).

Winter range.-It winters in Chile south at least to Calbuco, latitude $41^{\circ} \mathrm{S}$. (Schalow), and thence north in Peru (Sclater and Salvin), Guatemala (Salvin), and Mexico (Belding) to the coast of California at Santa Barbara (Keck). On the Atlantic side it winters as far north as Aransas Bay, Texas (Sennett).

Migration range. - Outside of the regular winter and summer homes, the species has been taken once in Brazil (specimen in United States National Museum); Margarita Island, off the coast of Venezuela, July 2, 1895 (Robinson); Guantanamo, Cuba, July, 1858 (Gundlach); Long Island, Bahamas, July 16, 1903 (Riley); Celestun, .Yucatan, April 12, 1865 (Schott); Whitfield, Fla., May 5, 1903 (Worthington); Bay St. Louis, Miss., September 19-20, 1899 (Allison); Toronto, Ontario, twice (Fleming); Lincoln, Nebr., May 17, 1903 (Swenk); Cheyenne, Wyo., once (Bond); Newport, Oreg., March 24, 1906 (Shaw); Grays Harbor, Washington, September 3, 1899 (Dawson). Spring migration.-The snowy plover was seen in Comanche County, Kans., May 12, 1887 (Goss), and at San Francisco, Calif., 
April 8, 1857 (Hepburn). The species has been taken at Cavanche, Chile, in May (Schalow), and at Coquimbo, Chile, in June (Sharpe). It may prove to be resident in Chile.

Eggs have been taken in Los Angeles County, Calif., April 25, 1899 (Robertson), and young, May 1, 1897 (Grinnell); also eggs at Santa Cruz, Calif., April 16, 1873 (Cooper). In southern Kansas the eggs are laid in late May (Goss).

Fall migration.-Fall migrants have been .recorded in September from Guatemala (Salvin), and in October from the southern limit of the range in Chile (Schalow). The species has been taken at San Francisco as late as November 1, 1898 (Hornung).

Mongolian Plover. Z2Eialitis mongola (Pall.).

In the summer of 1849 Captain Moore of the Plover in his search for Sir John Franklin touched at the Choris Peninsula, Alaska, and while there secured two specimens of the Mongolian plover-the first and only individuals ever taken in North America. The breeding range of the species is on the opposite side of Bering Sea; on the Commander Islands, and in northeastern Siberia. It migrates through Japan and China, and winters from the Philippines to Australia.

[Azara Ring Plover. Egialitis collaris (Vieill.).

The Azara ring plover is the only true shorebird found in Central America that does not range north to the United States. It has a wide distribution in South America, south to Argentina, extends north to southern Mexico, and has been taken once on Grenada, West Indies.]

\section{Wilson Plover. Óchthodromus wilsonius (Ord).}

Breeding range.-The Wilson plover is found in summer throughout the northern Bahamas (Bonhote) and along the Gulf coast of the United States from Florida (Scott) to Texas (Merrill), and breeds along the Atlantic coast at the present time as far north as the islands off the southeastern coast of Virginia (Dutcher); many years ago it bred occasionally on the New Jersey coast (Wilson). The summer status of the species on the Pacific coast of Lower California is not yet definitely settled. It was found common at Abreojos Point, June 17, 1897 (Kaeding), but whether or not it was breeding was not determined:

Winter range.-The winter range is not known with certainty, because the West Indies are occupied by a resident subspecies, mufinuchus, and sufficient material has not yet been accumulated to determine the relative areas occupied by the two forms in winter. The northern form winters as far north as southern Florida-formerly northern Florida (Scott); the coast of southern Texas (Merrill); Guaymas, Sonora (Nelson); and La Paz, Lower California (Belding). Thence it ranges south to the Pacific coast of Guatemala (Salvin).

Spring migration.-Dates of arrival on the Atlantic coast are: Amelia Island, Florida, April 2, 1906 (Worthington); Darien, Ga., 
March 19, 1890 (Worthington); Cumberland Island, Georgia, March 18, 1902 (Helme); Frogmore, S. C., March 26, 1886, and March 20, 1888 (Hoxie); Fort Macon, N. C., April 15, 1869 (Coues). The species has wandered north on the coast several times to Long Island (Dutcher), once to Connecticut (Purdie), once to Massachusetts (Coues), and even to Nova Scotia (Goss). The only record for the Pacific coast of the United States is that of the single bird taken June 29, 1894, at Pacific Beach, California (Ingersoll).

Eggs have been taken at Sarasota Bay, Florida, April 8 (Moore); coast of Georgia, April 29 (Bailey); Corpus Chrïsti, Tex., April 25 (Chapman); Cobbs Island, Virginia, May 7 (Oates).

[Rufous-naped Plover. Ochthodromus wilsonius rufinuchus (Ridgw.).

The principal home of the subspecies rufous-naped plover is the Greater Antilles, whence it spreads to the neighboring coasts of British Honduras and Guatemala; probably also to Yucatan. It breeds also in northern South America on the coast of Colombia, Venezuela, and Guiana. While some individuals remain all the year on the breeding grounds, others migrate a short distance to several of the islands of the Lesser Antilles and to Brazil as far south as Bahia. It is probably this form that occurs on the coast of Ecuador and Peru, but from lack of specimens this point is not settled.]

\section{Mountain Plover. Podasocys montanus (Towns.).}

Breeding range.-The mountain plover seems to be confined in summer to the United States, but closely approaches the boundaries, both north and south. In 1874 it was found breeding and not uncommon on the Frenchman River in Montana (Coues), not far from the Canadian boundary, and on Milk River, Montana (Coues), right at the line, but so far has not been recorded anywhere in Canada. It breeds south to northern New Mexico (Henshaw); east to northwestern Texas (Bailey), western Kansas (Fisher), and western Nebraska (Bruner), west to Sun River, Montana (Dutcher), Fort Bridger, Wyo. (Drexler), Del Norte, Colo. (Hill and Orth), and San Miguel County, New Mexico (Mitchell).

Winter range.-This species winters from northern California (Cooper), southern Arizona (Osgood), and San Antonio, Tex. (Beckham), south to Zacatecas, Mexico (Sharpe), and La Paz, Lower California (Sharpe). It is one of the few species that winters farther west than it breeds.

Migration range.-The more eastern individuals of this species probably follow the usual north and south migration route, keeping to the plains east of the foothills of the Rocky Mountains, but some of the more western individuals take a very peculiar course in migration. The species is a tolerably common migrant at Marysville in northern California (Belding), arriving in November. Whence come these November birds? The nearest point of the breeding range is northwestern Montana in the vicinity of Great Falls (Williams). To reach Marysville from Great. Falls the plover must pass through 
Idaho and either Oregon or Nevada, but in these three States it is unknown, and seems not to be recorded from Utah. So the birds that visit California are separated from the nearest known habitat of the species by a zone about 600 miles wide and containing two ranges of high mountains.

Spring migration.-The mountain plover is among the early migrant shorebirds. It arrived on the average at Beloit, Colo., March 26, earliest March 23, 1890 (Hoskins); Loveland, Colo., March 18, 1887 (Smith).

Eggs have been taken at Fort Lyon, Colo., June 9, 1886 (Thorne); San Luis Valley, Colo., June 10, 1873 (Henshaw); young just hatched at Terry, Mont., June 15, 1898 (Cameron); young at Colby, Kans., June 28, 1893 (Fisher); eggs near North Platte, Nebr., July 8, 1859 (Suckley).

Fall migration.-The first was seen at Corpus Christi, Tex., July 25, 1887 (Sennett); Pecos City, Tex., August 1, 1903 (Ligon). Quite a party of them was seen at James Island, Florida, July 20 to August 1, 1901 (Williams), but they were probably only stragglers. The last one noted in 1890 at Beloit, Colo., was on October 15 (Hoskins).

Surf Bird. Aphriza virgata (Gmel.).

The breeding range of the surf bird is unknown, for the bird has never been encountered in its summer home. It goes north along the Pacific coast of the United States in spring, and has been traced all along the coast to the Kowak River, Alaska, where it arrived May 29, 1899 (Grinnell). Then it disappears and is not seen again until on its way south the latter part of July. The natives say it breeds on the mountains a few miles back from the coast.

The surf bird winters in Chile, as far south as the Strait of Magellan (Sharpe), and is known in migration on the coasts of Peru (Tschudi), Ecuador (Hartert), Mexico (Xantus), and Lower California (Kaeding). It arrived at Newport, Oreg., April 25, 1895; April 27, 1897; May 3, 1899; April 27, 1900; average of the four years April 28 (Bretherton). Agreeing well with this date is its appearance at San Geronimo Island, Lower California, March 15, 1897 (Kaeding); and the date already given of May 29 at Kowak River, Alaska (Grinnell). An extra early date is March 8, 1859, at Puget Sound, Washington (Kennerly). The latest recorded date at the Strait of Magellan is March 3, 1879 (Sharpe); the species was common at Abreojos Point, Lower California, April 19, 1897 (Kaeding); a belated bird was taken on the Farallon Islands, Calif., June 3, 1903 (Kaeding). Several appeared in fall migration at Sitka, Alaska, July 21 (Grinnell); Newport, Oreg., July 24, 1900 (Bretherton); Monterey Bay, Calif., August 3, 1894 (Loomis); Vaqueria, Ecuador, September 16, 1901 (Hartert). The species has been noted at St. Michael, Alaska, until the first of October (Nelson), and at Berkeley, Calif., as late as October 24, 1888 (Palmer). 
Turnstone. Arenaria interpres (Linn.).

Breeding range.- The turnstone inhabits nearly the whole of the Eastern Hemisphere and a small part of the Western. It breeds along the whole Arctic coast of Europe and Asia and south to Japan and the islands in the Baltic Sea. It ranges eastward across Bering Strait at least to Point Barrow, Alaska (Stone), and breeds south to the mouth of the Yukon (Nelson) and on the islands of St. Lawrence (Nelson) and St. Matthew (Elliott) in Bering Sea. Its range to the northeastward in North America has not yet been definitely settled. Two specimens from the west coast of central Greenland have been identified by W. Palmer as interpres. No specimens were examined by him from any point between Greenland and the Anderson River, Mackenzie; the specimens from this latter place are certainly morinella. Where the dividing line between the two forms runs is not certain, but since the birds of eastern Ungava are morinella, it is probable that this is the form occurring on the islands near the Arctic coast of North America and equally probable that the records on the islands northwest of Greenland should be referred to interpres. The species has been recorded along the whole west coast of Greenland, and was found breeding at Disco Bay (Kumlien) and on the eastern and northern coasts of Ellesmere Island almost to latitude $83^{\circ}$ (Feilden). The turnstone, therefore, is one of the most northern breeding of all birds. On the eastern coast of Greenland it ranges at least as far north as Sabine Island, latitude $74^{\circ}$ (Winge).

Winter range.-The species winters on the coasts of nearly the whole of the Eastern Hemisphere from Europe and Asia to southern Africa, Australia, and the islands of the Pacific, Indian, and eastern Atlantic oceans.

Spring migration.-The species arrived in the Aleutians at Unalaska May 19, 1890 (Palmer). As it winters in Hawaii (Henshaw), and is not known on the coast of the mainland south of Alaska, it is practically certain that these Unalaska birds make the journey of 2,000 miles in a single flight from Hawaii to the Aleutians. Other dates of spring arrival are: Mouth of the Yukon, May 19, 1879 (Nelson); Nulato, Alaska, May 23, 1868 (Dall); Point Barrow, Alaska, June 12, 1882 (Murdoch), June 12, 1883 (Murdoch), and May 29, 1898 (Stone). The dates of arrival northwest of Greenland are May 27, 1876, at Cape Henry (Hart), and June 2, 1883, at Cape Baird (Greely), each near latitude $82^{\circ}$.

Eggs were taken July 30, 1876, at Discovery Bay, Ellesmere Island, $81^{\circ} 40^{\prime} \mathrm{N}$. (Hart), and young were already on the wing July 9, 1883, at Fort Conger (Greely), a few miles distant. Downy young were taken June 4, 1898, at Point Barrow, Alaska (Stone).

Fall migration.- The first arrived on the Pribilof Islands July 2 (Elliott), and after the middle of the month were abundant. The 
last ones noted were: Depot Point, Ellesmere Island, latitude $82^{\circ}$ $45^{\prime}$ N., September 11, 1875 (Feilden); Point Barrow, Alaska, August 29, 1882 (Murdoch), and September 4, 1897 (Stone); Nushagak, Alaska, September 21, 1902 (Osgood). A specimen is reported taken September 8, 1904, at Pacific Beach, Calif. (Bishop), and one September 8, 1892, on Monomoy Island, Massachusetts (Bishop).

Ruddy Turnstone. Arenaria interpres morinella (Linn.).

Breeding range.-Undoubted breeding records of the ruddy turnstone are very rare. It nested on the Lower Anderson and Franklin Bay (MacFarlane), and specimens of the breeding birds have been identified as morinella. Some form of the turnstone, probably morinella, breeds on Melville Island (Sabine), on Melville Peninsula (Parry), and at Bellot Strait (Walker), but its identity has yet to be determined by the examination of specimens.

Winter range.-The turnstone of the Western Hemisphere ranges south in winter to central Chile-at least to Talcahuano (Sharpe) and probably to Valdivia (Boeck)-and to Sao Paulo in Brazil (Ihering). It winters on the coasts of northern South America, in the West Indies, Central America, Mexico, and north to the coast of South Carolina (Coues), Louisiana (Beyer), Texas (Merrill), and in California at least as far north as San Francisco (Mailliard).

Spring migration.-The turnstone, notwithstanding it winters so far north, is a late migrant. The probable explanation is that its breeding grounds in the far north are not ready for occupancy until nearly midsummer. It was seen May 7, 1906, on Pea and Bodie islands, North Carolina (Bishop). The average date of arrival on Long Island, New York, is May 16, earliest May 12, 1897 (Scott); eastern Massachusetts, May 5, earliest May 1, 1892 (Mackay); Erie, Pa., May 24, 1893 (Todd). It appears to be rare in spring north of Maine on the Atlantic coast.

The species is rare in the interior of the United States, but has been noted a few times in nearly every State east of the Rocky Mountains. Some dates of arrival are: Starke County, Ind., May 20, 1888 (Butler); Oberlin, Ohio, May 16, 1901 (Jones); southern Ontario, average May 27, earliest May 24, 1900 (Nash); Leech Lake, Minn., May 24, 1903 (Currier); Indian Head, Saskatchewan, May 15, 1892 (Macoun); Fort Chipewyan, Alberta, May 25, 1901 (Preble); Fort Resolution, Mackenzie, June 1, 1860 (Kennicott); Fort Simpson, Mackenzie, May 29, 1904 (Preble); Fort Anderson, Mackenzie, June 10, 1864 (MacFarlane); Winter Island, Melville Peninsula, June 14, 1822 (Richardson).

It was found off the coast of Venezuela, July 2, 1892 (Hartert), July 7, 1895 (Robinson), and early July, 1901. (Clark). A few are said to remain all summer on Carriacou Island, West Indies (Wells). $52928^{\circ}-$ Bull. $35-10-7$ 
The migrant birds remain in numbers far south of the breeding grounds until early June: Jamaica, June 12, 1863 (Field); Arcos Keys, Yucatan, June 6, 1900 (Nelson and Goldman); Key West, Fla., June 14, 1888 (Scott); Long Island, New York, average June 4, latest June 9, 1905 (Latham); Toronto, Ontario, June 17, 1894 (Fleming).

Fall migration.--The southward movement must begin in July, for by early August migrants have appeared over much of the coasts of the United States. Some dates of fall arrival are: Monomoy Island, Massachusetts,July 27, 1886(Cahoon); Long Island, New York, average August 5, earliest July 27, 1892 (Scott); Monterey, Calif., July 18, 1892 (Loomis); Fort Churchill, Keewatin, July 30, 1900 (Preble); common at Corpus Christi, Tex., after July 1, 1887 (Sennett); Toronto, Ontario, July 30, 1898 (Nash); Henley Harbor, Ungava, August 20, 1860 (Coues); Mingan Island, Gulf of St. Lawrence, August 16, 1887 (Palmer); Montreal, Canada, August 17, 1891 (Wintle); Erie, Pa., August 24, 1889 (Sennett); Punta Rassa, Fla., August 2, 1886 (Scott); San Mateo, Tehuantepec, August 9, 1869 (Sumichrast); Jamaica, August 13, 1863 (March); Bermudas, August 3, 1874 (Reid); Talcahuano, Chile, September 9, 1879 (Sharpe). Dates of the last seen are: York Factory, August 26, 1900 (Preble); eastern Massachusetts, October 9, 1889 (Miller); Erie, Pa., September 25, 1900 (Todd); Long Island, New York, September 20, 1889 (Scott), accidental November 24, 1887 (Scott).

\section{Black Turnstone. Arenaria melanocephala (Vig.).}

Breeding range.-The black turnstone breeds commonly on the coast of Alaska near the mouth of the Yukon (Nelson) and up the Yukon as far as Nulato (Dall and Bannister). It breeds less commonly north to Kotzebue Sound (Townsend) and south to Nushagak (McKay). It has been seen on the eastern side of Bering Strait nearly to Point Barrow, Alaska (Nelson), and on the western side to Herald Island (Nelson), off the northern coast of Siberia, but it is not yet known to breed in either of these localities.

Winter range.-The greater number winter on the coast of Lower California, south to Magdalena Bay (Anthony). The species is not rare in.winter on the California coast as far north as San Francisco (Mailliard), and a few have been known to winter at the Strait of Juan de Fuca (Suckley). It may winter occasionally even in southeastern Alaska, for the National Museum has a specimen collected February 2, 1897, at Howkan Island, Alaska (Cantwell).

Spring migration.-The species arrived at St. Michael, Alaska, about the middle of May (Nelson) and at Nulato, Alaska, May 16, 1867; and May 23, 1868 (Dall and Bannister).

Fall migration.-The black turnstone occurs on the Pacific coast from British Columbia (Kermode) to southern California throughout 
the entire summer, but is not known to breed (Grinnell). The presence of these nonbreeding birds prevents accurate observations on the arrival of the first migrants from the north, but it seems probable that early in July some appear on the coast of central California, and the species-was seen August 6, 1902, on the Coronados Islands, Lower California (Grinnell and Daggett). The last leave the delta of the Yukon about the middle of September (Nelson) and Nushagak, Alaska, September 22, 1902 (Osgood).

\section{Furopean Oyster-catcher. Hæmatopus ostralegus Linn.}

The southwestern coast of Greenland has been visited several times by the European oyster-catcher, once as far north as Godthaab, latitude $64^{\circ}$ (Winge). It is not certainly known to breed there, but its breeding range extends from Iceland and western Europe to Turkestan and from southern Europe to the Arctic coast. It winters from central Europe to central Africa and to western India.

Oyster-catcher. Hæmatopus palliatus Temm.

The oyster-catcher ranges south to Santa Catharina, southern Brazil (Sharpe), and to Arauco in central Chile (Sharpe). It occurs throughout most of the West Indies and Central America and along both coasts of Mexico-on the west coast north to the Tres Marias (Nelson). On the Atlantic coast it is resident as far north as South Carolina (Coues), and formerly was common on the Virginia coast (Bailey), and bred at Great Egg Harbor, New Jersey (Wilson). There are a few records for the coast of Massachusetts (Brewer) and one at Grand Manan, New Brunswick (Boardman). At the present time it is rare or accidental north of Virginia, though a flock of about 20 was seen July 20, 1907, at Digby, Nova Scotia, by W. H. Osgood, of the Biological Survey. It is still resident on the coasts of Louisiana and Texas.

It breeds throughout most of its regular range and probably most individuals are nonmigratory. The few that migrate along the southern Atlantic coast perform their short migratiơns principally in March. Eggs were taken at Corpus Christi, Tex., in 1882, April 6 to 27 (Goss). Eggs are recorded in Florida from April 10 to May 6; and they have been collected on the islands of the Virginia coast from May 3 to July 12.

\section{Frazar Oyster-catcher. Hæmatopus frazari Brewst.}

The Frazar oyster-catcher is apparently nonmigratory, and is the common breeding bird of both coasts of southern Lower California, whence it ranges along the whole west coast of the peninsula and north to San Diego (Cooper), the coast of Ventura County (Evermann), and the Santa Barbara Islands (Cooper), casual on the coast of Sinaloa, Mexico (Nelson and Goldman). In the northern part of its range it is not so numerous as bachmani, whose range overlaps that of 
frazari for about a thousand miles from Ventura County, Calif., to Abreojos Point, Lower California (Kaeding).

Black Oyster-catcher. Hæmatopus bachmani Aud.

The coast of western North America is the home of the black oyster-catcher, and it breeds locally throughout its range from Abreojos Point, Lower California (Kaeding), north. to Prince William Sound, Alaska (Grinnell), and west to Attu Island (Turner) at the western end of the Aleutian chain. It winters from the coast of southern British Columbia (Fannin) southward. The short migration is performed during May, and the eggs are deposited at the northern end of the range from the middle to the latter part of June. This is also the time at which eggs are most commonly found at the extreme southern end of the summer home. Downy young were taken June 17, 1900, on Queen Charlotte Islands, British Columbia (Osgood).

[Stone Curlew. CEdicnemus bistriatus (Wagler).

The stone curlew is somewhat generally distributed throughout the lower portions of Central America from Panama to southern Mexico, and also ranges into South America north of the Amazon. It is nonmigratory.]

Mexican Jacana. Jacana spinosa (Linn.).

The Mexican jacana was described originally from Cartagena, Colombia, and as that remains still the only record for the country, the ascription to this locality was probably an error. The speries is known from Divala, Panama (Bangs), and thence north $c$ i the Pacific side to Mazatlan, Mexico (Lawrence), and on the Gulf side to the mouth of the Rio Grande (Merrill). It is recorded from Porto Rico (Gundlach), Haiti (Ritter), Jamaica (Denny), and Cuba (Vigors)-rare in the first three and common in Cuba. One was taken October, 1899, at Lake Okeechobee, Florida (Mearns)-first record for the State. The species is resident throughout its regular range and breeds for about half the year from March to September.

[Black Jacana. Parra nigra (Gmel.).

The black jacana is a nonmigratory species inhabiting northern South America and occurring in southern Panama.]

[Colombian Jacana. Parra melanopygia (Sclater).

A nonmigratory South American species found principally in Colombia, but extending north to Panama.] 


e .

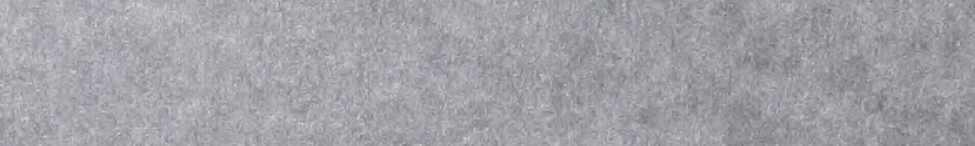

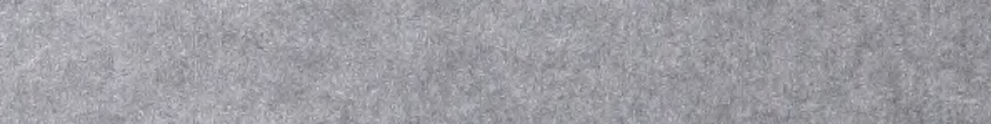

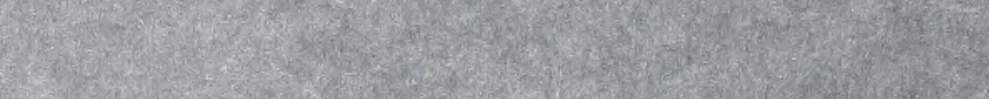

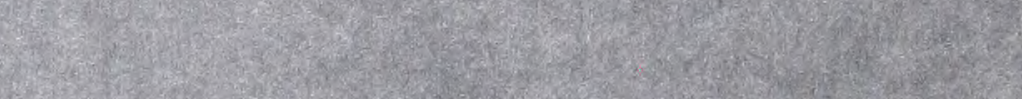

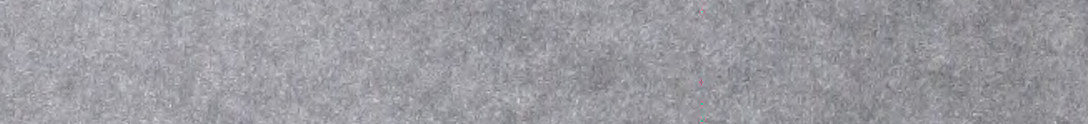

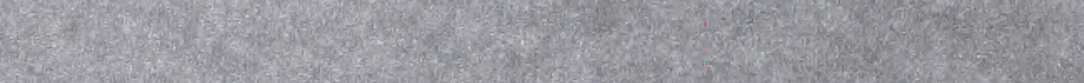

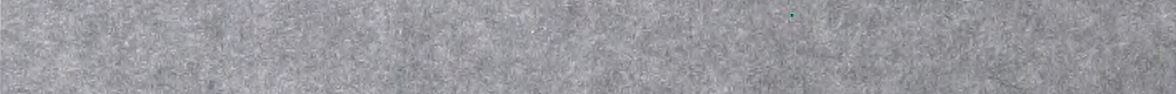

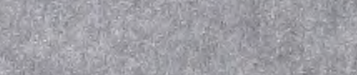

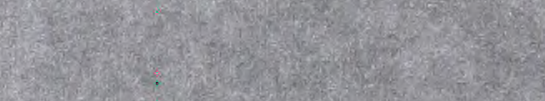

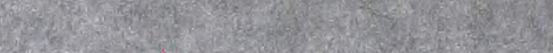

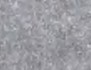
150. 